FERNANDO GOMES

\title{
A SÍNTESE DE COENZIMA Q E A ESTABILIDADE DE DNA MITOCONDRIAL EM Saccharomyces cerevisiae
}

Dissertação apresentada ao Programa de Pós-Graduação em Microbiologia do Instituto de Ciências Biomédicas da Universidade de São Paulo, para obtenção do título de Mestre em Ciências.

São Paulo

2012 
FERNANDO GOMES

\section{A síntese de coenzima $Q$ e a estabilidade de DNA mitocondrial em Saccharomyces cerevisiae}

Dissertação apresentada ao Programa de Pós-Graduação em Microbiologia do Instituto de Ciências Biomédicas da Universidade de São Paulo, para obtenção do título de Mestre em Ciências.

Área de Concentração: Microbiologia

Orientador: Prof. Dr. Mario Henrique de Barros

Versão corrigida. Versão original eletrônica encontra-se disponível tanto na Biblioteca do ICB quanto na Biblioteca de Teses e Dissertações da USP (BDTD) 
DADOS DE CATALOGAÇÃO NA PUBLICAÇÃO (CIP)

Serviço de Biblioteca e Informação Biomédica do

Instituto de Ciências Biomédicas da Universidade de São Paulo

reprodução não autorizada pelo autor

\section{Gomes, Fernando.}

A síntese de coenzima $Q$ e a estabilidade de DNA mitocondrial em Saccharomyces cerevisiae. / Fernando Gomes. -- São Paulo, 2012.

Orientador: Prof. Dr. Mário Henrique de Barros.

Dissertação (Mestrado) - Universidade de São Paulo. Instituto de Ciências Biomédicas. Departamento de Microbiologia. Área de concentração: Microbiologia. Linha de pesquisa: Biogênese Mitocondrial

Versão do título para o inglês: The synthesis of coenzyme $Q$ and stability of mitochondrial DNA in Saccharomyces cerevisiae.

1. Saccharomyces 2. Mitocôndrias 3. Respiração celular I. Barros, Mário Henrique de II. Universidade de São Paulo. Instituto de Ciências Biomédicas. Programa de Pós-Graduação em Microbiologia III. Título. 
Candidato(a):

Título da Dissertação:

Orientador(a):
Fernando Gomes.

A síntese de coenzima $Q$ e a estabilidade de DNA mitocondrial em Saccharomyces cerevisiae.

A Comissão Julgadora dos trabalhos de Defesa da Dissertação de Mestrado, em sessão pública realizada a , considerou
( ) Aprovado(a)
( ) Reprovado(a)

Examinador(a): Assinatura:

Nome:

Instituição:

Examinador(a): Assinatura:

Nome:

Instituição:

Presidente: Assinatura:

Nome:

Instituição: 


\section{CERTIFICADO DE ISENÇÃO}

Certificamos que o Protocolo CEP-ICB No 370/10 referente ao projeto intitulado: “ $A$ síntese de coenzima $Q$ e a estabilidade de DNAmitocondrial em Saccharomyces cerevisiae" sob a responsabilidade de Fernando Gomes, foi analisado na presente data pela CEUA - COMISSÃO DE ÉTICA NO USO DE ANIMAIS e pela CEPSH- COMISSÃO DE ÉTICA EM PESQUISA COM SERES HUMANOS, tendo sido deliberado que o referido projeto não envolve manipulação animal ou humana que justifique uma aprovação quanto aos princípios éticos exigidos por ambas as Comissões.

São Paulo, 20 de abril de 2010.

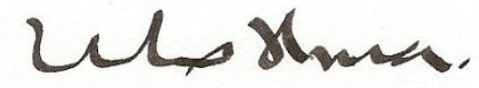

PROF. DR. WOTHAN TAVARES DE LIMA Coordenador da CEUA - ICB/USP

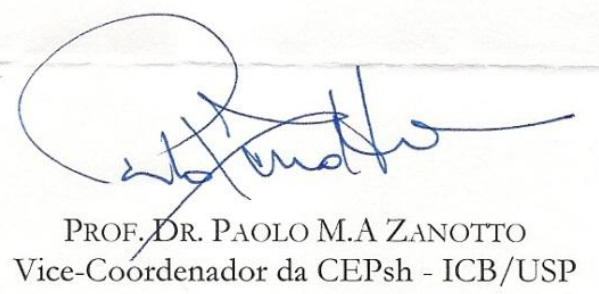


Aos meus pais Valter e Maria, que sempre me amaram e me incentivaram em todas as etapas de minha vida.

A minha amada e eterna companheira, Helena Gabriela, o grande e único amor da minha vida. Te amo! 


\section{AGRADECIMENTOS}

Ao meu orientador, professor Mário Henrique de Barros, por quem tenho grande admiração e respeito pela sua trajetória acadêmica. Obrigado por ter me aceitado em seu laboratório e depositado em mim a confiança de ser o seu primeiro aluno de mestrado.

A professora Alicia Kowaltowski, por permitir utilizar os equipamentos e reagentes de seu laboratório, os quais foram fundamentais para 0 desenvolvimento desse trabalho.

Ao meu quase co-orientador, Erich Birelli Tahaha, que tanto me ajudou no planejamento e na execução de grande parte dos experimentos. Parceiro de corridas me incentivou a entrar para o mundo do atletismo.

Ao grande amigo Cleverson Busso que me acolheu como parceiro de laboratório e ajudou-me a conseguir o auxílio moradia no CRUSP. Além de um amigo, um verdadeiro exemplo de honestidade e bondade.

A Raquel Fonseca Guedes, que apesar de conhecê-la a pouco tempo, já a considero uma das minhas melhores amigas. Obrigado por todo o carinho e atenção oferecidos durante o período de convivência no laboratório.

Ao professor José Ribamar Ferreira Júnior, um homem de um conhecimento inestimável. Obrigado pelos conselhos e ajuda no planejamento dos experimentos.

A minha segunda mãe, Viviane Cristina Baptista, que sempre demonstrou um enorme carinho por mim desde o primeiro dia de laboratório. Obrigado por me ajudar com os experimentos, principalmente com a dissecação das tétrades.

Aos colegas de laboratório e do ICB, muitos dos quais já não estão presentes: Mariana, Enyd, Norton, Janaína Leme, Janaína Paulela, Tatiana, Adolfo Tadeu, Juan, Julian, Felipe e muitos outros que não caberiam aqui.

Aos colegas do CRUSP que me acolheram durante esses dois anos e se mostraram verdadeiros amigos. Otto, Elaine, Josenilson e Marlio.

Ao meu grande amor, Helena Gabriela Turano, que entrou na minha vida e deu um novo sentido a ela. Te amo muito. Obrigado por deixar fazer parte de sua família e poder compartilhar as alegrias com o seu filho Enzo.

A toda a minha família que sempre me amou a acreditou na minha formação. Amo vocês.

A Deus que tanto nos ama e nunca nos abandona. 
"Nas grandes batalhas da vida, o primeiro passo para a vitória é o desejo de vencer" Mahatma Gandhi 


\section{RESUMO}

GOMES, F. A síntese de coenzima $Q$ e a estabilidade de DNA mitocondrial em Saccharomyces cerevisiae. 2012. 76 f. Dissertação (Mestrado em Microbiologia) - Instituto de Ciências Biomédicas, Universidade de São Paulo, São Paulo, 2012.

A manutenção da integridade do DNA mitocondrial (mtDNA) é essencial para a função respiratória da mitocôndria. Mutantes respiratórios de Saccharomyces cerevisiae podem apresentar uma ampla variedade de instabilidade do mtDNA. Nós analisamos diferentes classes de mutantes e observamos uma elevada instabilidade nos mutantes que não possuem a coenzima $Q$ (CoQ) funcional. A CoQ é responsável pela transferência de elétrons do succinato e NADH desidrogenases para o complexo III da cadeia respiratória, podendo atuar, também, como um importante antioxidante celular. $\mathrm{O}$ objetivo desse trabalho foi correlacionar a presença de coenzima $Q$ funcional e seu estado redox com a estabilidade do mtDNA. Para alterar o estado redox do "pool" de CoQ, alteramos a expressão das diferentes NADH desidrogenases mitocondriais em linhagens de leveduras com diferentes deficiências no metabolismo da coenzima Q. No mutante $\Delta \operatorname{coq} 10$, que sintetiza $\mathrm{CoQ}$ não funcional, a inativação das $\mathrm{NADH}$ desidrogenases individuais Ndi1p e Nde1p, resultou numa menor instabilidade do mtDNA, acompanhada por uma diminuição na taxa de liberação de peróxido de hidrogênio $\left(\mathrm{H}_{2} \mathrm{O}_{2}\right)$. Por outro lado, a super-expressão de Nde1p aumentou a instabilidade do mutante $\Delta \operatorname{coq} 10$, assim como para a linhagem selvagem. A inativação das NADH desidrogenases individuais na linhagem $\Delta c o q 4$, deficiente na síntese da CoQ, não reduziu a instabilidade do mtDNA. Juntos, os resultados indicam que alterações no estado de oxido-redução da coenzima $Q$ influenciam a estabilidade do mtDNA, provavelmente através da produção de espécies reativas de oxigênio.

Palavras-chave: Saccharomyces cerevisiae, coenzima Q, DNA mitocondrial, espécies reativas de oxigênio. 


\begin{abstract}
GOMES, F. The synthesis of coenzyme $Q$ and stability of mitochondrial DNA in Saccharomyces cerevisiae. 2012. 76 f. Dissertation (M.Sc. Microbiology) Institute of Biomedical Sciences, University of São Paulo, São Paulo, 2012.

Maintenance of the integrity of DNA (mtDNA) mitochondrial is essential for mitochondrial respiratory function. Saccharomyces cerevisiae respiratory mutants can show a wide range of mtDNA instability. We analyze different classes of mutants and observed a higher instability among mutants lacking a functional coenzyme $Q$ (CoQ). CoQ is responsible for transfer of electrons from the succinate dehydrogenases and NADH dehydrogenases to complex III of the respiratory chain and is also an important cellular antioxidant. The aim of this study was to correlate the presence of functional coenzyme $Q$ and its redox state with the stability of mtDNA. To change the redox state of the "pool" of CoQ, we altered the expression of different mitochondrial NADH dehydrogenases in yeast strains with different defects in the metabolism of coenzyme Q. In $\Delta$ coq 10 mutant, which synthesizes CoQ nonfunctional, inactivation of individual NADH dehydrogenases Ndi1p Nde1p has shown a decreased mtDNA instability, which was accompanied by a decrement in the rate of hydrogen peroxide $\left(\mathrm{H}_{2} \mathrm{O}_{2}\right)$ release. Moreover, overexpression of Nde1p increased instability $\Delta$ coq10 mutant, as well as the wild type strain. The inactivation of individual NADH dehydrogenases in $\Delta$ coq4 strain which is deficient in the synthesis of $\mathrm{CoQ}$, did not reduce the instability of the mtDNA. All the results indicate that changes in the redox state of coenzyme $Q$ influence the stability of mtDNA, probably by the production of reactive oxygen species.
\end{abstract}

Keywords: Saccharomyces cerevisiae, coenzyme Q, mitochondrial DNA, reactive oxygen species. 


\section{LISTA DE ILUSTRAÇÕES}

Figura 1 - Representação esquemática da cadeia respiratória de Saccharomyces cerevisiae.

Figura 2 - Frequência de geração de colônias petites em diferentes mutantes respiratórios de $S$. cerevisiae.

Figura 3 - Medida do consumo de oxigênio das mitocôndrias isoladas dos mutantes das NADH desidrogenases.

Figura 4 - Propriedades de crescimento das linhagens WT, $\Delta$ coq10 e $\Delta c o q 4$, em combinação com a inativação das diferentes $\mathrm{NADH}$ desidrogenases mitocondriais

Figura 5 - Medidas da liberação de peróxido de hidrogênio $\left(\mathrm{H}_{2} \mathrm{O}_{2}\right)$ em mitocôndrias isoladas de diferentes linhagens de S. cerevisiae

Figura 6 - Determinação da estabilidade do DNA mitocondrial (mtDNA) .50

Figura 7 - Super-expressão das NADH desidrogenases mitocondriais .54

Figura 8 - Propriedades de crescimento das linhagens WT, $\Delta \operatorname{coq} 4$ e $\Delta \operatorname{coq} 10$ super-expressando as NADH desidrogenases a partir do promotor TEF1 (Figura A) e GAL10 (Figura B) .55

Figura 9 - Estabilidade do mtDNA nas linhagens com expressão aumentada de Nde1p, na presença e ausência da super-expressão de Coq8p .56

Figura 10 - Frequência da taxa de mutação no genoma mitocondrial através da formação de colônias resistentes a eritromicina $\left(\operatorname{Ery}^{\mathrm{R}}\right)$.

Figura 11 - Propriedades de crescimento das linhagens WT e $\triangle$ coq10 superexpressando as NADH desidrogenases a partir do promotor GAL10 com expressão aumentada da proteína Coq8p.

Figura 12 - Medidas da liberação de peróxido de hidrogênio (H2O2) em mitocôndrias isoladas a partir das linhagens com super-expressão da enzima Nde1p. 
Figura 13 - Medidas da liberação de peróxido de hidrogênio $\left(\mathrm{H}_{2} \mathrm{O}_{2}\right)$ em mitocôndrias isoladas a partir das linhagens com inativação da enzima Nde1p....... 


\section{SUMÁRIO}

1 INTRODUÇÃO

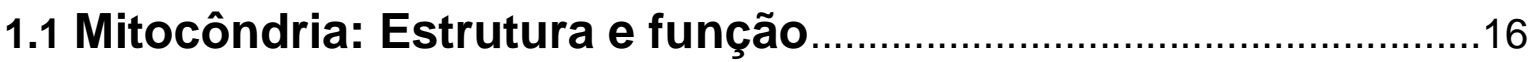

1.2 NADH desidrogenases mitocondriais..............................................19

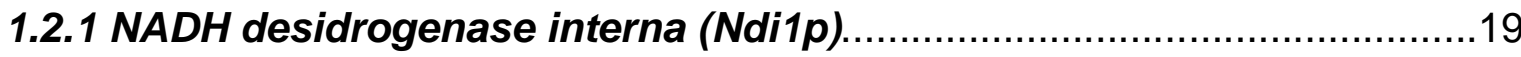

1.2.2 NADH desidrogenases externas (Nde1p e Nde2p)............................20

1.2.3 Lançadeira glicerol-3-fosfato desidrogenase ........................................21

1.3 A mitocôndria e a geração de espécies reativas de oxigênio21

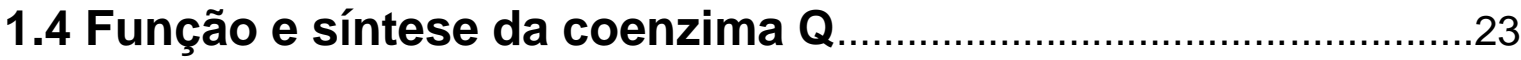

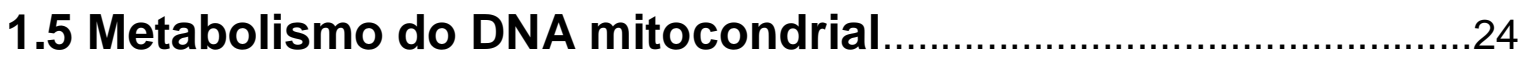

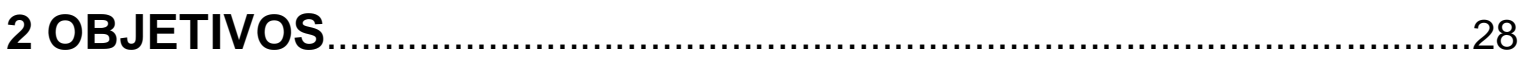

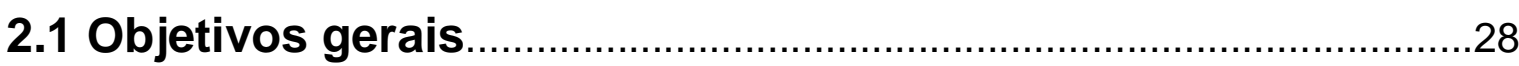

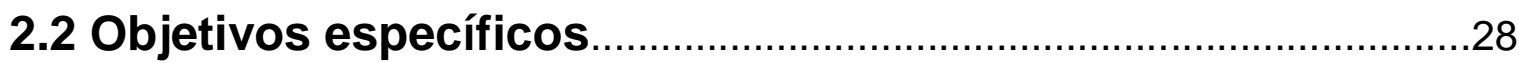

3 MATERIAIS E MÉTODOS

3.1 Linhagens de Saccharomyces cerevisiae e Escherichia

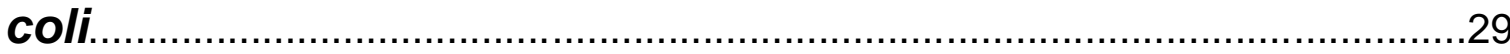

3.2 Meios de cultura dos microrganismos ........................................

3.3 Condições de cultivo dos microrganismos ……..........................31

3.4 Métodos gerais para manipulação do DNA ..................................31

3.5 Transformação das células de E. coli..........................................34

3.6 Transformação das células de S. cerevisiae.................................34

3.7 Extração do DNA genômico de S. cerevisiae...................................34

3.8 Determinação da estabilidade do mtDNA .....................................35

3.9 Ensaio de resistência a eritromicina ...............................................36

3.10 Isolamento de mitocôndrias de $S$. cerevisiae - método da

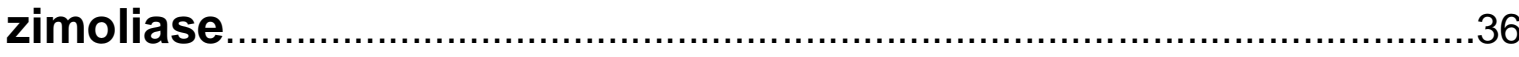

3.11 Análise das proteínas mitocondriais ........................................... 
3.12 Medidas do consumo de oxigênio

3.13 Medidas da liberação de peróxido de hidrogênio em mitocôndrias isoladas de S. cerevisiae.

3.14 Construção de mutantes nulos 39

4 RESULTADOS E DISCUSSÃO PARCIAL

4.1 Avaliação da instabilidade do mtDNA em diferentes mutantes respiratórios de S. cerevisiae.

4.2 Construção de mutantes nulos para as NADH desidrogenases mitocondriais.

4.3 Avaliação da liberação de peróxido de hidrogênio nas linhagens WT, $\Delta \operatorname{coq} 10$ e $\Delta \operatorname{coq} 4$ em combinação com a inativação das NADH desidrogenases mitocondriais

4.4 Avaliação da estabilidade do mtDNA nas linhagens WT, $\Delta \operatorname{coq} 10$ e $\Delta$ coq4 em combinação com a inativação das NADH desidrogenases mitocondriais

4.5 Super-expressão das NADH desidrogenases nas linhagens WT, $\Delta \operatorname{coq} 10$ e $\Delta \operatorname{coq} 4$.

5 DISCUSSÃO FINAL 63

6 CONCLUSÕES

7 REFERÊNCIAS 


\section{INTRODUÇÃO}

A mitocôndria é uma organela dinâmica que desempenha uma função central em diversos processos celulares. Uma de suas funções mais proeminentes é suprir a célula com energia metabólica na forma de ATP gerada pelo sistema de fosforilação oxidativa (SARRASTE, 1999). Participa também em muitas reações catabólicas e anabólicas, incluindo o ciclo do ácido cítrico, a $\beta$ oxidação de ácidos graxos e a biossíntese dos grupamentos heme e ferro-enxofre (LILL; MÜHLENHOFF, 2006; WINDE; GRIVELL, 1993). Em adição a sua função central em diversos processos bioquímicos a mitocôndria atua como um regulador chave da morte celular programada (TAIT; GREENN, 2010) e está intimamente relacionada com os processos de desenvolvimento e envelhecimento celular (LARSSON, 2010; WALLACE, 2005).

De acordo com a teoria endossimbionte, as mitocôndrias são derivadas de uma a-proteobactéria ancestral que foi engolfada por uma célula eucariótica primordial há aproximadamente 1,5-2 bilhões de anos atrás (DOLEZAL et al., 2006). Contendo genoma próprio e capacidade de sintetizar proteínas, as mitocôndrias são consideradas organelas semiautônomas. Embora a maioria das proteínas mitocondriais sejam traduzidas no citoplasma e pós traducionalmente importadas para o interior da organela, o genoma mitocondrial contem alguns genes que são essenciais para a montagem dos complexos respiratórios (WESTERMANN, 2010). Desta forma, a biogênese do sistema de fosforilação oxidativa requer a contribuição de dois genomas fisicamente separados: o nuclear (nDNA) e o mitocondrial (mtDNA). A regulação da atividade respiratória envolve ações coordenadas entre estes dois genomas, necessitando que o mtDNA seja corretamente replicado e transmitido entre as células filhas (CHEN; BUTOW, 2005; FALKENBERG et al., 2007; KELLY; SCARPULLA, 2004).

O entendimento do processo de manutenção do mtDNA tem despertado o interesse de muitos pesquisadores, uma vez que o envelhecimento humano está fortemente associado com o acúmulo de danos no mtDNA (KRISHNAN et al., 2007; LARSSON, 2010; TRIFUNOVIC et al., 2004). De fato, existe um grande número de informações demonstrando que o surgimento de mutações somáticas no mtDNA são importantes causadoras de doenças e estão envolvidas no 
envelhecimento humano (LARSSON, 2010; PARK; LARSSON, 2011; TAYLOR; TURNBULL, 2005; WALLACE, 2005; WALLACE, 2010).

A perda da funcionalidade do mtDNA também pode ser ocasionada por desordens gênicas nucleares, uma vez que todas as proteínas envolvidas na manutenção do mtDNA são de origem nuclear (TAYLOR; TURNBULL, 2005). Enquanto pouco se conhece sobre a função de genes nucleares envolvidos na manutenção do mtDNA nos eucariotos superiores, existem grandes quantidades de informações sobre seu funcionamento em Saccharomyces cerevisiae (CONTAMINE; PICARDI, 2000). Por ser um aeróbico facultativo, basta a levedura seu metabolismo fermentativo para sobreviver (OHLMEIER et al., 2004). Isto favoreceu o estabelecimento desse organismo como principal modelo de estudo da biogênese mitocondrial, principalmente através do isolamento de diversas coleções de mutantes respiratórios (McEWEN et al., 1986, TZAGOLOFF; DIECKMANN, 1990).

Devido a essas características, Saccharomyces cerevisiae tornou-se um excelente organismo modelo para a compreensão dos mecanismos moleculares que conduzem às doenças mitocondriais em humanos (BARRIENTOS, 2003). O entendimento dos mecanismos moleculares envolvidos na manutenção e transmissão do mtDNA na levedura poderá auxiliar no entendimento deste processo nos eucariotos superiores.

\subsection{Mitocôndria: estrutura e função}

A mitocôndria é uma organela composta de uma matriz solúvel rodeada por duas membranas: uma interna impermeável a íons e uma externa livremente permeável a íons e moléculas pequenas. O espaço existente entre as duas membranas, denominado espaço intermembranas, é o local onde é gerado o gradiente de prótons durante o processo de transferência de elétrons da cadeia respiratória.

$\mathrm{Na}$ matriz solúvel, também conhecida como matriz mitocondrial, encontram-se as enzimas responsáveis pelo catabolismo final das moléculas de 
alimento, incluindo as enzimas do ciclo do ácido cítrico, da $\beta$-oxidação de ácidos graxos e da oxidação de aminoácidos. A membrana interna apresenta uma extensa área de superfície em decorrência de suas inúmeras invaginações, conhecidas como cristas mitocondriais. Nelas está localizado o sistema de fosforilação oxidativa responsável pela geração de ATP a partir da energia liberada durante a transferência de elétrons da cadeia respiratória mitocondrial (SCHAFFER; SULEIMAN, 2007; TZAGOLOFF, 1982).

Funcionalmente, o sistema de fosforilação oxidativa é composto de cinco aglomerados protéicos conhecidos como complexos respiratórios I, II, III, IV e V. Em mamíferos, os complexos I, II, III e IV constituem a cadeia respiratória mitocondrial, enquanto o complexo $\mathrm{V}$ representa a ATP sintase. A fosforilação oxidativa inicia-se com a entrada de elétrons na cadeia respiratória a partir da oxidação das coenzimas hidrossolúveis $\mathrm{NADH}$ e $\mathrm{FADH}_{2}$ produzidas durante a oxidação das moléculas de alimento. O complexo I (NADH desidrogenase) promove a oxidação do NADH enquanto a oxidação do $\mathrm{FADH}_{2}$ é realizada pelo complexo II (succinato desidrogenase). Durante esta etapa os elétrons são transferidos sequencialmente para a ubiquinona, originando as formas parcialmente reduzida (ubisemiquinona) e a totalmente reduzida (ubiquinol). A ubiquinol então transfere seus elétrons para o complexo III (citocromo $c$ redutase), que em seguida os transfere para a proteína transportadora de elétrons citocromo c. A partir do citocromo $c$, os elétrons fluem para o complexo IV (citocromo $c$ oxidase) e, finalmente para o oxigênio, a etapa final da cadeia de transporte de elétrons (SARRASTE, 1999).

A energia liberada pelo fluxo dos elétrons através da cadeia respiratória é utilizada para bombear prótons $\left(\mathrm{H}^{+}\right)$da matriz mitocondrial para o espaço intermembranas, através dos complexos respiratórios I, III e IV. Este processo gera um gradiente eletroquímico através da membrana mitocondrial interna. A energia potencial armazenada no gradiente de prótons é posteriormente utilizada para promover a síntese de ATP através do complexo da ATP sintase (revisto em SCHULTZ; CHAN, 2001).

A mitocôndria de $S$. cerevisiae apresenta uma importante diferença em relação a maioria dos organismos eucarióticos. A cadeia respiratória deste 
microrganismo não contém o complexo respiratório I funcional constituído de múltiplas subunidades. Ao invés dele, a levedura possui três NADH desidrogenases localizadas na membrana mitocondrial interna que promovem 0 acoplamento da oxidação do NADH com a redução da ubiquinona (Figura 1), (BAKKER et al., 2001). Além disso, ao contrário de outros fungos, S. cerevisiae não apresenta uma oxidase alternativa (AOX), insensível ao cianeto, que catalisa a oxidação da ubiquinona diretamente pelo oxigênio molecular, sem gerar a força próton-motiva (VANLERBERGHE; MCINTOSH, 1997).

\section{Figura 1 - Representação esquemática da cadeia respiratória de Saccharomyces cerevisiae.}

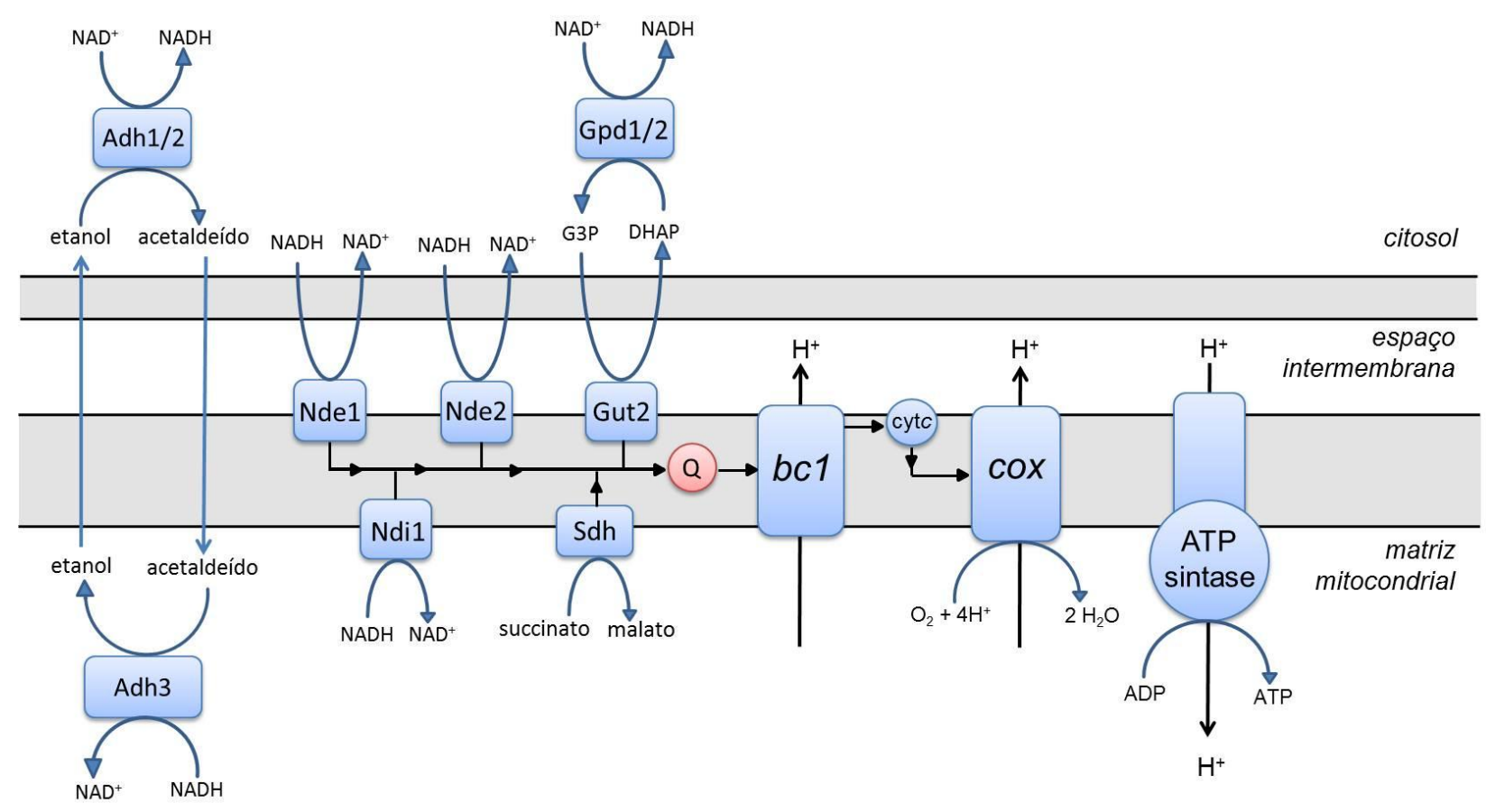

Adh, álcool desidrogenase; $b c 1$, complexo do citocromo bc1; cyt $c$, citocromo $c$; cox, citocromo $c$ oxidase; Gpd, glicerol-3-fosfato desidrogenase solúvel; Gut2, glicerol-3fosfato desidrogenase ligada a membrana; Nde1, NADH desidrogenase externa 1; Nde2, NADH desidrogenase externa 2; Ndi1, NADH desidrogenase interna; $Q$, ubiquinona; Sdh, complexo da succinato desidrogenase ligada ao $\mathrm{FADH}_{2}$; G3P, glicerol-3-fosfato; DHAP, diidroxiacetona fosfato.

Fonte: Adaptado de Bakker et al., (2001). 


\subsection{NADH desidrogenases mitocondriais}

\subsubsection{NADH desidrogenase interna (Ndi1p)}

Ao contrário das bactérias e da maioria das células eucarióticas, a mitocôndria de $S$. cerevisiae não possui o complexo I funcional constituído de múltiplas subunidades (GRANDIER-VAZEILLE et al., 2001; NOSEK; FUKUHARA, 1994;). Desta forma, a oxidação do NADH intramitocondrial ocorre por meio de uma NADH:ubiquinona oxidorredutase insensível a rotenona, conhecida como NADH desidrogenase interna 1 (Ndi1p). Esta enzima foi purificada e demonstrouse ser constituída de um único polipeptídeo com massa molecular de $57 \mathrm{KDa}$. A proteína possui uma molécula de FAD ligada covalentemente em sua estrutura como único grupo prostético (DeVRIES; GRIVEL, 1988; DeVRIES et al., 1992; MARRES et al., 1991). Localizada na membrana mitocondrial interna com o seu sítio ativo exposto para a matriz mitocondrial (MARRES et al., 1991), Ndi1p catalisa a transferência de dois elétrons do NADH intramitocondrial para a ubiquinona e, ao contrário do complexo I, é incapaz de bombear prótons para o espaço intermembranas durante esse processo (BAKKER et al., 2001; DeVRIES et al., 1987; MARRES et al., 1991; PERALES-CLEMENTE et al., 2008,).

Linhagens $\Delta$ ndi1 de $S$. cerevisiae apresentam crescimento semelhante ao das células selvagens quando cultivadas na presença de glicose, galactose ou etanol como única fonte de carbono (MARRES et al., 1991). O aparente crescimento da linhagem $\Delta$ ndi1 na presença de etanol sugere que o NADH intramitocondrial está sendo oxidado por mecanismos distintos de Ndi1p. Uma possível explicação para este fenótipo é o acoplamento da oxidação do NADH intramitocondrial com as NADH desidrogenases externas através da transferência de equivalentes redox da matriz mitocondrial para o citosol por meio da lançadeira etanol-acetaldeído (BAKKER et al., 2001).

A lançadeira etanol-acetaldeído, inicialmente proposta por Von Jagow e Klingenberg (1970), é constituída pelas isoenzimas da álcool desidrogenase mitocondrial Adh3p e citosólicas Adh1p e Adh2p. Ambas promovem a redução do acetaldeído a etanol através do NADH. Uma vez que o etanol e o acetaldeído se difundem livremente através de membranas biológicas, nenhum transportador é 
necessário para promover a troca entre $\mathrm{NADH}$ mitocondrial e $\mathrm{NAD}^{+}$citosólico (BAKKER et al., 2001).

Nos últimos anos tem-se proposto que o gene NDI1 de levedura pode ser utilizado na terapia gênica para o tratamento de pacientes com deficiência do complexo respiratório I. Esta proposta é baseada em trabalhos que mostraram que a expressão heteróloga do gene NDI1 de S. cerevisiae foi capaz de recuperar a atividade respiratória das células de mamíferos apresentando defeitos no complexo I (BAl et al., 2001; PERALES-CLEMENTE et al., 2008; SEO et al., 1998; SEO et al., 1999). A atividade respiratória apresentada pelas células não foi inibida pela rotenona, um inibidor conhecido do complexo I de mamíferos, significando que a oxidação do NADH foi de fato promovida pela enzima Ndi1p (SEO et al., 1998). Juntos, estes estudos apontam que a expressão funcional do gene NDI1 de levedura pode atuar como uma possível estratégia terapêutica para o tratamento de doenças mitocondriais humanas nas quais haja deficiência na montagem do complexo I, que constituem os casos de maior frequência dentre as patogenias mitocondriais (TUCKER, et al., 2011; YAGl et al., 2006).

\subsubsection{NADH desidrogenases externas (Nde1p e Nde2p)}

A mitocôndria de $S$. cerevisiae acopla a oxidação do NADH citosólico à cadeia respiratória mitocondrial através de duas atividades enzimáticas conhecidas como NADH desidrogenase externa 1 (Nde1p) e 2 (Nde2p) (LUTTICK et al., 1998; SMALL; McALISTER-HENN, 1998). Identificadas com base em sua homologia com Ndi1p, ambas situam-se na membrana mitocondrial interna com os seus sítios catalíticos orientados em direção ao espaço intermembrana (LUTTIK et al., 1998). Semelhante a NADH desidrogenase interna, as isoenzimas externas são insensíveis a rotenona e não bombeiam prótons para o espaço intermembrana durante a transferência de elétrons (BAKKER et al., 2001).

A taxa de crescimento do duplo mutante $\Delta$ nde1 $\Delta$ nde2 na presença de galactose ou etanol como fonte de carbono é ligeiramente menor em relação a linhagem parental de referência (LUTTICK et al., 1998; SMALL; McALISTERHENN, 1998). Isto indica que mecanismos alternativos capazes de acoplar a oxidação do $\mathrm{NADH}$ citosólico com a cadeia respiratória mitocondrial (ex: a 
lançadeira de glicerol 3-fosfato) não substituem completamente a atividade das $\mathrm{NADH}$ deidrogenases externas (BAKKER et al., 2001). A diminuição na taxa de crescimento do duplo mutante é principalmente devido a ausência de Nde1p, uma vez que a interrupção de Nde2p não causou nenhum efeito sobre a taxa de oxidação do NADH citosólico (LUTTICK et al., 1998). Isto sugere que durante o crescimento respiratório, Nde1p é fisiologicamente mais importante do que Nde2p (BAKKER et al., 2001).

A importância de Nde1p para a oxidação do NADH citosólico foi demonstrada através do modelo de competição de elétrons durante a entrada na cadeia respiratória proposto por Bunoust e colaboradores (2005). De acordo com este modelo, a enzima Nde1p possui uma preferência pelo lançamento de elétrons para o interior da cadeia respiratória em relação às enzimas Ndi1p e Gut2p. Através de medições da taxa respiratória na presença de diferentes substratos respiratórios, os autores demonstraram que as atividades de Ndi1p e Gut2p são fortemente inibidas pela enzima Nde1p (BUNOUST et al., 2005). Essa inibição ocorreria pela competição entre as desidrogenases pelo fornecimento de elétrons para o interior da cadeia respiratória (BUNOUST, et al., 2005; RIGOULET, et al., 2010).

\subsubsection{Lançadeira glicerol-3-fosfato desidrogenase}

Além das NADH desidrogenases externas, a cadeia respiratória de $S$. cerevisiae apresenta um terceiro componente responsável pela acoplagem da oxidação do NADH citosólico com a redução da coenzima Q. Este sistema, conhecido como lançadeira glicerol-3-fosfato desidrogenase, é constituído por dois componentes: duas isoenzimas da glicerol-3-fosfato desidrogenase citosólica (Gpd1/2p) e a glicerol-3-fosfato desidrogenase mitocondrial (Gut2p). Durante a atividade dessa lançadeira, o NADH citosólico é utilizado para promover a redução da diidroxiacetona fosfato à glicerol-3-fosfato, em uma reação catalisada pela enzima Gpd1/2p. Posteriormente, o glicerol-3-fosfato entrega seus elétrons diretamente para a cadeia respiratória mitocondrial, através da enzima Gut2, regenerando dessa forma a diidroxiacetona fosfato (LARSSON et al., 1998). 


\subsection{A mitocôndria e a geração de espécies reativas de oxigênio}

Embora existam vários potenciais sítios geradores de espécies reativas de oxigênio (EROs) no interior da célula, a mitocôndria é considerada a principal fonte geradora destas espécies em decorrência do seu elevado metabolismo oxidativo (revisto em KOWALTOWSKI, et al., 2009). As principais EROs incluem, os íons superóxido $\left(\mathrm{O}_{2}{ }^{-}\right)$, os radicais hidroxila $(\mathrm{OH})$, o peróxido de hidrogênio $\left(\mathrm{H}_{2} \mathrm{O}_{2}\right)$ e o oxigênio "singlete" (KOWALTOWSKI, et al., 2009).

As EROs são geradas pela redução incompleta do oxigênio molecular durante o processo de fosforilação oxidativa. Em centros redox específicos da cadeia respiratória mitocondrial, elétrons derivados do $\mathrm{NADH}$ e do $\mathrm{FADH}_{2}$ podem reagir diretamente com o oxigênio molecular resultando na geração do ânion superóxido, o principal precursor das EROs (MURPHY, 2009). Estudos apontam, que os principais centros de geração de EROs da cadeia respiratória são os complexos respiratórios I e III (BALABAN et al., 2005; HERRERO et al., 2008; SUN; TRUMPOWER, 2003; TURRENS, 2003). As NADH desidrogenases externas (Nde1p e Nde2p) de $S$. cerevisiae também estão envolvidas na geração de superóxido (FANG; BEATTIE, 2003).

O acúmulo de EROs conduz ao estresse oxidativo, uma condição no qual os constituintes celulares, incluindo lipídeos, proteínas e DNA, são extensivamente oxidados e danificados (VEAL et al., 2007; WELLEN; THOMPSON, 2010). Particularmente, tem-se assumido que o mtDNA apresenta elevada susceptibilidade aos danos oxidativos, principalmente devido sua proximidade em relação a cadeia de transporte de elétrons. Os danos oxidativos provocados no mtDNA podem danificar genes do sistema de fosforilação oxidativa, ocasionando o bloqueio da cadeia respiratória e consequentemente um aumento na produção de EROs. Como resultado, ocorre uma alça de alimentação positiva entre produção de EROs e danos oxidativos provocados no mtDNA (TRACHOOTHAM et al., 2009)

Para diminuir os efeitos nocivos das EROs e impedir o estresse oxidativo, as células utilizam vários sistemas de defesa antioxidantes (BENTINGER et al., 2007; HERRERO et al., 2008). Estes incluem a glutationa, a tiorredoxina, a superóxido dismutase (SOD), a catalase e as peroxidases. As enzimas 
superóxidos dismutases promovem a dismutação do radical super-óxido a peróxido de hidrogênio, enquanto as enzimas glutationa peroxidase, tiorredoxina peroxidase e catalase, catalisam a redução do peróxido de hidrogênio a água.

O estresse oxidativo causado pelos efeitos das EROs nas células tem sido associado com a patogênese de muitas doenças, particularmente as neurodegenerativas. O acúmulo de danos oxidativos causados pelas EROs ao longo da vida de um organismo é a base da "teoria dos radicais livres" do envelhecimento (HARMAN, 1956). De acordo com essa teoria, o envelhecimento, bem como as doenças degenerativas a ele associadas, podem ser atribuídos aos efeitos deletérios dos radicais livres sobre vários componentes celulares. Em particular, danos provocados ao DNA mitocondrial (mtDNA) tem sido apontado como um dos principais responsáveis pelo processo de envelhecimento, devido a perda da atividade mitocondrial (WALLACE et al., 2010).

\subsection{Função e síntese da coenzima $Q$}

A coenzima $Q$, também conhecida como ubiquinona ou simplesmente $Q$, é um carregador de elétrons lipofílico essencial da cadeia respiratória mitocondrial cuja principal função é transferir elétrons dos complexos respiratórios I e II para o complexo do citocromo bc1 (HATEFI, 1985; LENAZ et al., 2007). Durante sua ação na cadeia respiratória mitocondrial, CoQ existe em três estados redox: completamente oxidada (ubiquinona), o radical semiquinona (ubisemiquinona) e completamente reduzida (ubiquinol) (LENAZ et al., 2007; LENAZ; GENOVA, 2009).

Além de sua função na transferência de elétrons, a coenzima $Q$ desempenha outras funções importantes dentro da célula. Nos últimos anos, diversos trabalhos demonstraram que a coenzima $Q$ atua como importante antioxidante impedindo a oxidação de lipídeos, proteínas e DNA (BENTINGER et al., 2007). Além disso, participa no controle da abertura dos poros de transição da membrana mitocondrial e regula a atividade das proteínas desacopladoras (BENTINGER et al., 2010).

A molécula de coenzima $Q$ é constituída por um anel de benzoquinona ligado a uma cadeia de poliprenil, com 6 unidades de repetição em $S$. cerevisiae (CoQ6) e 10 em humanos (CoQ10) (KAWAMUKAI, 2009; MARBOIS et al., 2005; 
PIERREL et al., 2010). Em S. cerevisiae, a biossíntese da coenzima $Q$ é realizada por uma série de enzimas da matriz mitocondrial, algumas das quais estão associadas em um grande complexo biossintético ancorado na membrana mitocondrial interna (revisto em TRAN; CLARK, 2007). Até o momento já foram descritos 11 genes de levedura envolvidos na síntese da CoQ6. Seus produtos gênicos catalisam modificações do tipo metilações e hidroxilações do anel benzoquinona, bem como a maturação e a inserção da cauda poliprenil (PIERREL et al., 2010; TRAN; CLARK, 2007;).

Linhagens de levedura mutantes para os genes coq (COQ1-COQ9) apresentam deficiência respiratória, sendo incapazes de crescer na presença de uma fonte de carbono não fermentável. Em 2005, Barros e colaboradores, identificaram um novo mutante coq de levedura que apresenta defeitos na oxidação do NADH e do succinato (BARROS et al., 2005). No entanto, ao contrário dos outros mutantes coq (COQ1-COQ9) deficientes de coenzima Q, o mutante coq10 possui níveis normais desta molécula, indicando que a proteína Coq10p não está envolvida na sua biossíntese (BARROS et al., 2005).

Coq10p é uma proteína de $24 \mathrm{KDa}$ e assim como os demais produtos dos genes coq, está localizada na membrana mitocondrial interna (revisto em TRAN; CLARK, 2007). Apesar de sua função não estar completamente elucidada, existem fortes evidências demonstrando que a proteína Coq10p poderia atuar no transporte, ou no direcionamento da CoQ6 para a sua correta localização na cadeia respiratória (BARROS et al., 2005; BUSSO et al., 2010a; CUl; KAWAMUKAI, 2009). Isto foi apoiado pelo fato de Coq10p se ligar a coenzima $Q$ possivelmente através de um túnel de ligação presente em sua estrutura (BARROS et al., 2005; BUSSO et al., 2010a; CUI; KAWAMUKAI, 2009;).

\subsection{Metabolismo do DNA mitocondrial}

O mtDNA contem um pequeno, porém essencial, subconjunto de genes necessários para o sistema de fosforilação oxidativa mitocondrial. Em $S$. cerevisiae, por exemplo, o genoma mitocondrial contem os genes para as subunidades 1,2 e 3 da citocromo $c$ oxidase, do apocitocromo $b$, das 
subunidades 6, 8 e 9 da ATP sintase e de uma proteína ribossomal (VAR1) (FOURY et al.,1998).

No interior da mitocôndria o mtDNA encontra-se organizado em complexos de proteínas-DNA denominados nucleóides. A forma e o tamanho dos nucleóides variam entre as diferentes espécies. Em S. cerevisiae, o genoma mitocondrial de 75-KB encontra-se empacotado no interior de uma estrutura nucleóide globular com um diâmetro médio de 0,3 $\mu \mathrm{m}$ nas células aeróbicas. Dentro dessa estrutura globular pode existir de 1 a 2 genomas mitocondriais (CHEN; BUTOW, 2005).

Atualmente já foram descritas aproximadamente 30 proteínas como potenciais componentes dos nucleóides mitocondriais. Dentre elas, estão proteínas que atuam diretamente no metabolismo do DNA mitocondrial, como por exemplo Abf2p, a principal responsável pelo empacotamento do mtDNA (CHEN; BUTOW, 2005). Curiosamente, proteínas que atuam principalmente no metabolismo intermediário das moléculas de alimentos sob determinadas condições metabólicas tornam-se componentes essenciais na organização dos nucleóides (KUCEJ, et al., 2008). Dentre essas proteínas, destacam-se Aco1p, uma enzima do ciclo de Krebs, e Ilv5p, enzima envolvida na síntese de aminoácidos de cadeia ramificada (CHEN; BUTOW, 2005).

A levedura $S$. cerevisiae é um excelente organismo modelo para o estudo das bases moleculares dos processos envolvidos na manutenção do mtDNA. Ao contrário dos metazoários, S. cerevisiae é um anaeróbio facultativo podendo sobreviver sem o mtDNA utilizando apenas o metabolismo fermentativo para 0 seu crescimento (LIPINSK et al., 2010). Células de leveduras com o genoma mitocondrial defeituoso, seja pela perda parcial do mtDNA (mutantes rho') ou devido a ausência total do mtDNA (mutantes $r h 0^{\circ}$ ), são denominadas como "petites" devido elas formarem pequenas colônias quando cultivadas em uma fonte de carbono fermentável (EPHRUSSI, 1949). Ao contrário, células que possuem o genoma mitocondrial funcional originam colônias do tipo "grande" e são denominadas $\left(r h o^{+}\right)$. Ambos os mutantes $r h o^{0}$ e $r h o^{-}$podem ser facilmente cultivados sobre uma fonte de carbono fermentável tal como a glicose.

A instabilidade do genoma mitocondrial pode ser quantitativamente mensurada através da frequência de aparecimento de colônias petites em uma 
população de células de levedura. Isto facilita o estudo de genes envolvidos na manutenção do mtDNA, uma vez ausentes, estes genes alteram a frequência de formação de colônias petites (DIMITROV, et al., 2009)

Mais de 200 genes são necessários para a correta manutenção do genoma mitocondrial em S. cerevisiae (CONTAMINE; PICARD, 2000; HESS et al., 2009). Entretanto, somente uma pequena fração destes genes estão envolvidos em mecanismos que diretamente afetam o metabolismo do mtDNA tais como replicação, recombinação e reparo, bem como o empacotamento do mtDNA nos nucleóides (CHEN; BUTOW, 2005; CONTAMINE; PICARD, 2000; DIMITROV, et al., 2009; LIPINSK et al., 2010). Genes envolvidos em outros processos mitocondriais representam a vasta maioria dos genes que influenciam a integridade do genoma mitocondrial (revisto em CONTAMINE; PICARD, 2000). Notavelmente, a correta expressão do genoma mitocondrial é crucial para a sua manutenção e, a inativação de genes codificando proteínas envolvidas na transcrição e tradução mitocondrial levam a sua instabilidade (FANGMAN; HENLY, 1990; GREENLEAF et al., 1986; MYERS et al., 1985).

Efeitos sobre a estabilidade do genoma mitocondrial também são observados como resultado da inativação de genes envolvidos no combate do estresse oxidativo (CONTAMINE; PICARD, 2000). Dentre esses genes, estão aqueles que atuam na eliminação das EROs bem como no sequestro de íons metálicos (DOUDICAN et al., 2005). A inativação do gene YFH1 em S. cerevisiae, exemplifica muito bem os efeitos do estresse oxidativo sobre a estabilidade do mtDNA. A ausência da proteína Yfh1p resulta no acúmulo de grandes quantidades de ferro no interior da mitocôndria (BABCOCK et al., 1997; FOURY; CAZZALINI, 1997). O ferro por sua vez, é um catalisador da reação de Fenton, um dos principais responsáveis pela geração dos radicais hidroxila (HERRERO et al., 2008). Estes são extremamente reativos e provocam danos extensivos em moléculas biológicas tais como o mtDNA. De fato, a deleção de YFH1 em $S$. cerevisiae causa elevada instabilidade do genoma mitocondrial (FOURY; CAZZALINI, 1997; WILSON; ROOF, 1997). O homólogo de YFH1 em humanos, denominado FDRA, codifica uma proteína conhecida como frataxina (CAMPUZANO et al., 1996). Defeitos na produção dessa proteína tem sido associados à doença ataxia de Friedreich's, uma doença degenerativa 
autossômica recessiva que afeta principalmente o sistema nervoso e o coração. A administração de análogos de coenzima $Q$ a esses pacientes tem se mostrado benéfico, provavelmente pelo seu efeito antioxidante (RUSTIN et al., 1999).

Em 2005, Barros e colaboradores reportaram que a deleção do gene $C O Q 10$, envolvido no metabolismo da coenzima $Q$, causa elevada instabilidade do mtDNA. Linhagens de $S$. cerevisiae W $303 \Delta$ coq10 crescendo em meio rico contendo glicose consistem em cerca de $\sim 50 \%$ de células petites. A elevada instabilidade do mtDNA observada nesse mutante pode ser decorrente da produção excessiva de EROs, visto que nesse mutante, a transferência de elétrons depende de coenzima $Q$ é parcialmente interrompida (BUSSO et al., 2010b).

Esse trabalho iniciou-se justamente com a perspectiva de compreender os motivos que levam o mutante $\Delta \operatorname{coq} 10$ a apresentar essa elevada instabilidade na manutenção do seu mtDNA. O entendimento desse fenótipo se torna estritamente necessário principalmente após a publicação de trabalhos associando as desordens mitocondriais humanas com defeitos no metabolismo da coenzima $Q$ (Lagier-Tourenne et al., 2008; Quinzii e Hirano, 2010; Heeringa et al., 2011). 


\section{OBJETIVOS}

\subsection{Objetivo geral}

- Avaliar o envolvimento da coenzima Q na estabilidade do mtDNA em $S$. cerevisiae.

\subsection{Objetivos específicos}

- Compreender os motivos que levam o mutante $\Delta$ coq10 a apresentar elevada instabilidade do mtDNA

- Promover alterações no estado redox da coenzima $Q$ através da interrupção do fornecimento de elétrons para a cadeia respiratória mitocondrial

- Avaliar os efeitos das alterações no estado redox da coenzima $Q$ sobre a estabilidade do mtDNA 


\section{MATERIAIS E MÉTODOS}

\subsection{Linhagens de Saccharomyces cerevisiae e Escherichia coli}

As linhagens de $S$. cerevisiae e $E$. coli utilizadas neste trabalho estão listadas na tabela 3.1 .

Tabela 3.1- Linhagens de E. coli e S. cerevisiae.

continua

\begin{tabular}{|c|c|c|}
\hline \multicolumn{3}{|c|}{ Escherichia coli } \\
\hline Linhagem & Genótipo & Referência \\
\hline $\mathrm{RR} 1$ & $\begin{array}{l}\text { ( }(\text { gpt-proA)62, leuB6, thi-1, lacY1, hsdSB20, } \\
\text { rpsL20 (Strr), ara-14, galK2, xyl-5, mtl-1, supE44, } \\
\text { mcrBB) }\end{array}$ & (Hanahan, 1983). \\
\hline \multicolumn{3}{|c|}{ Saccharomyces cerevisiae } \\
\hline Linhagem & Genótipo & Referência \\
\hline W303-1A & $\begin{array}{l}\text { MATa ade2-1 trp1-1 his3-1,15 leu2-3,112 ura3-1 } \\
\rho+\text { can }^{R}\end{array}$ & $\begin{array}{l}\text { Rothstein, } R . \\
\text { Columbia (University) }\end{array}$ \\
\hline W303-1B & $\begin{array}{l}\text { MATa ade2-1 trp-1 his3-1,15 leu2- } \\
\text { 3,112 ura3-1 } \rho+\text { can }^{R}\end{array}$ & $\begin{array}{l}\text { Rothstein, } \quad \mathrm{R} . \\
\text { Columbia (University) }\end{array}$ \\
\hline CB11 & MATa ade $1 \rho^{\circ}$ & Tzagoloff et al., 1975 \\
\hline KL14 & MATa his1 trp2 $\rho^{\circ}$ & Tzagoloff et al., 1975 \\
\hline W303 $\triangle C O Q 2$ & $\begin{array}{l}\text { MATa ade2-1 his3-1,15 leu2-3,112 trp1-1 ura3-1 } \\
\text { coq2::HIS3 }\end{array}$ & Ashby et al., 1992 \\
\hline W303 $\triangle C O Q 4$ & $\begin{array}{l}\text { MATa ade2-1 his3-1,15 leu2-3,112 trp1-1 ura3-1 } \\
\text { coq4::TRP1 }\end{array}$ & Hsu et al., 2000 \\
\hline W303 $\triangle C O Q 10$ & $\begin{array}{l}\text { MATa ade2-1 his3-1,15 leu2-3,112 trp1-1 ura3-1 } \\
\text { coq10::HIS3 }\end{array}$ & Barros et al., 2005 \\
\hline W303 $\triangle \mathrm{COX} 11$ & $\begin{array}{l}\text { MATa ade2-1 his3-1,15 leu2-3,112 trp1-1 ura3-1 } \\
\text { cox11::HIS3 }\end{array}$ & Tzagoloff et al., 1990 \\
\hline W303 $\triangle C O X 15$ & $\begin{array}{l}\text { MATa ade2-1 his3-1,15 leu2-3,112 trp1-1 ura3-1 } \\
\text { cox15::HIS3 }\end{array}$ & Glerum et al., 1995. \\
\hline W303 $\triangle C O X 17$ & $\begin{array}{l}\text { MATa ade2-1 his3-1,15 leu2-3,112 trp1-1 ura3-1 } \\
\text { cox17::HIS3 }\end{array}$ & Glerum et al., 1995. \\
\hline W303 $\triangle B C S 1$ & $\begin{array}{l}\text { MATa ade2-1 his3-1,15 leu2-3,112 trp1-1 ura3-1 } \\
\text { bcs1::HIS3 }\end{array}$ & Nobrega et al., 1992. \\
\hline W303 $\triangle C O R 1$ & $\begin{array}{l}\text { MATa ade2-1 his3-1,15 leu2-3,112 trp1-1 ura3-1 } \\
\text { cor1::HIS3 }\end{array}$ & Tzagoloff et al., 1996. \\
\hline W303ARIP1 & $\begin{array}{l}\text { MATa ade2-1 his3-1,15 leu2-3,112 trp1-1 ura3-1 } \\
\text { rip1::HIS3 }\end{array}$ & $\begin{array}{l}\text { Alexander Tzagoloff } \\
\text { (Columbia University) }\end{array}$ \\
\hline W303ANDI1 & $\begin{array}{l}\text { MATa ade2-1 his3-1,15 leu2-3,112 trp1-1 ura3-1 } \\
\text { ndi1::URA3 }\end{array}$ & Este estudo \\
\hline
\end{tabular}




\begin{tabular}{|c|c|c|}
\hline W303 $\triangle N D E 1$ & $\begin{array}{l}\text { MATa ade2-1 his3-1,15 leu2-3,112 trp1-1 } \\
\text { ura3-1 nde1::HIS3 }\end{array}$ & $\frac{\text { continuaçãc }}{\text { Este estudo }}$ \\
\hline W303 $\triangle N D E 2$ & $\begin{array}{l}\text { MATa ade2-1 his3-1,15 leu2-3,112 trp1-1 } \\
\text { ura3-1 nde2::LEU2 }\end{array}$ & Este estudo \\
\hline W303 $\triangle N D E 1 \triangle N D E 2$ & $\begin{array}{l}\text { MATa ade2-1 } \text { his3-1,15 leu2-3,112 } \\
\text { trp1-1 ura3-1 nde1::HIS3 nde2::LEU2 }\end{array}$ & Este estudo \\
\hline W303 $\triangle N D I 1 \triangle N D E 1$ & $\begin{array}{l}\text { MATa ade2-1 his3-1,15 leu2-3,112 } \\
\text { trp1-1 ura3-1 ndi1::URA3 nde1::HIS3 }\end{array}$ & Este estudo \\
\hline $\begin{array}{l}\text { W303 } \triangle N D / 1 \Delta N D E 1 \\
\triangle N D E 2\end{array}$ & $\begin{array}{lrrr}\text { MATa ade2-1 } & \text { his3-1,15 } & \text { leu2-3,112 } \\
\text { trp1-1 ura3-1 } & \text { ndi1::URA3 } & \text { nde1::HIS3 } \\
\text { nde2::LEU2 } & & \end{array}$ & Este estudo \\
\hline W303 $\triangle C O Q 4 \triangle N D I 1$ & $\begin{array}{l}\text { MATa ade2-1 his3-1,15 leu2-3,112 trp1-1 } \\
\text { ura3-1 coq4::TRP1 ndi1::URA3 }\end{array}$ & Este estudo \\
\hline W303 $\triangle C O Q 4 \triangle N D E 1$ & $\begin{array}{l}\text { MATa ade2-1 his3-1,15 leu2-3,112 trp1-1 } \\
\text { ura3-1 coq4::TRP1 nde1::HIS3 }\end{array}$ & Este estudo \\
\hline W303 $\triangle C O Q 4 \triangle N D E 2$ & $\begin{array}{l}\text { MATa ade2-1 his3-1,15 leu2-3,112 trp1-1 } \\
\text { ura3-1 coq4::TRP1 nde2::LEU2 }\end{array}$ & Este estudo \\
\hline $\begin{array}{l}\text { W303 } \triangle C O Q 4 \triangle N D E 1 \\
\triangle N D E 2\end{array}$ & $\begin{array}{lcrr}\text { MATa ade2-1 } & \text { his3-1,15 } & \text { leu2-3,112 } \\
\text { trp1-1 ura3-1 } & \text { coq4::TRP1 } & \text { nde1::HIS3 } \\
\text { nde2::LEU2 } & & \\
\end{array}$ & Este estudo \\
\hline $\begin{array}{l}\text { W303 } \triangle C O Q 4 \Delta N D / 1 \\
\triangle N D E 1\end{array}$ & $\begin{array}{lcrr}\text { MATa } & \text { ade2-1 } & \text { his3-1,15 } & \text { leu2-3,112 } \\
\text { trp1-1 ura3-1 } & \text { coq4::TRP1 } & \text { ndi1::URA3 } \\
\text { nde1::HIS3 } & & \\
\end{array}$ & Este estudo \\
\hline $\begin{array}{l}\text { W303 } \triangle C O Q 4 \triangle N D I 1 \\
\triangle N D E 1 \triangle N D E 2\end{array}$ & $\begin{array}{lcrr}\text { MATa } & \text { ade2-1 } & \text { his3-1,15 } & \text { leu2-3,112 } \\
\text { trp1-1 } & \text { ura3-1 } & \text { coq4:::TRP1 } & \text { ndi1::URA3 } \\
\text { nde1::HIS3 nde2::LEU2 } & \end{array}$ & Este estudo \\
\hline W303 $\triangle C O Q 10 \Delta N D I 1$ & $\begin{array}{l}\text { MATa ade2-1 his3-1,15 leu2-3,112 trp1-1 } \\
\text { ura3-1 coq10::HIS3 ndi1::URA3 }\end{array}$ & Este estudo \\
\hline W303 $\triangle C O Q 10 \triangle N D E 1$ & $\begin{array}{l}\text { MATa ade2-1 his3-1,15 leu2-3,112 trp1-1 } \\
\text { ura3-1 coq10::HIS3 nde1::HIS3 }\end{array}$ & Este estudo \\
\hline W303 $\triangle C O Q 10 \triangle N D E 2$ & $\begin{array}{l}\text { MATa ade2-1 his3-1,15 leu2-3,112 trp1-1 } \\
\text { ura3-1 coq10::HIS3 nde2::LEU2 }\end{array}$ & Este estudo \\
\hline $\begin{array}{l}\text { W303 } \triangle C O Q 10 \triangle N D E 1 \\
\triangle N D E 2\end{array}$ & $\begin{array}{lrrr}\text { MATa } & \text { ade2-1 } & \text { his3-1,15 } & \text { leu2-3,112 } \\
\text { trp1-1 ura3-1 } & \text { coq10::HIS3 } & \text { nde1::HIS3 } \\
\text { nde2::LEU2 } & & \\
\end{array}$ & Este estudo \\
\hline $\begin{array}{l}\text { W303 } \triangle C O Q 10 \Delta N D / 1 \\
\triangle N D E 1\end{array}$ & $\begin{array}{lrrr}\text { MATa } & \text { ade2-1 } & \text { his3-1,15 } & \text { leu2-3,112 } \\
\text { trp1-1 ura3-1 } & \text { coq10::HIS3 } & \text { ndi1::URA3 } \\
\text { nde1::HIS3 } & & \\
\end{array}$ & Este estudo \\
\hline $\begin{array}{l}\text { W303 } \triangle C O Q 10 \Delta N D / 1 \\
\triangle N D E 1 \triangle N D E 2\end{array}$ & $\begin{array}{lcrr}\text { MATa } & \text { ade2-1 } & \text { his3-1,15 } & \text { leu2-3,112 } \\
\text { trp1-1 ura3-1 } & \text { coq10::HIS3 } & \text { ndi1::URA3 } \\
\text { nde1::HIS3 nde2::LEU2 } & \end{array}$ & Este estudo \\
\hline W303/GAL10NDE1 & 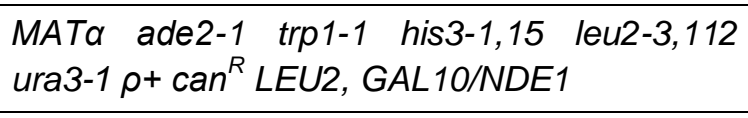 & Este estudo \\
\hline W303/GAL10NDE2 & 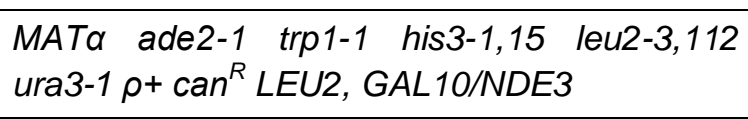 & Este estudo \\
\hline W303/GAL10NDI1 & $\begin{array}{l}\text { MATd ade2-1 trp1-1 his3-1,15 leu2-3,112 } \\
{\text { ura3-1 } \rho+\operatorname{can}^{R} \text { LEU2, GAL10/NDI1 }}\end{array}$ & Este estudo \\
\hline
\end{tabular}


conclusão

\begin{tabular}{|c|c|c|}
\hline $\begin{array}{l}\text { W303 } \triangle C O Q 4 / G A L 10 \\
\text { NDE1 }\end{array}$ & $\begin{array}{l}\text { MATa ade2-1 his3-1,15 leu2-3,112 trp1-1 ura3-1 } \\
\text { coq4::TRP1 LEU2, GAL10/NDE1 }\end{array}$ & Este Estudo \\
\hline $\begin{array}{l}\text { W303 } \triangle C O Q 4 / G A L 10 \\
\text { NDE2 }\end{array}$ & $\begin{array}{l}\text { MATa ade2-1 his3-1,15 leu2-3,112 trp1-1 ura3-1 } \\
\text { coq4::TRP1 LEU2, GAL10/NDE2 }\end{array}$ & Este estudo \\
\hline $\begin{array}{l}\text { W303 } \triangle C O Q 4 / G A L 10 \\
\text { NDI1 }\end{array}$ & $\begin{array}{l}\text { MATa ade2-1 his3-1,15 leu2-3,112 trp1-1 ura3-1 } \\
\text { coq4::TRP1 LEU2, GAL10/NDI1 }\end{array}$ & Este Estudo \\
\hline $\begin{array}{l}\text { W303 } \triangle C O Q 10 / G A L 10 \\
\text { NDE1 }\end{array}$ & $\begin{array}{l}\text { MATa ade2-1 his3-1,15 leu2-3,112 trp1-1 ura3-1 } \\
\text { coq10::HIS3 LEU2, GAL10/NDE1 }\end{array}$ & Este estudo \\
\hline $\begin{array}{l}\text { W303 } \triangle C O Q 10 / G A L 10 \\
\text { NDE2 }\end{array}$ & $\begin{array}{l}\text { MATa ade2-1 his3-1,15 leu2-3,112 trp1-1 ura3-1 } \\
\text { coq10::HIS3 LEU2, GAL10/NDE2 }\end{array}$ & Este estudo \\
\hline $\begin{array}{l}\text { W303 } \triangle C O Q 10 / G A L 10 \\
\text { NDI1 }\end{array}$ & $\begin{array}{l}\text { MATa ade2-1 his3-1,15 leu2-3,112 trp1-1 ura3-1 } \\
\text { coq10::HIS3 LEU2, GAL10/NDI1 }\end{array}$ & Este estudo \\
\hline $\begin{array}{l}\text { W303/GAL10NDE1/ } \\
\text { GPDCOQ8 }\end{array}$ & $\begin{array}{l}\text { MATa ade2-1 trp1-1 his3-1,15 leu2-3,112 ura3-1 } \\
\rho^{+} \quad \text { can }^{R} \text { LEU2, GAL10/NDE1 URA3, } \\
\text { GPD/COQ8 }\end{array}$ & Este estudo \\
\hline $\begin{array}{l}\text { W303 } \triangle \text { coq10/GAL10 } \\
\text { NDE1/GPDCOQ8 }\end{array}$ & $\begin{array}{l}\text { MATa ade2-1 trp1-1 his3-1,15 leu2-3,112 ura3-1 } \\
\rho+\text { can }^{R} \text { coq10::HIS3 LEU2, GAL10/NDE1 } \\
\text { URA3, GPD/COQ8 }\end{array}$ & Este estudo \\
\hline
\end{tabular}

\subsection{Meios de cultura dos microrganismos}

As composições dos meios de cultura para o crescimento dos microrganismos utilizados neste trabalho estão listados na tabela 3.2. Todos os meios de cultivo foram preparados e autoclavados por 15 minutos a $120 \stackrel{\circ}{\mathrm{C}}$ para esterilização como descrito por Sambrook et al., (1989). Os meios sólidos foram preparados conforme descrição da tabela 3.2 , seguido da adição de $2 \%$ de ágar bacteriológico.

\subsection{Condições de cultivo dos microrganismos}

Os cultivos celulares de $S$. cerevisiae e $E$. coli foram realizados respectivamente a $30{ }^{\circ} \mathrm{C}$ e a $37^{\circ} \mathrm{C}$, em incubadora operando sob constante agitação à $170 \mathrm{rpm}$. As diferentes linhagens de $S$. cerevisiae e $E$. coli foram armazenadas em meio YPD líquido contendo glicerol $20 \%$ e estocadas à $-70^{\circ} \mathrm{C}$.

\subsection{Métodos gerais para manipulação de DNA}

A manipulação geral dos ácidos nucléicos, incluindo eletroforese de DNA, digestão com enzimas de restrição, ligação e purificação dos fragmentos de DNA, foi feita conforme descrito por Sambrook et al., (1989). 
TABELA 3.2 - Composição dos meios de cultura para o crescimento de $S$. cerevisiae e E. coli.

\begin{tabular}{|c|c|}
\hline \multicolumn{2}{|r|}{ Saccharomyces cerevisiae } \\
\hline Tipo de meio & Composição \\
\hline YPD & $1 \%$ extrato de levedura, $2 \%$ peptona e $2 \%$ glicose. \\
\hline YPEG & $1 \%$ extrato de levedura, $2 \%$ peptona, $3 \%$ glicerol e $2 \%$ etanol \\
\hline YPGal & $1 \%$ extrato de levedura, $2 \%$ peptona e $2 \%$ galactose. \\
\hline $\begin{array}{l}\text { Meio mínimo com } \\
\text { glicose (WO) }\end{array}$ & $\begin{array}{l}0,17 \% \text { base nitrogenada, } 0,5 \% \text { sulfato de amônio, } 2 \% \text { glicose, } \\
\text { suplementado, quando necessário, com os requerimentos } \\
\text { auxotróficos: adenina e uracila } 20 \mathrm{mg} / \mathrm{L} \text {, histidina, triptofano e } \\
\text { leucina } 10 \mathrm{mg} / \mathrm{L} \text {. }\end{array}$ \\
\hline $\begin{array}{c}\text { Meio para } \\
\text { esporulação (Kac) }\end{array}$ & $0,5 \%$ extrato de levedura, $1 \%$ acetato de amônio e $0,05 \%$ de glicose \\
\hline \multicolumn{2}{|r|}{ Escherichia coli } \\
\hline Tipo de meio & Composição \\
\hline Lauria-Bertani & $1 \%$ triptona, $0,5 \%$ extrato de levedura, $0,5 \% \mathrm{NaCL}$ e $0,1 \%$ de glicose \\
\hline $\begin{array}{l}\text { Lauria-Bertani com } \\
\text { ampicilina ( } \mathrm{L} \text { amp) }\end{array}$ & $\begin{array}{l}1 \% \text { triptona, } 0,5 \% \text { extrato de levedura, } 0,5 \% \mathrm{NaCL}, 0,1 \% \text { de glicose, } \\
\text { seguido da adição de ampicilina para concentração final de } \\
100 \mu \mathrm{g} / \mathrm{mL} \text {. }\end{array}$ \\
\hline
\end{tabular}

$O$ isolamento dos plasmídeos de $E$. coli em pequena escala foi feito segundo Birboim e Dolly (1979). Células bacterianas contendo o plasmídeo de interesse foram crescidas por aproximadamente 5-6 h em meio $L$ amp sólido contendo ampicilina $(100 \mu \mathrm{g} / \mathrm{mL})$ e em seguida transferidas para tubos de microcentrífuga de $1.5 \mathrm{~mL}$. Foram adicionados $100 \mu \mathrm{l}$ da solução I ou tampão de lise (glicose $50 \mathrm{mM}$, Tris-Cl $25 \mathrm{mM}(\mathrm{pH}=7,5)$, EDTA $10 \mathrm{mM}(\mathrm{pH}=7,5), 5 \mathrm{mg} / \mathrm{mL}$ de lisozima $\left(\right.$ Amresco $\left.{ }^{\circledR}\right), 200 \mu \mathrm{g} / \mathrm{mL}$ RNase) seguidos de $200 \mu \mathrm{l}$ da solução II $(\mathrm{NaOH}$ 0,2 $\mathrm{M}$ e SDS 1\%). A mistura foi então homogeneizada por inversão 5 vezes e após serem adicionados $150 \mu \mathrm{l}$ da solução III (acetato de amônio 7,5 M) a amostra foi centrifugada por $16.000 \times g$, por 5 min a temperatura ambiente. $O$ sobrenadante foi transferido para um tubo de microcentrífuga novo contendo 300 $\mu \mathrm{l}$ de isopropanol $100 \%$ e em seguida centrifugado como descrito acima. $O$ 
precipitado resultante contendo o DNA plasmidial foi lavado duas vezes com etanol $80 \%$, secado e ressuspendido em água ultrapura.

$O$ isolamento dos plasmídeos de E. coli em larga escala foi feito através do método de lise com triton. Células bacterianas contendo o plasmídeo de interesse foram cultivadas em placas de meio $L$ amp sólido contendo ampicilina $(100 \mu \mathrm{g} / \mathrm{mL})$ e em seguida transferidas para um tubo cônico de $15 \mathrm{~mL}$ estéril com auxílio de uma espátula. As células foram então ressuspendidas com $2 \mathrm{~mL}$ de tampão de lise (sacarose $5 \%$, Tris $50 \mathrm{mM}(\mathrm{pH}=8,0)$, EDTA 0,125 M, $5 \mathrm{mg}$ lisozima, $200 \mu \mathrm{g}$ de RNAse) e incubadas no gelo por 30 min. Após o período de incubação, foram adicionados $1 \mathrm{~mL}$ de solução $3 X$ TET (Triton X-100 10\%, EDTA 0,5 M (pH = 7,5), Tris $1 \mathrm{M}(\mathrm{pH}=8,0)$, seguida de uma centrifugação por $10 \mathrm{~min}$, a $4 \stackrel{\circ}{\circ}$, a 70.000 rpm em ultracentrífuga do tipo Beckman Optma TLX com rotor TLA 120.2. O sobrenadante foi então transferido para tubos cônicos de $15 \mathrm{~mL}$ e após a adição de um 1 volume de fenol saturado, a amostra foi homogeneizada e centrifugada à $1500 \times \mathrm{g}$, por $5 \mathrm{~min}$, a $4 \stackrel{\circ}{\circ}$. O sobrenadante foi transferido para um tubo novo de $15 \mathrm{~mL}$ e então adicionado 1 volume de clorofórmio/álcool isoamilico (24:1), misturado por inversão 5 vezes e novamente centrifugado à $1500 \times \mathrm{g}$, por $5 \mathrm{~min}$, a $4 \stackrel{\circ}{\circ}$. O DNA presente no sobrenadante foi precipitado com a adição de 1/20 volume de $\mathrm{NaCl} 5 \mathrm{M}$ e 3 volumes de álcool etílico $100 \%$. A solução foi centrifugada por $1500 \times \mathrm{g}$, por $5 \mathrm{~min}$, a $4 \stackrel{\circ}{\mathrm{C}}$, e $\mathrm{O}$ precipitado resultante (apresentando um aspecto oleoso), foi ressuspendido com 1,5 mL de acetato de

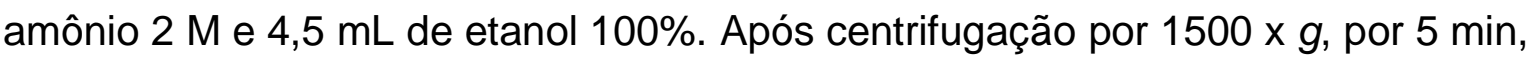
a $4 \stackrel{\circ}{\circ} \mathrm{C}$ o sobrenadante foi descartado e o precipitado foi lavado com $300 \mu \mathrm{l}$ de acetato de amônio $2 \mathrm{M}$, seguidos da adição de $1 \mathrm{~mL}$ de etanol $100 \%$ e posterior centrifugação por $16.000 \times \mathrm{g}$, por $5 \mathrm{~min}$ a temperatura ambiente. O precipitado resultante contendo o DNA plasmidial foi lavado duas vezes com etanol $80 \%$, secado e ressuspendido em água ultrapura.

A amplificação do DNA foi realizada através da reação em cadeia da polimerase (PCR) Sambrook et al., (1989). As reações de amplificação consistiram de $10 \mu \mathrm{L}$ de tampão da polimerase (10X) contendo $\mathrm{MgCl}_{2}$, cerca de $20 \mathrm{ng}$ de DNA molde, $200 \mathrm{nM}$ de dNTPs, 50 pmol de cada oligonucleotídeo iniciador, 5U Taq DNA polimerase (Biootols DNA Polymerase) e água ultrapura para um volume final de $100 \mu \mathrm{L}$. O programa utilizado para a amplificação 
consistiu de uma etapa inicial de desnaturação à $95^{\circ} \mathrm{C}$ por 5 min, seguidos de 34 ciclos de desnaturação $\left(95{ }^{\circ} \mathrm{C}\right)$, anelamento $\left(55^{\circ} \mathrm{C}\right)$, e extensão $\left(72{ }^{\circ} \mathrm{C}\right)$. Para garantir a completa extensão do DNA sintetizado foi acrescentada uma etapa a 72 oC por 10 minutos ao final do programa.

\subsection{Transformação das células de $E$. coli}

As células de E. coli foram tornadas competentes por tratamento com solução de cloreto de cálcio, para posterior transformação com a mistura de ligação (Sambrook et al.,1989).

\subsection{Transformação das células de S. cerevisiae}

As células de $S$. cerevisiae foram transformadas utilizando-se o método de acetato de lítio (Schiestl et al., 1989). Células de uma cultura na fase logarítmica de crescimento, foram coletadas por centrifugação a $600 \times \mathrm{g}$, por $5 \mathrm{~min}$, ressuspensas em solução de TEL (Tris $10 \mathrm{mM}(\mathrm{pH}=7,5)$, EDTA $1 \mathrm{mM}(\mathrm{pH}=7,5)$ acetato de lítio $0,1 \mathrm{M}$ ) e em seguida incubadas por $30 \mathrm{~min}$ em temperatura ambiente na presença de 5 ul de DNA de esperma de salmão desnaturado (10 $\mathrm{mg} / \mathrm{mL}$ - Sigma Aldrich) e $5 \mathrm{ul}$ de DNA transformante. Após este período, as células foram ressuspensas em $0,7 \mathrm{~mL}$ de solução de polietilenoglicol $40 \%$ (preparado em solução de TEL), e em seguida incubadas por $45 \mathrm{~min}$ a temperatura ambiente acompanhada de posterior incubação por 10 min a $42{ }^{\circ} \mathrm{C}$. As células foram então lavadas com $0,5 \mathrm{~mL}$ de tampão TE (Tris $10 \mathrm{mM}(\mathrm{pH}=7,5)$, EDTA $1 \mathrm{mM}$ ), centrifugadas por $16.000 \times \mathrm{g}$, por $30 \mathrm{seg}$, novamente ressuspensas em TE e finalmente semeadas em meio seletivo.

\subsection{Extração do DNA genômico de S. cerevisiae}

$O$ isolamento do DNA genômico de $S$. cerevisiae foi feito a partir de uma cultura celular crescida em $10 \mathrm{~mL}$ de meio YPD, a $30^{\circ} \mathrm{C}$, por um período de $16 \mathrm{~h}$. As células foram coletadas através de centrifugação por 5 min a $1500 \times \mathrm{g}$, a 25 ${ }^{\circ} \mathrm{C}$, lavadas com $1 \mathrm{~mL}$ de agua ultrapura e transferidas para tubos de microcentrífuga de $1.5 \mathrm{~mL}$. Após centrifugação a $16.000 \times \mathrm{g}$, por $30 \mathrm{seg}$, foram adicionados $1 \mathrm{~mL}$ de $\beta$-mercaptoetanol $1 \%$ e incubado por $10 \mathrm{~min}$ a temperatura ambiente. A mistura foi então centrifugada a $16.000 \times \mathrm{g}$, por $30 \mathrm{seg}$ e as células 
foram ressuspendidas com $0,5 \mathrm{~mL}$ de solução de sorbitol $1 \mathrm{M}$, EDTA 3,5 mM, fosfato de potássio $20 \mathrm{mM}(\mathrm{pH}=6,5)$ e $20 \mathrm{U}$ de zimoliase (a partir de Arthobacter luteus, 20.000 units.g ${ }^{-1}$, MP Biomedicals). Após incubação por $30 \mathrm{~min}$ a $37{ }^{\circ} \mathrm{C}$, foram adicionados $0,3 \mathrm{~mL}$ de solução contendo TritonX-100 2\%, SDS $1 \%, \mathrm{NaCl}$ $100 \mathrm{mM}$, Tris- $\mathrm{Cl} 100 \mathrm{mM}$ ( $\mathrm{pH}=8.0$ ) e EDTA $1 \mathrm{mM}$. A mistura foi homogeneizada por inversão 5 vezes e incubada por $20 \mathrm{~min}$ a $65 \stackrel{\circ}{\circ}$. Após o período de incubação, foram adicionados 1 volume de fenol-clorofórmio-álcool isoamílico (24:24:1), homogeneizado por inversão 5 vezes e centrifugado por $5 \mathrm{~min}$, a $16.000 \times \mathrm{g}$. O sobrenadante foi transferido para tubo novo, adicionado 1 volume de clorofórmio-álcool isoamílico (24:1), homogeneizado por inversão e centrifugado por $5 \mathrm{~min}$, a $16.000 \times \mathrm{g}$. O sobrenadante contendo o DNA genômico foi transferido para um tubo e o DNA foi precipitado através da adição de 1/20 volume de $\mathrm{NaCl} 5 \mathrm{M}$ seguido de 2, 5 volumes de etanol $100 \%$. A mistura foi centrifugada por $10 \mathrm{~min}$, a $16.000 \times \mathrm{g}$, lavada duas vezes com etanol $80 \%$, secada e ressupendida com $50 \mu \mathrm{L}$ de água ultrapura.

\subsection{Determinação da estabilidade do mtDNA}

A determinação da estabilidade do genoma mitocondrial (mtDNA) nas diferentes linhagens de $S$. cerevisiae foram feitas através de análises da frequência de aparecimento de colônias petites incapazes de crescer em meio seletivo para a atividade respiratória.

Para determinar a taxa de formação de colônias petites, culturas das linhagens a serem testadas foram crescidas em $10 \mathrm{~mL}$ de meio YPD por um período de aproximadamente $10 \mathrm{~h}$. Esta cultura foi então diluída para uma $\mathrm{Abs}_{600}$ final de 0,01 em $10 \mathrm{~mL}$ de meio YPD fresco e em seguida crescida por $16 \mathrm{~h}$. Nestas condições, ainda observa-se a presença de glicose no meio de cultura, conforme verificado por analises de HPLC realizadas por Tahara e colaboradores (TAHARA et al., 2007). A presença de glicose no meio de cultura se torna necessário pelo fato de que na ausência desse açúcar o crescimento dos mutantes petites é interrompido, devido a incapacidade dessas células realizarem metabolismo espiratório. Isto poderia causar estimativas errôneas da verdadeira taxa de geração de colônias petites na população de levedura analisada. 
Após o período de crescimento, amostras de cada cultura foram diluídas, plaqueadas em placas de meio YPD sólido e em seguida crescidas por 2 a 3 dias em estufa a $30^{\circ} \mathrm{C}$. O número de colônias para cada placa (100 a 200 colônias/placa) foi então determinado e a porcentagem de colônias petites foi calculada como se segue: número de colônias petites x 100 / número total de colônias contadas nas placas. A distinção entre as colônias petites e as colônias competentes respiratórias foi feita através de cruzamentos com linhagens testes desprovidas de mtDNA seguido da seleção dos diploides em meio seletivo para a atividade respiratória.

\subsection{Ensaio de resistência a eritromicina}

As condições do ensaio de resistência a eritromicina foram adaptadas a partir do protocolo de Chi e Kolodner (1994). Células a partir de uma cultura crescida por $16 \mathrm{~h}$ a $30 \stackrel{\circ}{\circ} \mathrm{em}$ meio seletivo para a atividade respiratória (EG) foram inoculadas em $10 \mathrm{~mL}$ de meio YPD ou YPGal para uma densidade óptica (D.O.600) final de 0,1. Após o período de crescimento, uma quantidade de células equivalente a uma densidade óptica (D.O.600) 10 foram plaqueadas em placas de meio $E G$ contendo eritromicina ( $1 \mathrm{mg} / \mathrm{mL})$ e em seguida crescidas a $30 \stackrel{\circ}{\circ}$ por $4-5$ dias. Adicionalmente uma pequena amostra de cada cultura foi removida e plaqueada em placas de meio EG para determinar o numero total de células competentes-respiratórias. A frequência de mutação foi calculada da seguinte maneira: número de colônias resistentes a eritromicina / número total de colônias plaqueadas.

\subsection{Isolamento de mitocôndrias de S. cerevisiae - método da zimoliase}

$O$ isolamento de mitocôndrias a partir das linhagens de $S$. cerevisiae foi feito segundo Faye et al., (1974). Células a partir de uma cultura crescida em meio YPGAl por aproximadamente $24 \mathrm{~h}$, foram inicialmente centrifugadas a $900 \mathrm{x}$ $g$ por 5 min a $4 \stackrel{\circ}{\circ}$, suspendidas com sorbitol $1,2 \mathrm{M}$ e novamente centrifugadas a $900 \times \mathrm{g}$ por $10 \mathrm{~min}$ a $4 \stackrel{\circ}{\circ} \mathrm{C}$. O precipitado resultante foi então pesado e em seguida ressuspendido com $3 \mathrm{~mL}$, para cada grama de células, de tampão de digestão contendo sorbitol $2 \mathrm{M}$, fosfato de sódio $0,5 \mathrm{M}(\mathrm{pH}=7,5)$, EDTA $0,5 \mathrm{M}, \beta$ mercaptoetanol $1 \%$, $\left(\operatorname{Merck}^{\circledR}\right.$ ) e zimoliase $1 \mathrm{mg} / \mathrm{mL}$ ( a partir de Arthobacter luteus, 
20.000 units. $\mathrm{g}^{-1}$, MP Biomedicals). A suspensão resultante foi então incubada com moderada agitação orbital (50rpm), a $37 \stackrel{\circ}{ } \mathrm{C}$, por 2 horas. Durante esta etapa, ocorre a digestão da parede celular fúngica e consequentemente a geração dos esferoplastos.

Ao término do período de incubação, a reação de digestão foi interrompida através da incubação das amostras no gelo. Os esferoplastos foram então lavados com sorbitol 1,2 $\mathrm{M}$ e em seguida centrifugados a $4600 \times \mathrm{g}$, por $10 \mathrm{~min}$ a 4 ○C. O processo foi repetido. $O$ precipitado resultante foi ressuspendido em tampão sorbitol 0,6 M, Tris-Cl $10 \mathrm{mM}(\mathrm{pH}=7,5)$, EDTA $1 \mathrm{mM}$, na presença de PMSF 8 $\mu \mathrm{M}$, como inibidor de protease, utilizando-se o mesmo volume empregado na reação de digestão. A suspensão de esferoplastos foi então submetida a duas etapas de agitação mecânica: uma agitação suave através de um homogeneizador do tipo potter, por aproximadamente 1 min e outra mais forte com auxílio de um agitador mecânico, durante 40 segundos. Após centrifugação por $1500 \times \mathrm{g}$, por $5 \mathrm{~min}$, a $4 \stackrel{\circ}{\circ} \mathrm{C}$, o sobrenadante foi transferido para tubos cônicos de centrífuga previamente gelados e em seguida submetido a centrifugação à $18000 \times \mathrm{g}$, por $10 \mathrm{~min}$, a $4 \stackrel{\circ}{\circ} \mathrm{C}$. O precipitado resultante, representando a fração mitocondrial, foi ressuspendido em $2 \mathrm{~mL}$ de tampão sorbitol 0,6 M, Tris-Cl $10 \mathrm{mM}$ $(\mathrm{pH}=7,5)$, EDTA $1 \mathrm{mM}$ e novamente centrifugado à $18000 \times \mathrm{g}$, por $10 \mathrm{~min}$, a $4 \stackrel{\circ}{\circ} \mathrm{C}$. Este processo foi repetido mais 3 vezes. Por fim, a fração mitocondrial foi ressuspendida em $500 \mu \mathrm{L}$ de tampão sorbitol $0,6 \mathrm{M}$, Tris- $\mathrm{Cl} 10 \mathrm{mM}(\mathrm{pH}=7,5)$, EDTA $1 \mathrm{mM}$. A quantificação de proteínas se deu pelo método de Lowry (Lowry, 1959).

\subsection{Análise das proteínas mitocondriais: Eletroforese em gel de poliacrilamida em condição desnaturante (SDS-PAGE) seguido de western blot}

As análises eletroforéticas de proteínas mitocondriais em gel de poliacrilamida em condição desnaturante foram feitas como descrito por Laemmli (1970) usando sistema de minigéis. A porcentagem de acrilamida dos géis de separação e de empilhamento foram $12 \%$ e $6 \%$, respectivamente. O gel de separação foi preparado com $0,75 \mathrm{~mL}$ de Tris-Cl $3 \mathrm{M}$, (pH 8.8), 2,4 $\mathrm{mL}$ de acrilamida-bis 30:0.8, $60 \mu \mathrm{L}$ de SDS 10\%, $20 \mu \mathrm{L}$ de persulfato de amônio 10\%, 5 
$\mu \mathrm{l}$ TEMED e 2,76 $\mathrm{mL}$ de água, para um volume final de $6 \mathrm{~mL}$. Para o gel de empacotamento utilizou-se $0,25 \mathrm{~mL}$ de Tris-Cl $3 \mathrm{M}(\mathrm{pH}=6,8) ; 0,4 \mathrm{~mL}$ de acrilamida-bis $30: 0.8,20 \mu \mathrm{L}$ de SDS $10 \%, 0,01 \mathrm{~mL}$ de persulfato de amônio $10 \%$, $3 \mu \mathrm{I}$ TEMED e 1,32 $\mathrm{ml}$ de água, para um volume final de $2 \mathrm{~mL}$.

Antes de serem analisadas por SDS-PAGE, as amostras de proteínas mitocondriais $(200 \mu \mathrm{g})$, foram misturadas com 12,5 $\mu \mathrm{L}$ de tampão $4 \mathrm{xL}(2 \mathrm{~mL}$ de Tris-Cl $1 \mathrm{M}(\mathrm{pH}=6,8), 4 \mathrm{~mL}$ de SDS $10 \%, 4 \mathrm{~mL}$ de glicerol, $0,4 \mathrm{~mL}$ de mercaptoetanol; $0,01 \%$ e 0,01\% de azul brilhante), $1 \mu \mathrm{L}$ de PMSF $100 \mathrm{mM}$ e água para um volume final de $50 \mu \mathrm{L}$. As eletroforeses foram realizadas a $160 \mathrm{~V}$ em tampão 1X ETB (Tris 3,03\%; glicina 14,4\%; SDS 1\%).

Após a corrida eletroforética, as proteínas mitocondriais foram transferidas para uma membrana de nitrocelulose utilizando o sistema de transferência semiseco. O processo de transferência consistiu em colocar o gel de poliacrilamida em contato com a membrana de nitrocelulose envoltos com duas folhas de papel absorvente, todos umedecidos em solução de WTB (glicina 1,437\%, Tris $0,3 \%$; metanol 20\%) A transferência foi realizada em $100 \mathrm{~mA}$ por 30 min. Após este período, a membrana de nitrocelulose foi corada com solução Ponceau (Ponceau $0,2 \%$, ácido tricloroacético $3 \%$, ácido sulfosalićlico $3 \%$ ) a fim de comprovar a eficiência do processo de transferência e evidenciar as bandas do padrão de peso molecular. Posteriormente, a membrana foi bloqueada com solução de leite desnaturado $5 \%$ durante $1 \mathrm{~h}$, seguida de incubação com o anticorpo primário (1:1000) por um período de $1 \mathrm{~h}$. A membrana foi então lavada três vezes com solução de $\mathrm{NaCl} 150 \mathrm{mM}$, Tris- $\mathrm{HCl} 10 \mathrm{mM}$, Triton 0,1\%, por um período de $10 \mathrm{~min}$ e em seguida incubada com o anticorpo secundário (1:5000), durante uma hora. Por fim, membrana foi novamente lavada 3 vezes com solução de $\mathrm{NaCl} 150 \mathrm{mM}$, Tris- $\mathrm{HCl} 10 \mathrm{mM}$, Triton 0,1\%, por um período de $10 \mathrm{~min}$. Os complexos antígenoanticorpo foram visualizados através da exposição da membrana em um filme de raio-X, após lavagem da mesma com solução 1:1 de SuperSignal ${ }^{\circledR}$ West Pico Luminol/Enhancer Solution e SuperSignal ${ }^{\circledR}$ West Pico Stable/Peroxide Solution (Thermo Scientific). 


\subsection{Medidas do consumo de oxigênio}

As taxas de consumo de oxigênio das mitocôndrias isoladas foram determinadas com o uso de um eletrodo de Clark (Hansatech Instruments, modelo A1STIR) conectado a um computador e operando com agitação contínua, à $30 \stackrel{\circ}{\circ}$. O sistema de reação consistiu de suspensões mitocondriais $(100 \mu \mathrm{g} / \mathrm{mL})$ em tampão fosfato de potássio $10 \mathrm{mM}(\mathrm{pH}$ 7.5) na presença de NADH $1 \mu \mathrm{M}$ como substrato respiratório.

\subsection{Medida da liberação de peróxido de hidrogênio em mitocôndrias isoladas de $S$. cerevisiae}

A liberação de peróxido de hidrogênio a partir de mitocôndrias isoladas de S. cerevisiae foi monitorada por 10 minutos através da oxidação de $50 \mu \mathrm{M}$ de Amplex $^{\mathrm{TM}}$ Red (Molecular Probes ${ }^{\circledR}$ ) na presença de 1,0 U/mL de peroxidase de raiz forte $\left(\right.$ Sigma $\left.{ }^{\circledR}\right)$, com o uso de um espectrofotômetro de fluorescência Hitachi F-4500, operando com comprimentos de onda de 563nm de excitação e 587nm de emissão, sob agitação constante, a $30 \stackrel{\circ}{\circ}$. O sistema de reação era composto de suspensões de mitocondrias $(100 \mu \mathrm{g} / \mathrm{mL})$ em tampão contendo $0,6 \mathrm{M}$ de sorbitol, $20 \mathrm{mM}$ Tris- $\mathrm{HCl} \mathrm{pH}=7,5$ e 0,5 mM EDTA na presença dos seguintes substratos respiratórios: etanol $(2 \%)$, malato $1 \mathrm{mM}(\mathrm{pH}=7.5)$, e glutamato $1 \mathrm{mM}$ $(\mathrm{pH}=7.5)$. Quando necessário, a inibição da cadeia respiratória foi feita através da adição de Antimicina $A$, em uma concentração final de $0,5 \mu \mathrm{g} / \mathrm{mL}$.

\subsection{Construção de mutantes nulos - metodologia geral}

Mutantes nulos de $S$. cerevisiae foram gerados através da substituição da região codificadora dos genes de interesse com um gene repórter, através da técnica de interrupção gênica em etapa única (JOHNSTON et al., 2002). Inicialmente as regiões codificadoras dos genes de interesse foram amplificadas através da técnica de reação em cadeia da polimerase (PCR) utilizando-se os oligonucleotídeos (primers) descritos na tabela 3. Os fragmentos resultantes foram purificados e ligados nos vetores de clonagem Yep352 (para os genes NDE1 e NDI1) e Yip352 (para o gene NDE2). (HILL et al., 1986). As moléculas recombinantes foram então utilizadas para promover a inserção do gene repórter no interior da sequência codificadora. Para isto, a região central do gene a ser 
interrompido foi removida com auxílio de enzimas de restrição e o gene repórter foi inserido no lugar da sequencia removida. A região contendo o gene repórter flanqueado pelas sequencias $\mathrm{C}$ e $\mathrm{N}$-terminais do gene de interesse foi posteriormente liberado do vetor de clonagem e em seguida utilizado para transformar linhagens haplóides de $S$. cerevisiae. Durante o processo de transformação, o sistema de recombinação homóloga da levedura reconhece a homologia de sequência presente nas extremidades da molécula transformada e o gene selvagem no genoma, promovendo assim a substituição do gene selvagem pelo gene interrompido.

A verificação da interrupção gênica foi feita por meio da técnica de PCR seguida pela digestão dos fragmentos resultantes com enzimas de restrição apropriadas.

Mutantes duplos e triplos foram gerados pelo cruzamento de mutantes simples de tipos de acasalamentos opostos. Os diploides resultantes foram então esporulados em meio Kac e após a dissecção das tétrades, os mutantes duplos e triplos foram selecionados em meio mínimo respeitando a marca de seleção conferida pelos genes repórteres inicialmente utilizados para construir os mutantes simples, como também observando-se a segregação Mendeliana das marcas em heterozigose conhecidas.

\section{TABELA 3 - Oligonucleotídeos utilizados nesse trabalho}

\begin{tabular}{cc}
\hline Oligonucleotídeos & Sequência de Nucleotídeos \\
\hline $\begin{array}{c}\text { Amplificação dos genes das } \\
\text { NADH desidrogenases }\end{array}$ \\
\hline NDE1-1 \\
NDE1-2 \\
NDE2-1 \\
NDE2-2 \\
NDI1-1 \\
NDI1-1 \\
GGCGGGGATCCCGGATGGCCGGGTAAA \\
GGCGGATCCCTCTAGCTACTATATC \\
GGCCTGCAGCGGCAATTGCCACTGGGC \\
GGCCTGCAGGAAAAAACGGTGCC
\end{tabular}




\section{RESULTADOS E DISCUSSÃO PARCIAL}

\subsection{Avaliação da instabilidade do mtDNA em diferentes mutantes respiratórios de $S$. cerevisiae}

A fim de compreender os mecanismos pelos quais o mutante $\Delta$ coq10 produz elevada quantidade de células petites, inicialmente procuramos avaliar a estabilidade do mtDNA em diferentes mutantes respiratórios de $S$. cerevisiae, com o objetivo de verificar se haveria diferença significativa entre eles no que tange a estabilidade do mtDNA. Para isto, mutantes envolvidos no metabolismo da coenzima $Q$ e na montagem dos complexos respiratórios III e IV foram agrupados e avaliados em relação à estabilidade do mtDNA, através de medidas da frequência de formação de colônias petites.

A Figura 2 demonstra que os mutantes coq, envolvidos na expressão funcional da coenzima $Q$, apresentaram maior taxa de formação de colônias petites em relação aos mutantes envolvidos na montagem dos complexos respiratórios III (cor1 $\Delta$, bcs $1 \Delta$ e rip $1 \Delta)$ e IV $(\operatorname{cox} 11 \Delta, \operatorname{cox} 15 \Delta$ e $\operatorname{cox} 17 \Delta)$. A maior instabilidade do mtDNA nos mutantes coq deve estar relacionada a maior geração do radical superóxido pelas NADH desidrogenases mitocondriais que se manteriam no estado reduzido (DAVIDSON; SCHIESTL, 2001), bem como por um papel mais direto da coenzima $Q$ como antioxidante (BENTINGER et al., 2007).

Dentre os mutantes coq, $\Delta$ coq10 foi o que apresentou a maior taxa de formação de colônias petites, conforme detectado anteriormente (BARROS et al., 2005). Curiosamente, ao contrário de coq2 $\Delta$ e coq $4 \Delta$, o mutante coq10 $\Delta$ apresenta níveis normais de coenzima Q (BARROS et al., 2005) e paradoxalmente foi o que apresentou a maior taxa de formação de petites.

No interior da célula, a coenzima $Q$ está presente em praticamente todas as membranas celulares (TURUNEN et al., 2004). Durante sua ação na cadeia respiratória mitocondrial, a coenzima $Q$ existe na forma de um pool, contrabalançando entre as formas: completamente oxidada (ubiquinona), parcialmente reduzida (semiquinona) e totalmente reduzida (ubiquinol) (LENAZ; GENOVA, 2009). É possível que no mutante $\Delta$ coq10 ocorra um desbalanço entre essas formas e consequente aumento da coenzima $Q$ reduzida, visto que nesse mutante o transporte eletrônico dependente de CoQ está interrompido, isto é, os 
Figura 2 - Frequência de geração de colônias petites em diferentes mutantes respiratórios de S. cerevisiae.

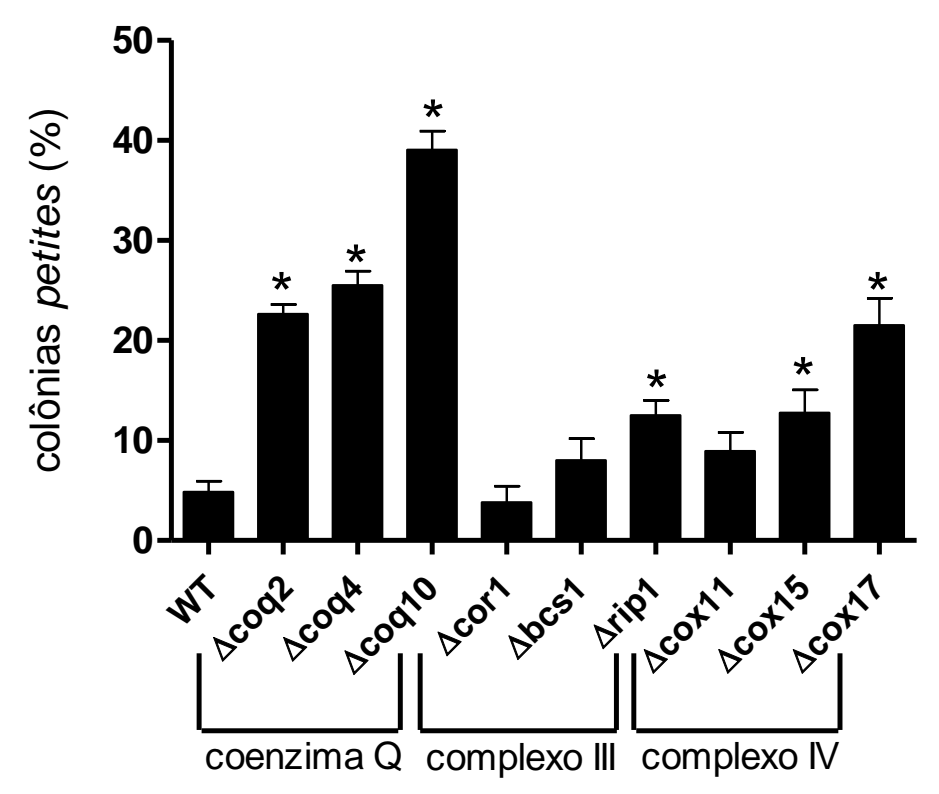

A determinação da porcentagem de colônias petites foi realizada conforme descrição em Materiais e Métodos (Item 3.8). $\left({ }^{*}\right)$ Valores de $P<0.05$ vs. WT.

elétrons não chegam ao citocromo $c$ (BARROS et al., 2005). Mas, curiosamente, chegam ao citocromo $b \mathrm{~L}$, pois o mutante $\Delta \operatorname{coq} 10$ se mostrou responsivo a inibição com antimicina A (BUSSO et al., 2010b). Como consequência desse desbalanço da coenzima $Q$ haveria uma maior taxa de redução monoeletrônica do oxigênio molecular elevando a geração de espécies reativas de oxigênio (EROs). Este aumento na produção de EROs ocasionaria um aumento de danos oxidativos em proteínas, lipídeos e ácidos nucleicos (revisto em KOWALTOWSKI et al., 2009).

Para avaliar esta hipótese, procuramos alterar o estado redox da coenzima $Q$ na linhagem $\Delta$ coq10. Para isto, inativamos as enzimas responsáveis pela redução da coenzima $Q$ em $S$. cerevisiae. $O$ mesmo procedimento foi para as linhagens WT e $\Delta c o q 4$, as quais foram utilizadas como controles positivo e negativo para a síntese da coenzima $Q$, respectivamente. A linhagem $\Delta c o q 4$ foi escolhida como controle negativo para CoQ, pois, ao contrário de WT e $\Delta \operatorname{coq} 10$, é incapaz de promover a síntese de coenzima Q (BELOGRUDOV et al., 2001). 


\subsection{Construção de mutantes nulos para as NADH desidrogenases mitocondriais}

A inativação das enzimas que fornecem elétrons para a coenzima $Q$ em $S$. cerevisiae foi feita através da técnica de interrupção gênica em etapa única (Materiais e Métodos, item 3.13). Inicialmente foram construídos mutantes simples para cada uma das NADH desidrogenase individuais. No total, foram inativadas as enzimas NADH desidrogenase interna (Ndi1p), responsável pela oxidação do $\mathrm{NADH}$ intramitocondrial e, NADH desidrogenases externas Nde1p e Nde2p, ambas envolvidas na oxidação do NADH citosólico (BAKKER et al., 2001). Após a construção dos mutantes simples, as inativações gênicas foram combinadas através do cruzamento entre as linhagens que continham as inativações gênicas individuais. Dessa maneira, obtiveram-se mutantes duplos e triplos para as NADH desidrogenases.

A fim de confirmar a inativação das NADH desidrogenases, mitocôndrias extraídas das linhagens mutantes foram ensaiadas quanto a sua capacidade respiratória dependente de $\mathrm{NADH}$. A atividade respiratória foi avaliada através do monitoramento polarográfico do consumo de oxigênio das mitocôndrias extraídas, utilizando-se um eletrodo de oxigênio do tipo CLARK (Materiais e Métodos, item 3.11).

As análises de consumo de oxigênio demonstram que a linhagem selvagem WT, assim como a linhagem mutante $\Delta n d i 1$ apresentaram elevada taxa respiratória dependente da adição de NADH exógeno (Figura 3). Isto demonstra que as mitocôndrias isoladas foram capazes de acoplar a oxidação do NADH com a cadeia respiratória, através das NADH desidrogenases externas. Apesar da inativação de Nde2p não ter alterado a atividade respiratória, a ausência de Nde1p provocou uma queda de 4-5 vezes no consumo de oxigênio dependente de NADH (Figura 3). Quando ambas as NADH desidrogenases externas foram inativadas, o consumo de oxigênio pelas mitocôndrias isoladas foi drasticamente reduzido (Figura 3). Resultados semelhantes foram reportados por Luttik e colaboradores (1998), demonstrando que a enzima Nde1p é a principal responsável pela oxidação do NADH citosólico (BAKKER et al., 2001). A atividade respiratória residual observada para o duplo mutante $\Delta$ nde1 $\Delta$ nde2 pode ser em 
decorrência da exposição da NADH desidrogenase interna devido à presença de uma parcela de mitocôndrias danificadas.

Figura 3 - Medida do consumo de oxigênio das mitocôndrias isoladas dos mutantes das NADH desidrogenases.
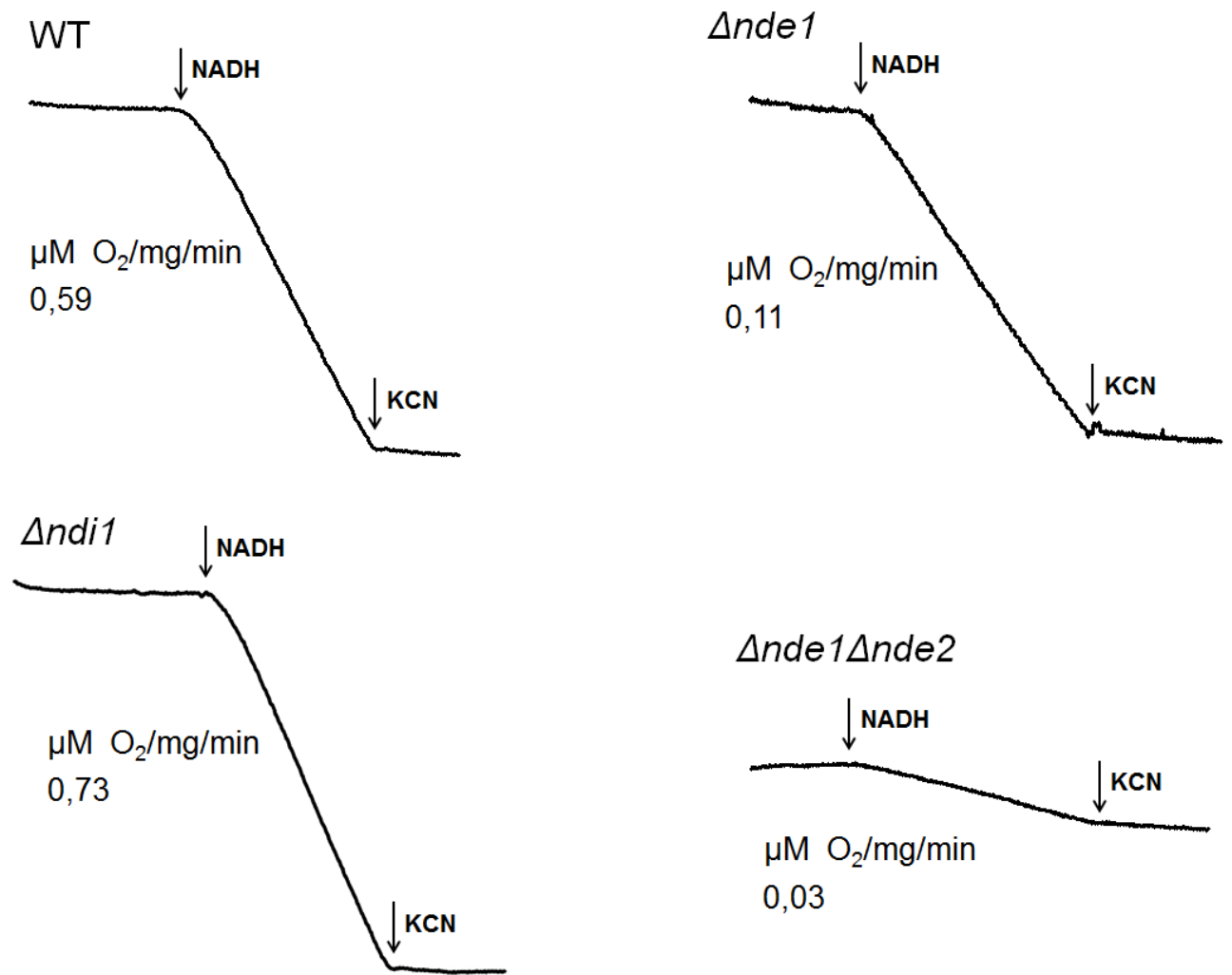

$\Delta n d e 1 \Delta n d e 2$
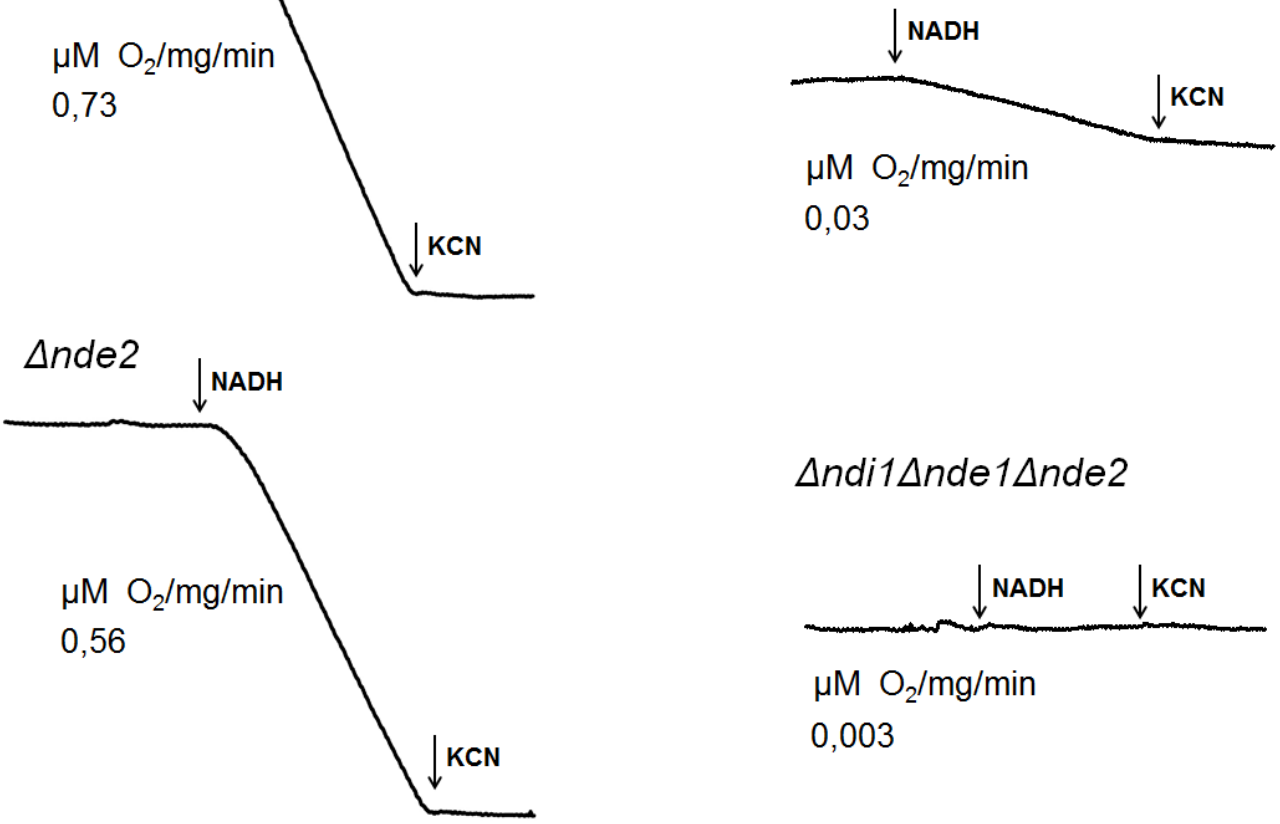

$\Delta n d i 1 \Delta n d e 1 \Delta n d e 2$

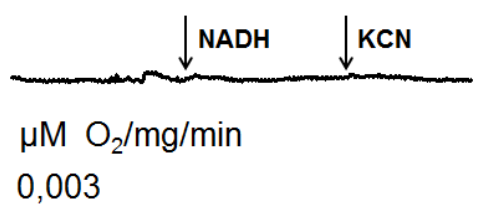

Determinação do consumo de oxigênio em mitocôndrias $(100 \mu \mathrm{g} / \mathrm{mL})$ isoladas das linhagens WT, $\Delta$ ndi1, $\Delta$ nde1, $\Delta$ nde2, $\Delta$ nde1 $\Delta$ nde2 e $\Delta$ ndi1 $\Delta n d e 1 \Delta n d e 2$ induzida por $\mathrm{NADH} 1 \mu \mathrm{M}$ foi realizada segundo descrição em Materiais e Métodos, (Item 3.12). As setas indicam o momento da adição do substrato respiratório NADH e o inibidor da citocromo $c$ oxidase $\mathrm{KCN}$. 
Figura 4 - Propriedades de crescimento das linhagens WT, $\Delta c o q 10$ e $\Delta c o q 4$, em combinação com a inativação das diferentes NADH desidrogenases mitocondriais.

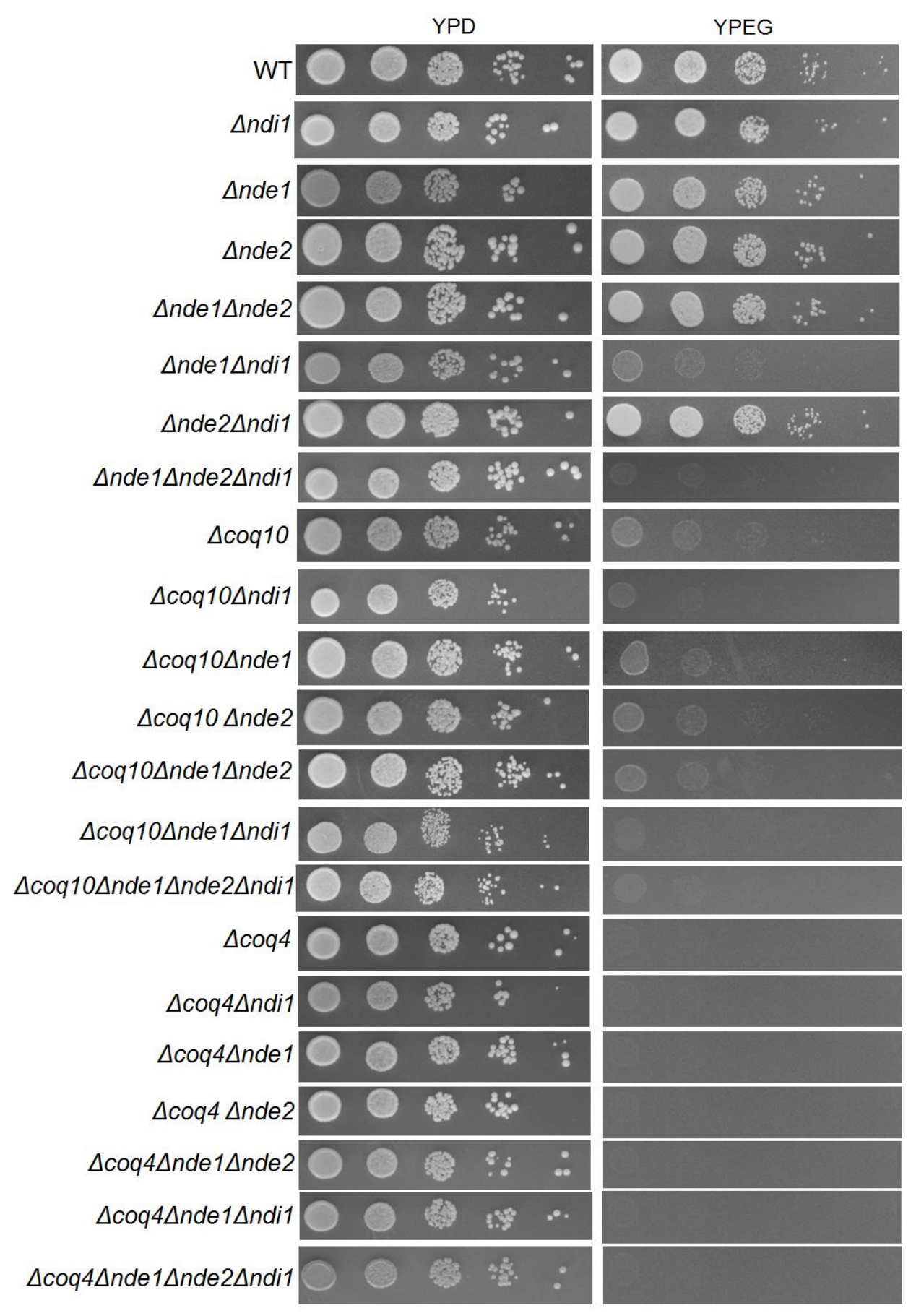

As diferentes linhagens foram crescidas em meio rico (YPD) por $16 \mathrm{~h}$, e após a absorbância a $600 \mathrm{~nm}\left(\mathrm{Abs}_{600}\right)$ ser ajustada para 1, 0,1, 0,01, 0,001 e 0,0001, as células foram plaqueadas em placas contendo meio rico fermentativo (YPD) e meio seletivo para a atividade respiratória (YPEG) e em seguida incubadas a $30 \stackrel{\circ}{ } \mathrm{C}$, por 48 horas. 
Após a confirmação da inativação das NADH desidrogenases na linhagem selvagem, procuramos introduzir a mutação dessas enzimas nas linhagens $\Delta c o q 10$ e $\Delta c o q 4$. Através de sucessivos cruzamentos entre as linhagens $\Delta c o q 10$ e $\triangle$ coq 4 com os mutantes simples para as NADH desidrogenases mitocondriais, foi possível obter mutantes simples, duplos e triplos das NADH desidrogenases em combinação com $\Delta \operatorname{coq} 10$ e $\Delta c o q 4$. Em seguida, avaliamos as propriedades de crescimento dessas linhagens em diferentes fontes de carbono.

A inativação das NADH desidrogenases individuais na linhagem de referência W303, não alterou as propriedades de crescimento em meio não fermentativo. O mesmo foi observado para o duplo mutante $\Delta$ nde1 $\Delta$ nde2. Entretanto, o crescimento do duplo mutante $\Delta$ nde1 $\Delta$ ndi1 foi severamente prejudicado, ao passo que no triplo mutante $\Delta$ nde1 $\Delta$ nde2 $\Delta$ ndi1, foi completamente abolido (Figura 4). Analisados em conjunto, os resultados indicam que as enzimas Nde1p e Ndi1p desempenham papéis essenciais na oxidação do NADH citosólico e intramitocondrial, respectivamente (BAKKER et at., 2001)

Conforme anteriormente verificado (BARROS et al., 2005), o mutante $\Delta$ coq10 cresceu lentamente em meio contendo etanol/glicerol, uma fonte de carbono não fermentável (Figura 4). De modo semelhante ao ocorrido na linhagem W303, a inativação das enzimas Nde1p e Ndi1p aboliu completamente o crescimento residual do mutante $\Delta \operatorname{coq} 10$. A linhagem $\Delta c o q 4$, deficiente na síntese da coenzima $Q$, apresentou crescimento completamente nulo em meio não fermentativo, uma característica dos mutantes coq de levedura (TRAN; CLARK, 2007).

\subsection{Avaliação da liberação de peróxido de hidrogênio nas linhagens WT, $\Delta$ coq10 e $\Delta$ coq4 em combinação com a inativação das NADH desidrogenases mitocondriais.}

A inativação das diferentes $\mathrm{NADH}$ desidrogenases mitocondriais na linhagem $\Delta$ coq10 teve por objetivo diminuir o fornecimento de elétrons para a coenzima $Q$ e consequentemente promover uma redução na geração de EROs. Desta forma, procuramos avaliar os níveis de estresse oxidativo nas diferentes linhagens através do monitoramento da formação de peróxido de hidrogênio 
$\left(\mathrm{H}_{2} \mathrm{O}_{2}\right)$. A geração de $\mathrm{H}_{2} \mathrm{O}_{2}$ foi avaliada em suspensões de mitocôndrias isoladas das diferentes linhagens, usando um método fluorométrico, no qual a sonda Amplex Red, na presença de $\mathrm{HRP}$, reage com $\mathrm{H}_{2} \mathrm{O}_{2}$ com uma estequiometria 1:1 produzindo um composto altamente fluorescente, a resorufina ( $\mathrm{ZHOU}$ et al., 1997).

A Figura $5 \mathrm{~A}$ demonstra que as taxas de liberação de $\mathrm{H}_{2} \mathrm{O}_{2}$ a partir das mitocôndrias isoladas da linhagem selvagem foram significativamente similares em relação aos mutantes simples para as NADH desidrogenases $\Delta n d e 1$ e $\Delta n d e 2$, bem como para o mutante duplo $\Delta n d e 1 \Delta n d e 2$. Em todos os casos, a adição de antimicina $A$, resultou em uma produção aumentada de $\mathrm{H}_{2} \mathrm{O}_{2}$, indicando a existência de um ciclo $Q$ ativo nessas linhagens. $A$ antimicina $A$ atua como um inibidor do complexo respiratório III, ligando-se especificamente no sítio $Q_{i}$ deste complexo (WIKSTRÖM; BERDEN, 1972; DRÖES; BRANDT, 2008). Isto desencadeia a geração de grandes quantidades do radical superóxido devido a reação do oxigênio molecular com a ubisemiquinona ligada no sítio $Q_{0}$ desse complexo (CADENAS et al., 1977; TURENS ET AL., 1985; DRÖES; BRANDT, 2008).

Por outro lado, o mutante simples $\Delta$ ndi1 e o triplo mutante $\Delta n d i 1 \Delta n d e 1 \Delta n d e 2$, liberaram 2-3 vezes mais peróxido de hidrogênio em relação a linhagem selvagem. (Figura 5A). Além disso, essas linhagens não responderam a inibição com antimicina $A$, indicando a inexistência de um fluxo de elétrons para 0 complexo III. Desta forma, a elevada produção de $\mathrm{H}_{2} \mathrm{O}_{2}$ observado para $\Delta n d i 1$ e $\Delta n d i 1 \Delta n d e 1 \Delta n d e 2$ provavelmente não é em decorrência da atividade da cadeia respiratória e sim devido a enzimas presentes na matriz, que se manteriam no estado reduzido devido a não oxidação do NADH mitocondrial. De fato, em 2007, Tahara e colaboradores demonstraram que enzimas contendo a subunidade da flavoenzima diidrolipoil desidrogenase, como por exemplo, o complexo da $\alpha$ cetoglutarato desidrogense e piruvato desidrogenase, são responsáveis pela geração de quantidades significativas de peróxido de hidrogênio em S. cerevisiae. (TARAHA et al., 2007). 
Figura 5 - Medidas da liberação de peróxido de hidrogênio $\left(\mathrm{H}_{2} \mathrm{O}_{2}\right)$ em mitocôndrias isoladas de diferentes linhagens de $S$. cerevisiae.

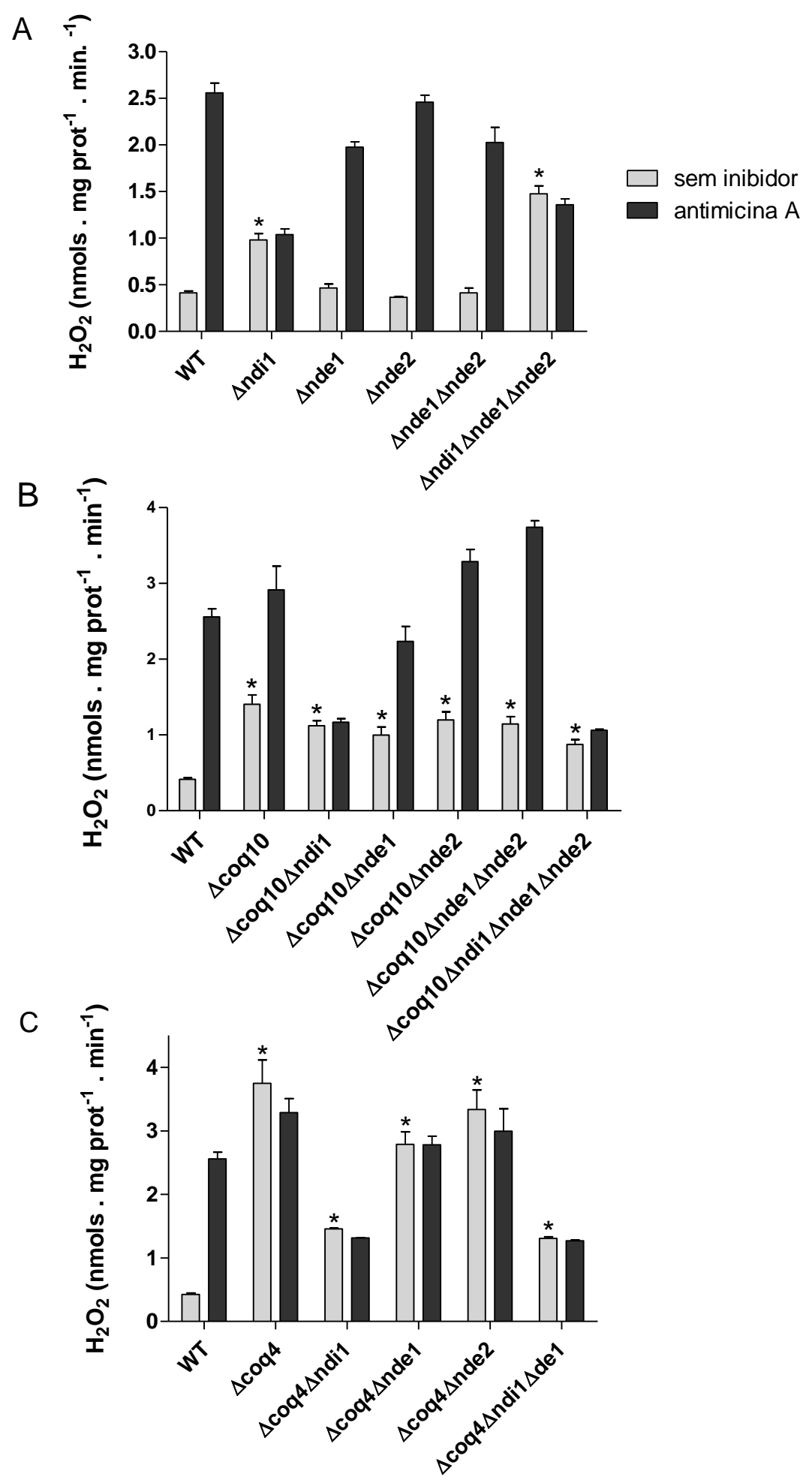

A determinação da liberação de $\mathrm{H}_{2} \mathrm{O}_{2}$ em suspensões mitocondriais $(100 \mu / \mathrm{mL})$ induzida por etanol $2 \%$, glutamato $1 \mathrm{mM}$ e malato $1 \mathrm{mM}$, foi realizada conforme descrito em Materiais e Métodos (Item 3.13). $\left({ }^{*}\right)$ Valores de $P<0.01$ versus WT. 
A liberação de peróxido de hidrogênio a partir das mitocondriais isoladas da linhagem $\Delta \operatorname{coq} 10$ foi significativamente maior que a linhagem selvagem (Figura 5B), conforme anteriormente verificado por Busso e colaboradores (2010b). Entretanto, esses autores observaram uma produção de peróxido relativamente maior para a linhagem $\Delta \operatorname{coq} 10$ em relação aos resultados reportados neste trabalho. A inativação individual das NADH desidrogenases Ndi1p, Nde1p e Nde2 $p$ não diminuiu a taxa de liberação de $\mathrm{H}_{2} \mathrm{O}_{2}$ do mutante $\Delta$ coq10. O mesmo foi observado quando ambas as enzimas externas foram inativadas. Acreditamos que a ausência na diminuição da liberação de $\mathrm{H}_{2} \mathrm{O}_{2}$ devido à inativação das NADH desidrogenases externas seja em decorrência dos substratos respiratórios utilizados no ensaio fornecerem elétrons unicamente para a NADH desidrogenase interna (ver discussão em maiores detalhes na seção Super-expressão das NADH desidrogenses).

Conforme anteriormente observado por Busso e colaboradores (2010b), o mutante $\Delta$ coq10 produziu elevados níveis de $\mathrm{H}_{2} \mathrm{O}_{2}$ na presença do inibidor do complexo III antimicina A (Figura 5B). Estes dados novamente confirmam a ideia de que o mutante $\Delta \operatorname{coq} 10$ possui um ciclo $Q$ parcialmente ativo, pois apesar de ocorrer a transferência de elétrons para o citocromo $b \mathrm{~L}$, esse mutante é incapaz de promover a redução do citocromo $c$. A figura $5 B$ demonstra que a inativação individual das $\mathrm{NADH}$ desidrogenases externas assim como a dupla inativação dessas enzimas, não alterou a resposta do mutante $\Delta \operatorname{coq} 10$ a antimicina $A$. Entretanto, do mesmo modo que a linhagem selvagem, a inativação da enzima Ndi1p aboliu completamente a resposta do mutante $\Delta$ coq10 $\Delta$ ndi1 a inibição com antimina A. O mesmo ocorreu para o triplo mutante $\Delta$ coq10 $\Delta$ ndi1 $\Delta$ nde1 $\Delta$ nde2.

Entretanto, contrariamente ao ocorrido para a linhagem selvagem, a

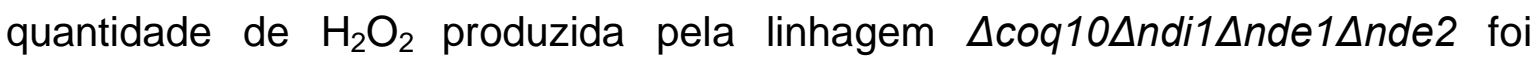
significativamente similar ao mutante simples $\Delta$ coq10. Isto se deve provavelmente a elevada taxa de células petites presentes na população celular utilizada para realizar os experimentos de produção de $\mathrm{H}_{2} \mathrm{O}_{2}$ na linhagem

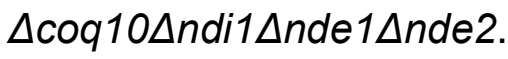

As taxas de liberação de $\mathrm{H}_{2} \mathrm{O}_{2}$ para a linhagem $\Delta c o q 4$, que não sintetiza coenzima $Q$, em combinação com a inativação das NADH desidrogenases também foram avaliadas (Figura $5 \mathrm{C}$ ). Conforme anteriormente reportado, a 
linhagem $\Delta$ coq4 apresentou elevada produção de $\mathrm{H}_{2} \mathrm{O}_{2}$ quando comparada com a linhagem selvagem (BUSSO et al., 2010b). Curiosamente, a taxa de liberação de $\mathrm{H}_{2} \mathrm{O}_{2}$ observado para a linhagem $\Delta \operatorname{coq} 4$ foi significativamente superior a da linhagem $\Delta$ coq10. Tal diferença pode ser em decorrência do grande acúmulo de radicais livres de flavina encontradas nas enzimas NADH e succinato desidrogenase da cadeia respiratória mitocondrial (discutido em maiores detalhes na seção discussão final). De fato, a inativação da enzima Ndi1p, ao qual contem flavina como cofator em seu centro de reação, reduziu significativamente a liberação de $\mathrm{H}_{2} \mathrm{O}_{2}$ a partir das linhagens $\Delta$ coq4 $\Delta$ ndi1 e $\Delta$ coq4 $4 n$ ndi1 $\Delta$ nde1. Entretanto, a inativação das $\mathrm{NADH}$ desidrogenases externas, que também contem flavinas, não diminuiu a taxa de liberação de $\mathrm{H}_{2} \mathrm{O}_{2}$ das linhagens $\Delta$ coq $4 \Delta$ nde1 e $\Delta$ coq $4 \Delta n d e 2$, provavelmente em decorrência dos substratos respiratórios utilizados nos ensaios de liberação de $\mathrm{H}_{2} \mathrm{O}_{2}$ fornecerem elétrons preferencialmente para a enzima Ndi1p (discutido em maiores detalhes na sessão super-exressão das NADH desidrogenases).

De acordo com o esperado a antimicina $A$ não teve nenhum efeito sobre a produção de $\mathrm{H}_{2} \mathrm{O}_{2}$ do mutante $\Delta c o q 4$ (BUSSO et al., 2010b). O mesmo ocorreu para a linhagem $\Delta$ coq4 em combinação com a inativação das NADH desidrogenases. Os resultados confirmam que o mutante $\Delta$ coq4 não apresenta um ciclo $Q$ ativo em decorrência da ausência da coenzima $Q$.

\subsection{Avaliação da estabilidade do mtDNA nas linhagens WT, $\Delta$ coq10 e $\Delta \operatorname{coq} 4$ em combinação com a inativação das NADH desidrogenases mitocondriais}

Após verificarmos as taxas de liberação de $\mathrm{H}_{2} \mathrm{O}_{2}$ nos diferentes mutantes para as NADH desidrogenases mitocondriais, procuramos avaliar os efeitos da inativação dessas enzimas sobre a estabilidade do mtDNA, através de um simples ensaio quantitativo do surgimento de colônias petites em populações de levedura crescendo sobre uma fonte de carbono fermentável. Por meio deste ensaio, a frequência de colônias petites para as linhagens haplóides de WT, $\Delta$ coq10 e $\Delta$ coq4 em combinação com a inativação das NADH desidrogenases mitocondriais foram determinadas. Os resultados estão resumidos na figura 6 . 
Figura 6 - Determinação da estabilidade do DNA mitocondrial (mtDNA).

A

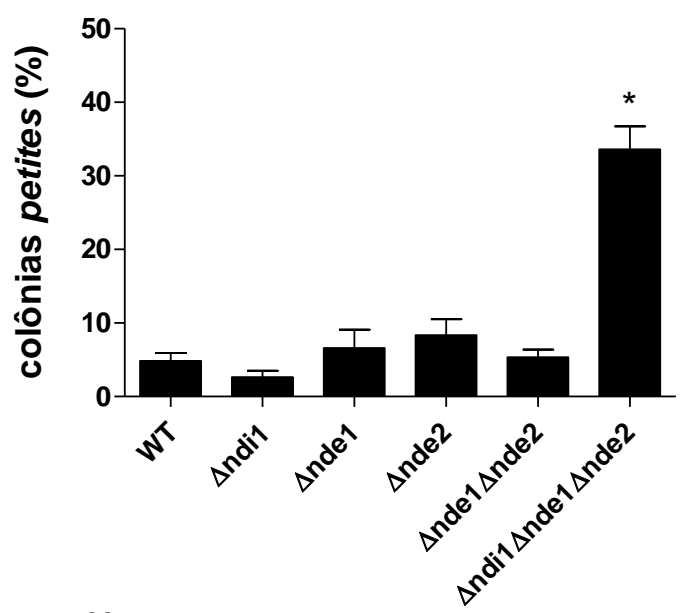

B
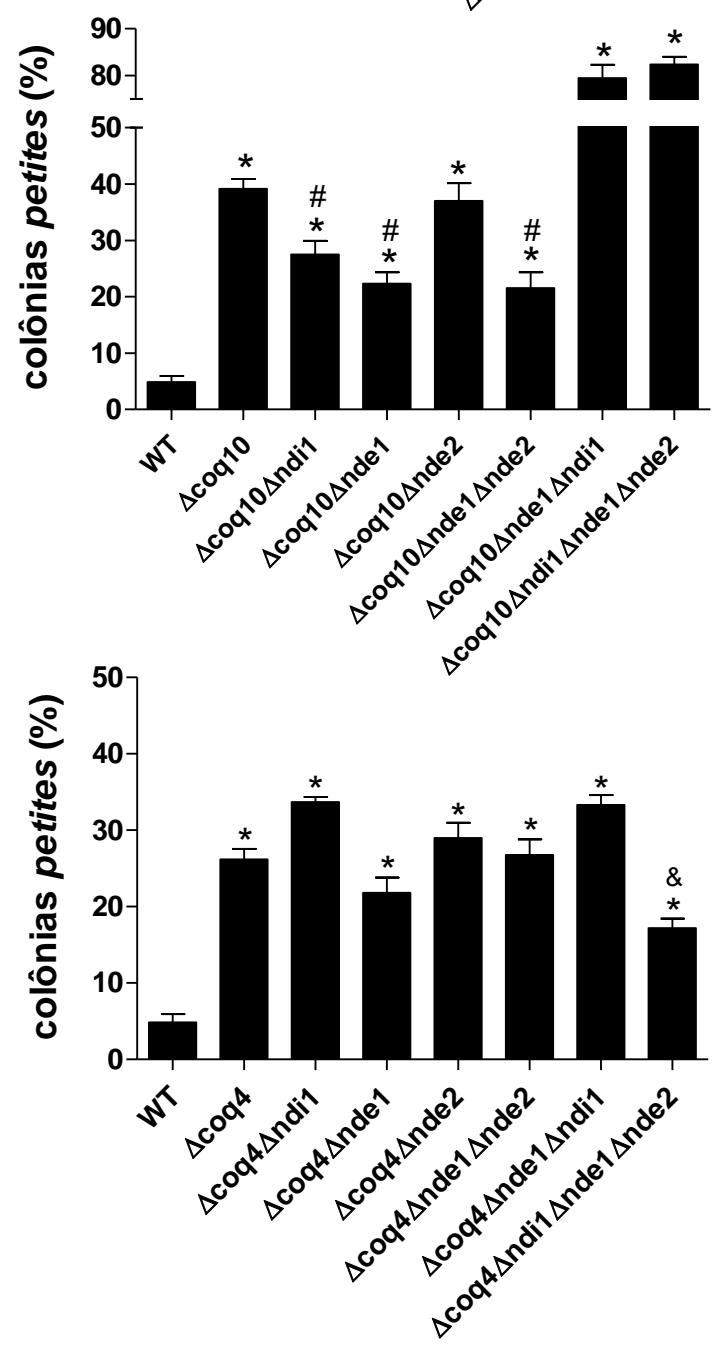

A frequência de formação de colônias petites nas linhagens WT, $\Delta \operatorname{coq} 10$ e $\Delta \operatorname{coq} 4$ em combinação com a inativação das NADH desidrogenases foi realizada conforme descrição em Materiais e Métodos (Item 3.8). ( $\left.{ }^{*}\right) P<0.01$ vs. WT; (\#) $P<0.01$ vs. $\Delta$ coq10; (\&) $P<0.01$ vs. $\Delta \operatorname{coq} 10$. 
A linhagem parental de referência utilizada neste trabalho, W303-1a, apresentou uma frequência de aproximadamente $5 \%$ de colônias petites (Figura 6A). Dimitrov e colaboradores (2009) reportaram uma frequência de surgimento de colônias petites em torno de 10\% para a linhagem W303-1a. Os autores também observaram a existência de uma grande diferença na produção de colônias petites entre as linhagens encontradas na natureza e as linhagens comumente utilizadas em laboratório. Tal variação se deve ao grande número de genes nucleares e seus polimorfismos que afetam a estabilidade do mtDNA. A contínua propagação das linhagens de $S$. cerevisiae nas atividades de laboratório poderia reduzir a seleção para a manutenção da função do genoma mitocondrial (DIMITROV et al., 2009).

Semelhante ao ocorrido para linhagem selvagem, os mutantes simples das $\mathrm{NADH}$ desidrogenases mitocondriais, assim como o duplo mutante $\Delta n d e 1 \Delta n d e 2$, produziram quantidades relativamente baixas de colônias petites (Figura 6 A). $O$ mesmo não ocorreu para o triplo mutante $\Delta n d i 1 \Delta n d e 1 \Delta n d e 2$, que apresentou uma elevada taxa de petites. Este aumento na produção de petites pode ser em decorrência da maior produção de EROs sugerida pela maior liberação de $\mathrm{H}_{2} \mathrm{O}_{2}$ reportada para o triplo mutante (comparar a figura $5 \mathrm{~A}$ com $6 \mathrm{~A}$ ). Portanto, este é o primeiro indício apresentado neste trabalho de que a elevada produção de EROs desencadeia um aumento na instabilidade do genoma mitocondrial.

De acordo com esta hipótese, a elevada instabilidade do genoma mitocondrial observada no mutante $\Delta \operatorname{coq} 10$, provavelmente em decorrência de uma produção excessiva de EROs, poderia ser restaurada através da eliminação da fonte de elétrons responsáveis pela geração dessas EROs. Conforme esperado, a inativação da enzima Nde1p, a principal responsável pelo fornecimento de elétrons para a coenzima $Q$ em S. cerevisiae (Bunoust et al., 2005) resultou em uma diminuição significativa na geração de colônias petites na linhagem $\Delta \operatorname{coq} 10$ (Figura $5 \mathrm{~B}$ ). A inativação de Ndi1p teve um efeito semelhante, porém em um nível menor do que o ocorrido na ausência de Nde1p. Já a inativação de Nde2p não alterou a produção de petites do mutante $\Delta$ coq10. Curiosamente, a inativação de ambas as NADH externas Nde1p e Nde2p reduziu a produção de petites tal qual ao ocorrido para a linhagem $\Delta$ coq10 $\Delta$ nde1. Analisados em conjunto os resultados indicam que as enzimas Nde1p Ndi1p são 
as principais responsáveis pela elevada instabilidade do mtDNA no mutante $\Delta \operatorname{coq} 10$.

Os resultados apresentados sugerem que a diminuição no fornecimento de elétrons para coenzima $Q$ no mutante $\Delta$ coq10, promoveu uma redução na produção de petites. Por outro lado, a interrupção total do fornecimento de elétrons, através da inativação das três NADH desidrogenases, resultou em uma elevada instabilidade do genoma mitocondrial (Figura 5 B). A produção de petites para a linhagem $\Delta$ coq $10 \Delta$ ndi1 $\Delta$ nde1 $\Delta$ nde2 foi de aproximadamente $85 \%$. Curiosamente, a linhagem $\Delta$ coq10 $\Delta$ ndi1 $\Delta$ nde1 também produziu elevada taxa de petites, aproximadamente $80 \%$. Portanto, apesar da inativação individual das enzimas Nde1p e Ndi1p diminuir a produção de petites, a ausência de ambas as enzimas desencadeou elevada instabilidade do mtDNA. Os resultados também indicam que a presença da enzima Nde2p na linhagem $\Delta \operatorname{coq} 10 \Delta n d i 1 \Delta$ nde1 não foi suficiente para evitar a elevada instabilidade do mtDNA. Portanto, podemos concluir que apenas a redução parcial do fornecimento de elétrons para a coenzima $\mathrm{Q}$ no mutante $\Delta \operatorname{coq} 10$ foi capaz de diminuir a produção de petites. $\mathrm{A}$ concomitante inativação da NADH desidrogenase da matriz mitocondrial (Ndi1p) e a forma majoritária da NADH desidrogenase do espaço intermembrana (Nde1p), aumenta a instabilidade do mtDNA.

De maneira contrária ao ocorrido para o mutante $\Delta \operatorname{coq} 10$, a inativação das NADH desidrogenases individuais não reduziu a geração de petites na linhagem $\Delta$ coq4 (Figura $6 \mathrm{C}$ ). Da mesma forma, a ausência de ambas as NADH desidrogenases externas, assim como a inativação de Ndi1p e Nde1p, não alteraram a produção de petites desse mutante. Curiosamente, e contrário ao ocorrido para a linhagem selvagem e o mutante $\Delta$ coq10, a inativação das três NADH desidrogenases reduziu significativamente a produção de petites do mutante $\Delta$ coq4. Portanto, a elevada instabilidade do mtDNA reportada para as linhagens WT e $\Delta$ coq10 sem as $\mathrm{NADH}$ desidrogenases e, portanto, contendo excesso de coenzima $Q$ oxidada, não ocorre na linhagem $\Delta$ coq4 totalmente desprovida de coenzima $Q$. 


\subsection{Super-expressão das NADH desidrogenases nas linhagens WT, $\Delta \operatorname{coq} 10$ e $\Delta \operatorname{coq} 4$.}

Até o momento, reportamos que a elevada instabilidade do mtDNA observada no mutante $\Delta \operatorname{coq} 10$ poderia ser em decorrência da contínua geração de EROs devido o bloqueio parcial do ciclo $Q$ observado na ausência da proteína Coq10p. Conforme já demonstrado, a redução no fornecimento de elétrons para a coenzima $Q$ na linhagem $\Delta$ coq10, reduziu significativamente a geração de colônias petites. Portanto, resolvemos investigar se a super-expressão das NADH desidrogenases promoveria um aumento da instabilidade do mtDNA no mutante $\triangle$ coq10. Para isto, os genes das três NADH desidrogenases mitocondriais (NDI1, NDE1 e NDE2) foram amplificados e clonados em fusão com dois diferentes promotores: o promotor constitutivo TEF1, derivado do gene que codifica para 0 fator de elongação da tradução 1a (MUMBERG et al., 1995) e o promotor induzível GAL10, derivado do gene que codifica para o fator de transcrição induzido pela galactose, GAL 10) (JOHNSTON; DAVIS, 1984). Além da fusão com os promotores de expressão, os genes das NADH desidrogenases foram fusionados com o epítopo para hemaglutinina A (HA) para podermos avaliar a super-expressão das proteínas através de análises de Western Blot. Os plasmídeos resultantes destas clonagens foram então linearizados e em seguida transformados na linhagem $\Delta \operatorname{coq} 10$. O mesmo procedimento foi feito para a linhagem WT.

Para confirmar a elevada expressão das NADH desidrogenases mitocondriais fusionadas com o promotor GAL10, quantidades apropriadas de proteínas mitocondriais foram aplicadas em um gel de SDS-PAGE e em seguida avaliadas através de Western Blot, utilizando anticorpos específicos para a cauda HA fusionadas nessas proteínas. A figura 7 demonstra que os níveis das NADH desidrogenases nas respectivas linhagens super-expressando-as foram significativamente maiores em relação as linhagens com as proteínas controladas pelo promotor selvagem. 
Figura 7 - Super-expressão das NADH desidogenases mitocondriais.
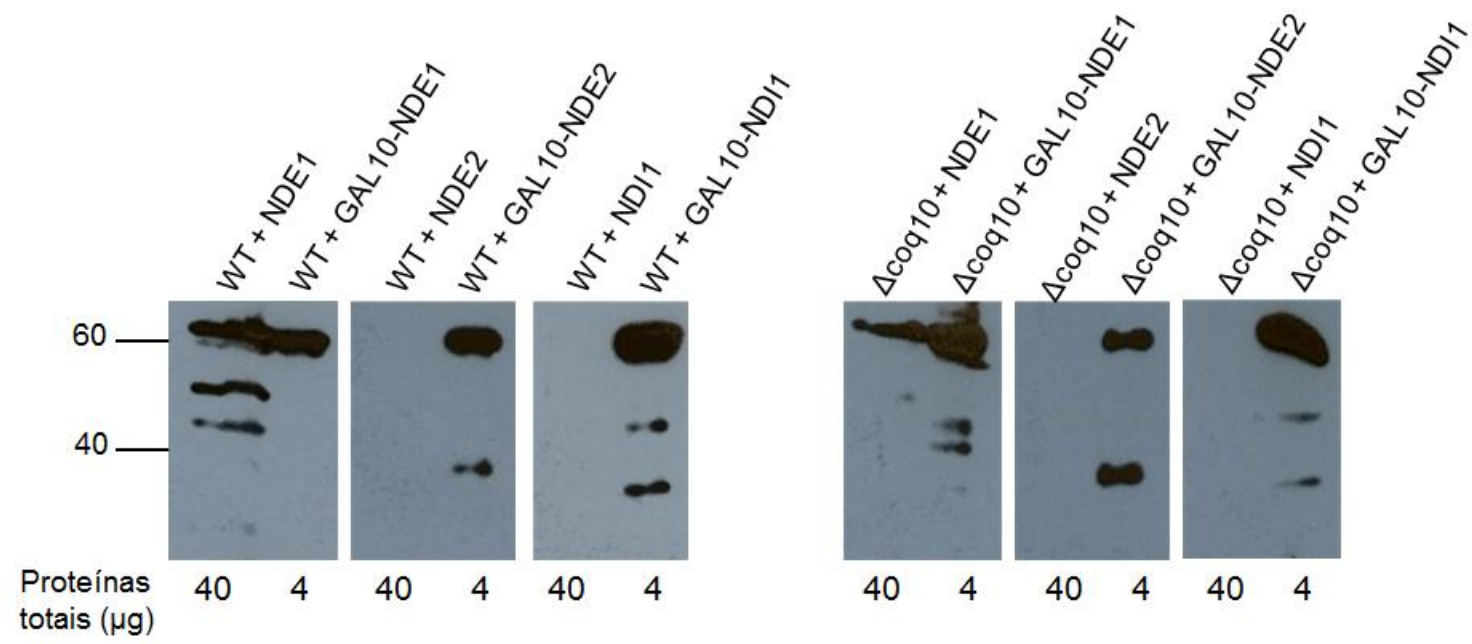

Os níveis de expressão das enzimas NADH desidrogenases nas linhagens WT e $\Delta$ coq10 foram avaliados conforme descrição em Materiais e Métodos (Item 3.11). A quantidade de proteínas mitocondriais carregadas nos géis está indicada na parte inferior da imagem. A imunodetecção das proteínas foi feita através da ligação de um anticorpo específico para o epítopo da hemaglutinina $A$ fusionado nos genes das NADH desidrogenases mitocondriais.

Após verificarmos o aumento na expressão das NADH desidrogenases mitocondriais, procuramos avaliar as propriedades de crescimento das linhagens WT, $\Delta \operatorname{coq} 4$ e $\Delta \operatorname{coq} 10$ super-expressando essas enzimas. A Figura 8 demonstra que a super-expressão das NADH desidrogenases a partir do promotor TEF1 não alterou o crescimento de nenhuma linhagem analisada. Por outro lado, a expressão aumentada da enzima Nde1p a partir do promotor GAL10, causou um severo defeito no crescimento para as linhagens $\Delta \operatorname{coq} 10$ e $\Delta c o q 4$. Tal fenótipo, associado ao fato de que a inativação da enzima Nde1p provocou uma redução na geração de petites do mutante $\Delta$ coq10, instigou a hipótese de que a superexpressão de Nde1p em $\Delta \operatorname{coq} 10$ poderia aumentar a instabilidade do mtDNA dessa linhagem. Portanto, procuramos determinar a taxa de geração de colônias petites nas linhagens WT e $\triangle$ coq10 com expressão aumentada da NADH desidrogenase externa Nde1p. 
Figura 8 - Propriedades de crescimento das linhagens WT, $\Delta c o q 4$ e $\Delta c o q 10$ superexpressando as NADH desidrogenases a partir do promotor TEF1 (Figura A) e GAL10 (Figura B).
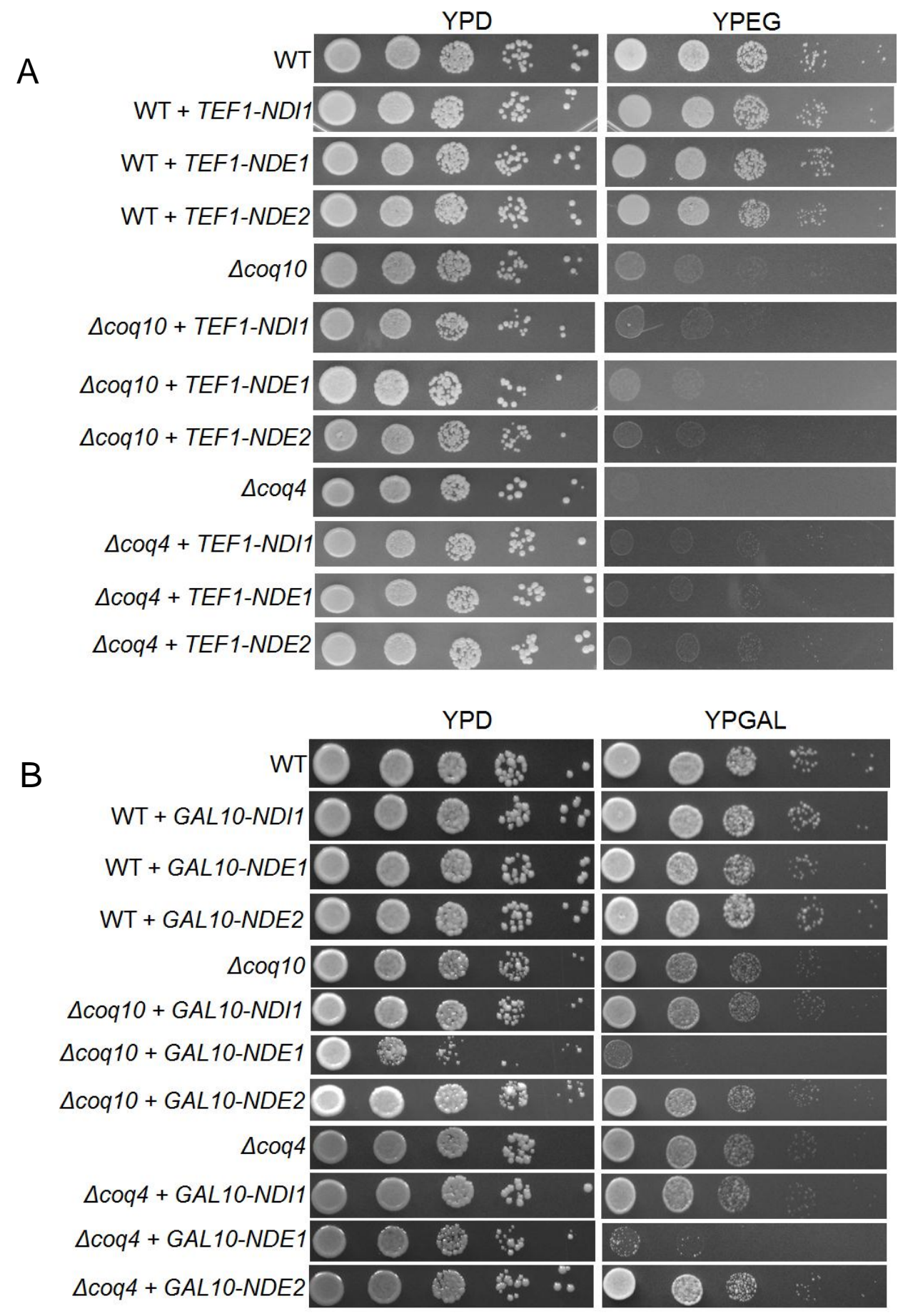

As diferentes linhagens foram crescidas em meio rico YPD (Figura A) e YPGAL (Figura B) por $16 \mathrm{~h}$, e após a absorbância a $600 \mathrm{~nm}\left(\mathrm{Abs}_{600}\right)$ ser ajustada para 1, 0,1, 0,01, 0,001 e 0,0001 , as células foram plaqueadas em placas contendo os respectivos meios de crescimento e em seguida incubadas a $30^{\circ} \mathrm{C}$, por 48 horas. 


\section{Figura 9 - Estabilidade do mtDNA nas linhagens com expressão aumentada} de Nde1p, na presença e ausência da super-expressão de Coq8p.

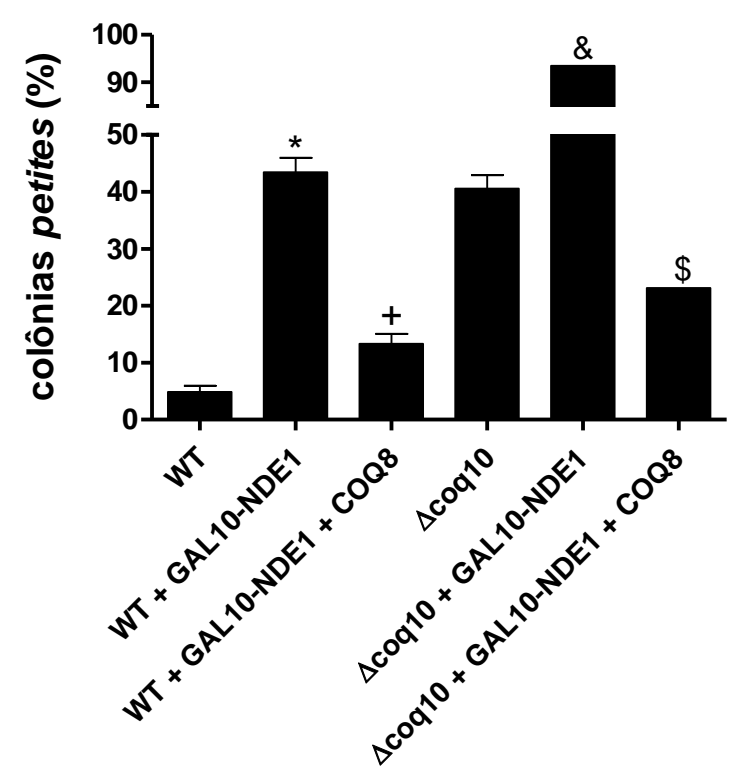

A frequência de formação de colônias petites nas diferentes linhagens foi realizada conforme descrição em Materiais e Métodos (Item 3.8). A indução da expressão da enzima Nde1p a partir do promotor GAL10 foi feita através do crescimento das linhagens em meio YPGAL por um período de 10 horas. ( $\left.{ }^{*}\right) P<0.01$ vs. WT; (+) $P<0.01$ vs. WT+GAL10-NDE1; (\&) $P<0.01$ vs. $\triangle \operatorname{coq} 10 ;(\$) P<0.01$ vs. $\triangle$ coq10+GAL10-NDE1.

Surpreendentemente, apesar da super-expressão de Nde1p a partir do promotor GAL10 não alterar o crescimento da linhagem WT + GAL10-NDE1, ela provocou um aumento significativo na taxa de produção de petites dessa linhagem (Figura 9). Os níveis de produção de petites foram semelhantes ao da linhagem $\Delta$ coq10. Esta última, por sua vez, tornou-se altamente instável, apresentando uma taxa de geração de petites em torno de 95\%. Esses resultados indicam que a expressão aumentada de Nde1p causa elevada instabilidade do genoma mitocondrial. Corroborando essa hipótese medimos a frequência de mutações de ponto no mtDNA nas células com expressão-aumentada de Nde1p utilizando a frequência de resistência a eritromicina (Ery') como um marcador. A resistência a eritromicina é resultante de mutações pontuais nas posições 1050, 1951 e 3993 no gene mitocondrial rRNA 21S (CUI; MASON, 1989; SOR; FUKUHARA, 1984). Este ensaio revelou que a taxa de mutação no mtDNA é 
aproximadamente 3 e 4 vezes maior nas linhagens WT + TEF1-NDE1 e WT + GAL10-NDE1, respectivamente (Figura 10).

Figura 10 - Estimação da taxa de mutação no genoma mitocondrial através da formação de colônias resistentes a eritromicina $\left(\right.$ Ery $\left.^{r}\right)$.

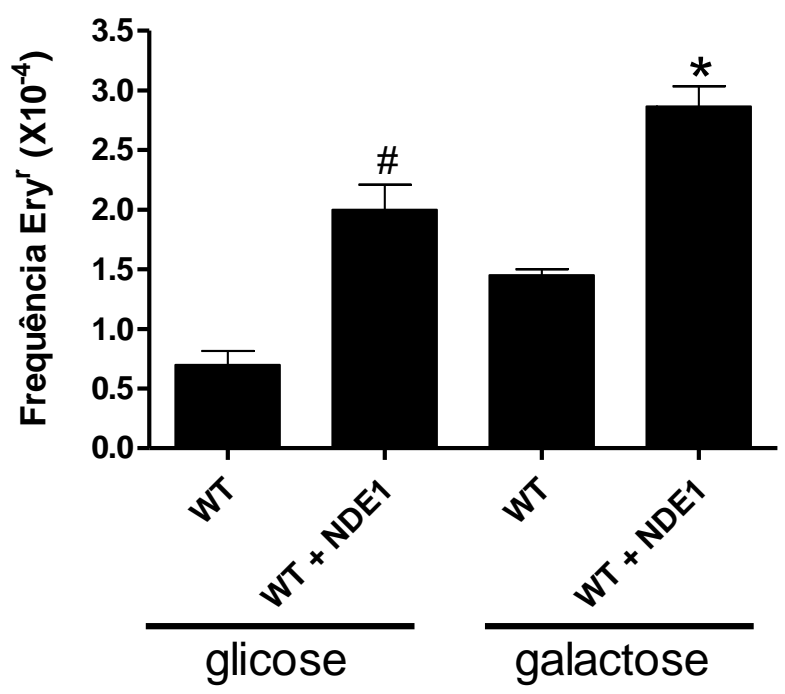

A estimativa da taxa de formação de colônias resistentes a eritromicina foi feito conforme descrito em Materiais e Métodos (Item 3.9). As linhagens WT + NDE1-glicose e WT + NDE1-galactose contém o gene NDE1 fusionado aos promotores TEF1 e GAL10, respectivamente. (\#) $p<0,05$ versus WT glicose. $\left({ }^{*}\right) p<0,05$ versus WT galactose.

$\mathrm{Na}$ tentativa de contornar os efeitos da super-exressão de Nde1p sobre a estabilidade do mtDNA, resolvemos promover um aumento da expressão da proteína Coq8p nas linhagens super-expressando Nde1p. Para isto, estas linhagens foram transformadas com um plasmídeo integrativo contendo o gene COQ8 fusionado no promotor GPD (derivado do gene que codifica para a gliceraldeído-3-fosfato desidrogenase) (ZAMPOL et al., 2010). A escolha de Coq8 foi devido ao fato dessa proteína recuperar parcialmente os defeitos respiratórios apresentados pelo mutante $\Delta \operatorname{coq} 10$ (BARROS et al., 2005). O mecanismo pelo qual isso ocorre parece envolver uma produção aumentada de coenzima $Q$ (BARROS et al., 2005). Recentemente foi demonstrado que Coq8p atua na regulação e na estabilização do complexo de biossíntese da coenzima $\mathrm{Q}$. Na falta 
de um dos constituintes desse complexo, a expressão aumentada de Coq8p parece auxiliar na estabilização do complexo (GIN; CLARK, 2005; XIE et al., 2011; ZAMPOL et al., 2010).

Figura 11 - Propriedades de crescimento das linhagens WT e $\Delta$ coq10 superexpressando a NADH desidrogenase Nde1p a partir do promotor GAL10 com expressão aumentada da proteína Coq8p.

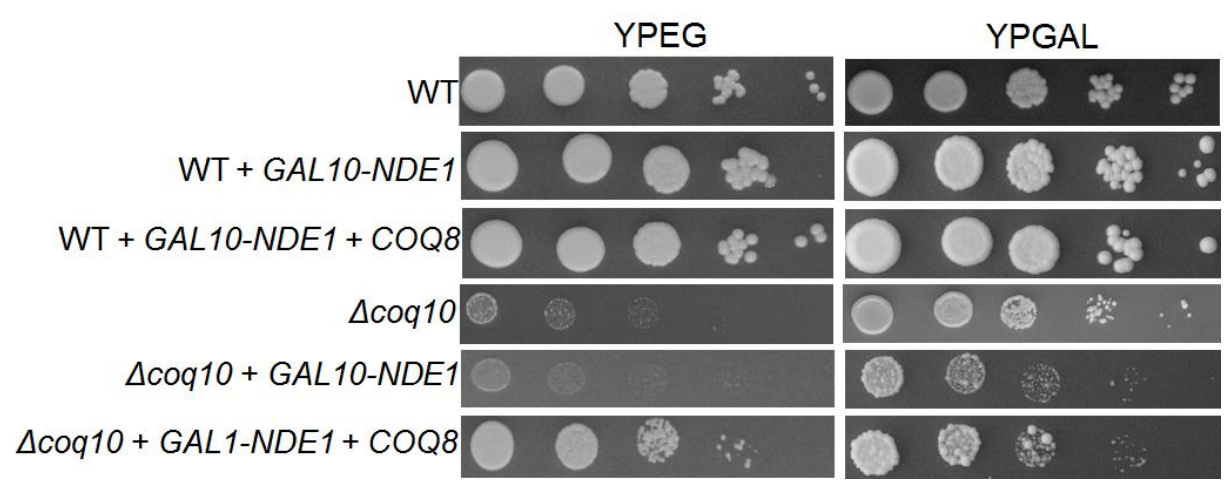

As diferentes linhagens foram crescidas em meio rico YPGAL por $16 \mathrm{~h}$, e após a absorbância a $600 \mathrm{~nm}\left(\mathrm{Abs}_{600}\right)$ ser ajustada para 1, 0,1, 0,01, 0,001 e 0,0001, as células foram plaqueadas em placas contendo os respectivos meios de crescimento e em seguida incubadas a $30 \stackrel{\circ}{ } \mathrm{C}$. O período de incubação consistiu em 72 horas.

Conforme esperado, a expressão aumentada de Coq8 recuperou a estabilidade do DNA mitocondrial nas linhagens super-expressando Nde1p (Figura 9), como também melhorou o crescimento do mutante $\Delta$ coq10 superexpressando Nde1p (Figura 11).

Por outro lado, os ensaios de liberação de $\mathrm{H}_{2} \mathrm{O}_{2}$ demonstram que a expressão aumentada de Nde1p na linhagem selvagem não aumentou a taxa de produção de $\mathrm{H}_{2} \mathrm{O}_{2}$. O mesmo ocorreu para a linhagem $\Delta$ coq10. No entanto, a análise da Figura 12 nos mostra que a linhagem $\Delta$ coq10 com expressão aumentada da NADH desidrogenase externa Nde1p, não respondeu a adição de antimicina $A$, refletindo o grande número de colônias petites geradas na cultura utilizada na preparação mitocondrial. 
Figura 12 - Medidas da liberação de peróxido de hidrogênio $\left(\mathrm{H}_{2} \mathrm{O}_{2}\right)$ em mitocôndrias isoladas a partir das linhagens com super-expressão da enzima Nde1p.

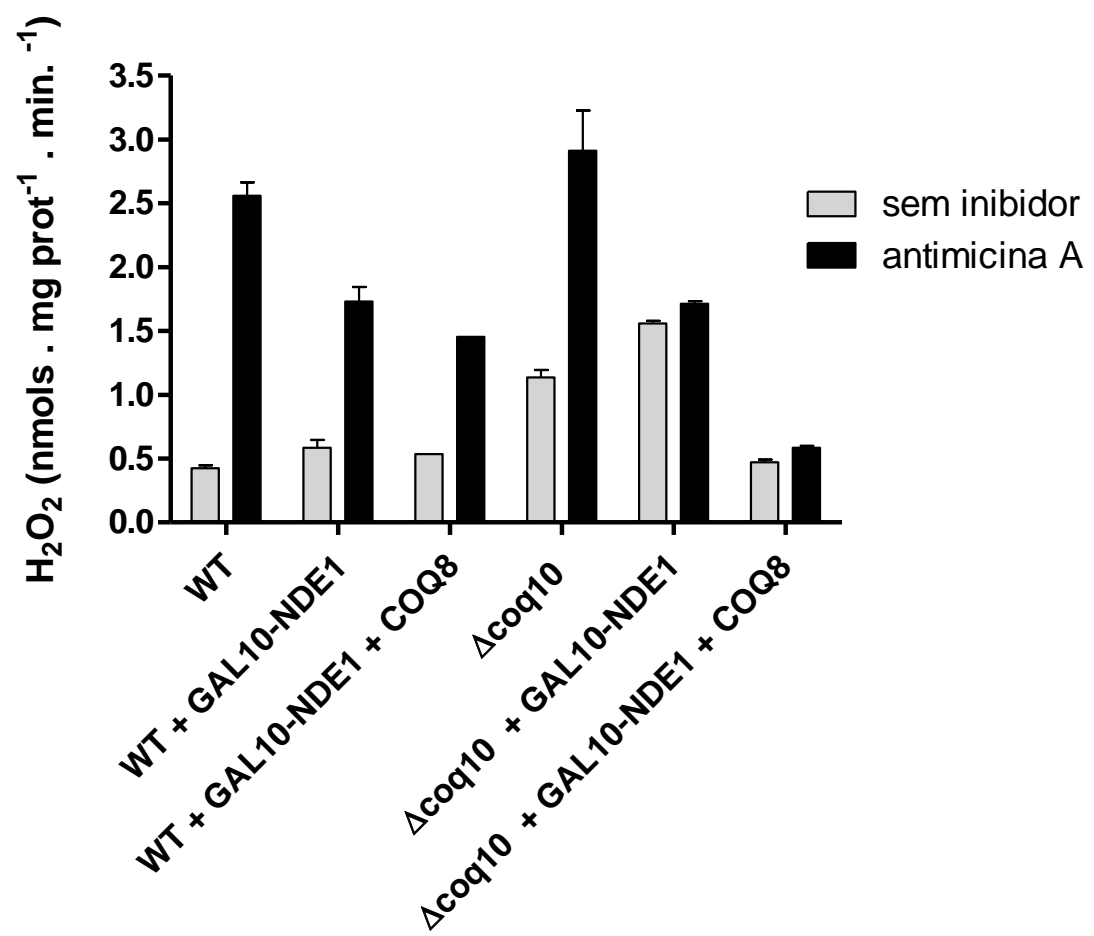

A determinação da liberação de $\mathrm{H}_{2} \mathrm{O}_{2}$ em suspensões mitocondriais $(100 \mu / \mathrm{mL})$ induzida por etanol $2 \%$, glutamato $1 \mathrm{mM}$ e malato $1 \mathrm{mM}$, foi realizada conforme descrito em Materiais e Métodos (Item 3.13).

Além da elevada porcentagem de colônias petites observada nas culturas utilizadas para a extração das mitocôndrias, outro importante fator merece atenção na interpretação dos resultados de produção de $\mathrm{H}_{2} \mathrm{O}_{2}$. Durante os ensaios de liberação de $\mathrm{H}_{2} \mathrm{O}_{2}$, os substratos respiratórios utilizados para ativar a cadeia respiratória mitocondrial foram: malato $1 \mathrm{mM}$, glutamato $1 \mathrm{mM}$ e etanol $2 \%$. Malato e glutamato são substratos respiratórios metabolizados na matriz mitocondrial. A oxidação do malato é catalisada pela enzima malato desidrogenase enquanto o glutamato é oxidado pela glutamato desidrogenase (NELSON; COX, 2009). Ambas as reações produzem NADH, que é posteriormente oxidado pela NADH desidrogenase interna Ndi1p para reduzir a ubiquinona (BAKKER et al., 2001). Portanto, devido as NADH desidrogenases externas apresentarem os sítios ativos voltados para o espaço intermembrana 
(BAKKER et al., 2001), apenas Ndip está envolvida no acoplamento da oxidação dos substratos malato e glutamato com a cadeia respiratória.

O etanol que também foi utilizado como um substrato respiratório, pode ser oxidado por no mínimo três isoenzimas da álcool desidrogenase: 2 citosólicas, codificadas pelos genes $A D H 1$ e $A D H 2$, e uma mitocondrial, codificada pelo gene $A D H 3$ (BAKKER et al., 2000). Enquanto Adh1p está envolvida principalmente na fermentação alcoólica (BAKKER et al., 2000), Adh2 possui elevada afinidade pelo etanol e parece ser a principal responsável pela sua degradação (GANZHORN et al., 1987). Sendo assim, o NADH gerado durante a oxidação do etanol pela enzima Adh2 citosólica poderia ser oxidado pelas NADH desidrogenases externas. No entanto, durante o procedimento de isolamento das mitocôndrias as enzimas citosólicas foram perdidas e, portanto, não estavam presentes nos ensaios de liberação de $\mathrm{H}_{2} \mathrm{O}_{2}$. Isto poderia explicar a ausência de uma produção aumentada de $\mathrm{H}_{2} \mathrm{O}_{2}$ nas mitocôndrias isoladas da linhagem selvagem superexpressando a enzima Nde1p. O mesmo se aplica para o mutante $\Delta \operatorname{coq} 10$ apresentando a inativação das $\mathrm{NADH}$ desidrogenases externas, ao qual não apresentou uma diminuição na taxa de liberação de $\mathrm{H}_{2} \mathrm{O}_{2}$ (ver Figura $5 \mathrm{~B}$ ), .

Para contornar este problema, utilizamos o NADH como substrato respiratório, ao qual pode ser oxidado diretamente pela mitocôndria de $S$. cerevisiae através das NADH desidrogenases externas (LUTTIK et al., 1998). A ressalva quanto a utilização do NADH como substrato respiratório nos ensaios de liberação de $\mathrm{H}_{2} \mathrm{O}_{2}$ é decorrente da sua interferência com o Amplex Red quando

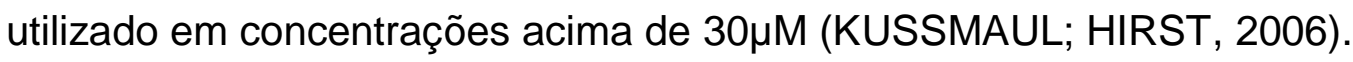

A Figura 13 demonstra que inativação da enzima Nde1p reduziu significativamente a taxa de liberação de peróxido de hidrogênio das linhagens WT e $\Delta$ coq10. Estes resultados sugerem que a NADH desidrogenase externa 1 , localizada na superfície externa da membrana mitocondrial interna, é uma importante fonte de produção de peróxido de hidrogênio. 
Figura 13 - Medidas da liberação de peróxido de hidrogênio $\left(\mathrm{H}_{2} \mathrm{O}_{2}\right)$ em mitocôndrias isoladas a partir das linhagens com inativação da enzima Nde1p.

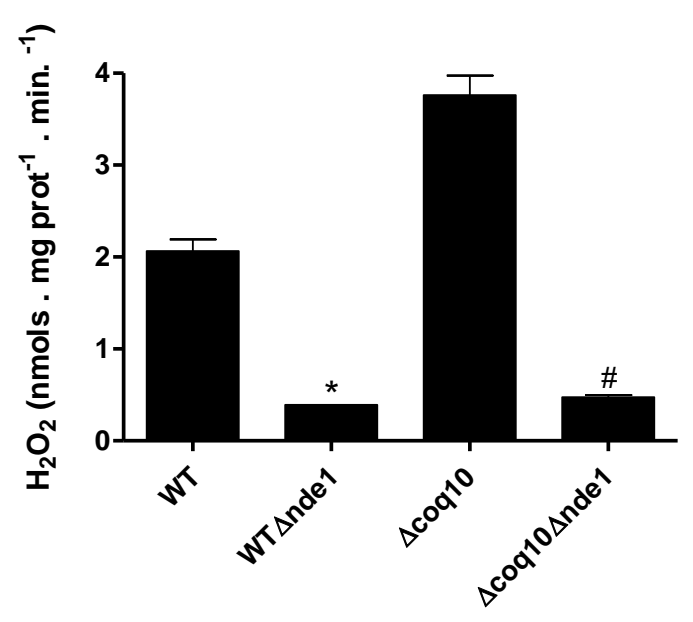

A determinação da liberação de $\mathrm{H}_{2} \mathrm{O}_{2}$ em suspensões mitocondriais $(100 \mu / \mathrm{mL})$ induzida $\mathrm{NADH} 30 \mu \mathrm{M}$, foi realizada conforme descrito em Materiais e Métodos (Item 3.13). 


\section{DISCUSSÃO FINAL}

Nos últimos anos, tem-se postulado que a disfunção mitocondrial e o dano no mtDNA desempenham uma função central em muitas patologias humanas e estão intimamente relacionadas com os processos de envelhecimento (WALLACE, 2005). Os resultados apresentados nessa dissertação reforçam esse conceito. $O$ bloqueio da transferência de elétrons mitocondrial, devido a mutações em genes do sistema de fosforilação oxidativa, aumenta a produção basal de EROs e consequentemente causa sérios danos nos constituintes celulares, incluindo lipídeos, proteínas e DNA (BENTINGER et al., 2007). Em particular, os danos provocados no mtDNA representam um sério risco para a atividade mitocondrial, uma vez que o genoma mitocondrial codifica subunidades essenciais do sistema de fosforilação oxidativa. O resultado final é uma alça de alimentação positiva entre produção aumentada de EROs e mutações no mtDNA (TRACHOOTHAM et al., 2009). Todavia, essa situação é contornada em $S$. cerevisiae, pois, sendo um aeróbico facultativo, mutações no mtDNA e eventuais danos oxidativos alimentam a perda de segmentos inteiros do DNA mitocondrial, gerando células $r h 0^{-}$e $r h 0^{\circ}$. Estas apresentam menor geração de EROs pela simples perda do complexo III, um importante centro de vazamento de elétrons.

Neste trabalho procuramos determinar as causas da elevada instabilidade do mtDNA gerada em decorrência do bloqueio da transferência de elétrons mitocondrial pela coenzima Q. Para isto, centramos nossos esforços em dois mutantes de $S$. cerevisiae que apresentam defeitos distintos no metabolismo da coenzima Q: o mutante $\Delta c o q 4$, ao qual é incapaz de sintetizar coenzima $\mathrm{Q}$, em decorrência da deleção do gene que codifica Coq4p (BELOGRUDOV et al., 2001) e o mutante $\Delta \operatorname{coq} 10$, que sintetiza coenzima $\mathrm{Q}$ em níveis próximo ao da linhagem selvagem, mas é incapaz de dar prosseguimento a cadeia respiratória (BARROS et al., 2005; BUSSO et al., 2010b).

As medidas de liberação de peróxido de hidrogênio $\left(\mathrm{H}_{2} \mathrm{O}_{2}\right)$ revelaram que a mitocôndria do mutante $\Delta$ coq4 teve uma alta taxa basal de produção de EROs. Durante a respiração mitocondrial a coenzima $Q$ recebe elétrons de diferentes coenzima $Q$ oxidorredutases e em seguida os transferem para o complexo III, que por sua vez promove a redução do citocromo $c$ (HATEFI, 1985). Na ausência da coenzima $Q$, todos os carregadores de elétrons localizados a sua montante 
tornam-se completamente reduzidos. Sob estas condições, a reação do oxigênio molecular com moléculas de flavinas (FMN) presentes no complexo I de mamíferos, gera grandes quantidades de radical superóxido (ST-PIERRE et al., 2002; KUSSMAUL; HIRST, 2006; HIRST et al., 2008). As diferentes coenzima Q oxidorredutases de $S$. cerevisiae, apesar de serem evolutivamente distintas do complexo I de mamíferos, também contém FMN e desta forma poderiam favorecer a produção de $\mathrm{H}_{2} \mathrm{O}_{2}$ (DAVIDSON; SCHIESTL, 2001).

De acordo com esta hipótese, a remoção da fonte de elétrons para a cadeia respiratória poderia aliviar o estresse oxidativo causado pelo bloqueio da cadeia respiratória. De fato, a inativação da enzima Ndip reduziu significativamente a produção de $\mathrm{H}_{2} \mathrm{O}_{2}$ das mitocôndrias isoladas das linhagens $\Delta c o q 4 \Delta n d i 1$ e $\Delta c o q 4 \Delta n d i 1 \Delta n d e 1$, quando comparadas com $\Delta$ coq4. A inativação das NADH desidrogenases externas não teve o mesmo efeito provavelmente em decorrência dos substratos respiratórios utilizados nos ensaios fornecerem elétrons unicamente para a enzima Ndi1p (ver discussão mais detalhada na sessão super-expressão das NADH desidrogenases). Por outro lado, a inativação de Ndip não reduziu a produção basal de mutantes petites da linhagem $\Delta$ coq4. Portanto, para a linhagem com deficiência na síntese da coenzima $Q$, a redução na produção de EROs não alterou a estabilidade do mtDNA.

Semelhante à linhagem $\Delta c o q 4$, o mutante $\Delta$ coq10 também apresenta um bloqueio na cadeia respiratória mitocondrial. Entretanto, o bloqueio não ocorre devido à ausência da coenzima $Q$ e sim por um defeito na oxidação dessa molécula em decorrência de um ciclo Q parcialmente ativo (BARROS et al., 2005; BUSSO et al., 2010). Utilizando inibidores específicos para o complexo respiratório III, Busso e colaboradores (2010b) demonstraram que o mutante $\Delta$ coq10 é capaz de transferir um elétron do citocromo $b \mathrm{~L}$ para a coenzima $\mathrm{Q}$ ligada no sítio $P$. Entretanto, apesar de ocorrer a transferência de elétrons para o citocromo $b \mathrm{~L}$, há um bloqueio na transferência para a proteína ferro enxofre de Rieske. Desta forma, no mutante $\Delta \operatorname{coq} 10$ os elétrons não chegam ao citocromo $c$, mas continuam a ciclar pelo complexo III.

Devido o mutante $\Delta c o q 10$ ser capaz de transferir elétrons para o citocromo bL, o complexo III pode ser o principal responsável pela produção de EROs nessa linhagem. Suportando esta ideia, as análises de liberação $\mathrm{H}_{2} \mathrm{O}_{2}$ revelaram que o 
mutante $\Delta$ coq10 é responsivo ao inibidor do complexo III antimicina A. A maioria do radical superóxido produzida pelo complexo III resulta da reação entre o oxigênio molecular e a ubisemiquinona produzida durante o ciclo Q (MULLER et al., 2004). De fato, Busso e colaboradores (2010b) reportaram que tanto a linhagem WT quanto o mutante $\Delta \operatorname{coq} 10$, acumularam o radical semiquinona. Apesar de haver indícios de que o complexo III é o principal responsável pela elevada produção basal de EROs no mutante $\Delta$ coq10, as coenzimas $Q$ oxidorredutases também podem estar desempenhando um papel significativo nessa produção. No entanto, a contribuição dessas enzimas para a produção de EROs poderia ser de maneira indireta, atuando apenas como fornecedoras de elétrons para a geração de EROs. Curiosamente, o mutante $\Delta$ coq10 apresentou índices de liberação de $\mathrm{H}_{2} \mathrm{O}_{2}$ inferior ao mutante $\Delta c o q 4$. Enquanto a liberação de $\mathrm{H}_{2} \mathrm{O}_{2}$ derivada da dismutação do radical superóxido no mutante $\Delta$ coq10 ocorre principalmente no espaço intermenbrana, através do vazamento de elétrons a partir do citocromo bL e da enzima Nde1p, no mutante $\Delta c o q 4$ há essencialmente vazamento a partir das enzimas Ndip e Nde1p. Imagina-se que a matriz mitocondrial tenha melhores condições de remover EROs do que o espaço intermembranas pela simples análise comparativa do conjunto de enzimas antioxidantes presentes nos dois compartimentos.

Em resumo, as análises de geração de petites associados com os ensaios de liberação de peróxido de hidrogênio leva-nos a concluir que o principal causador da elevada instabilidade do mtDNA no mutante $\Delta$ coq10 é a continua produção de espécies reativas de oxigênio em decorrência de um defeito no ciclo Q. A constante produção de EROs no mutante $\Delta$ coq10 poderia provocar danos constantes no mtDNA ocasionando uma elevada instabilidade do genoma mitocondrial. A retirada da fonte de elétrons da cadeia respiratória provocou uma diminuição na produção de petites do mutante $\Delta \operatorname{coq} 10$, conforme observado para as linhagens $\Delta \operatorname{coq} 10 \Delta n d e 1, \Delta \operatorname{coq} 10 \Delta$ ndi1 e $\Delta \operatorname{coq} 10 \Delta$ nde $1 \Delta n d e 2$. Por outro lado, a expressão aumentada da principal fornecedora de elétrons para a cadeia respiratória mitocondrial, a enzima Nde1p, aumentou a produção basal de petites.

Apesar da super-expressão gênica ser uma etapa fundamental na determinação da função de uma proteína, esta ferramenta tem sido pouco utilizada para os estudos de estabilidade do mtDNA (CONTAMINE; PICARD, 
2000). Os resultados aqui apresentados demonstram que a super-expressão das enzimas responsáveis pelo lançamento de elétrons para a cadeia respiratória mitocondrial resulta em elevada instabilidade do mtDNA. 


\section{CONCLUSÕES}

1- A maior instabilidade do mtDNA no mutantes $\Delta$ coq10 está relacionada ao estado de oxidação da coenzima $Q$, pois a ausência de agentes oxidorredutores diminuiu a instabilidade, enquanto o excesso aumentou.

2- A correlação entre EROs e instabilidade do mtDNA é prejudicada pelo fato das EROs gerar células rho e rho ${ }^{0}$, as quais, por sua vez, produzem menos EROs, simplesmente por não conter o complexo III ativo. 


\section{REFERÊNCIAS}

ASHBY, M. N.; KUTSUNAI, S. Y.; ACKERMAN, S.; TZAGOLOFF, A.; EDWARDS, P.A. COQ2 is a candidate for the structural gene encoding para-hydroxybenzoate: polyprenyltransferase. J. Biol. Chem., v. 267, p. 4128-4136, 1992.

BABCOCK, M.; DE SILVA, D.; OAKS, R.; DAVIS-KAPLAN, S.; JIRALERSPONG, S.; MONTERMINI, L.; PANDOLFO, M.; KAPLAN. J. Regulation of mitochondrial iron accumulation by Yfh1p, a putative homolog of frataxin. Science, v. 276, p. 1709-1712, 1997.

BAI, Y.; HÁJEK, P.; CHOMYN, A.; CHAN, E.; SEO, B. B.; MATSUNO-YAGI, A.; YAGI, T.; ATTARDI, G. Lack of complex I activity in human cells carrying a mutation in mtDNA-encoded ND4 subunit is corrected by the Saccharomyces cerevisiae NADH-quinone oxidoreductase (ND/1) gene. J. Bio. Chem., v. 276, p. 38808-38813, 2001.

BAKKER, B. M.; BRO, C.; KÖTTER, P.; LUTTIK, M. A. H.; VAN DIJKEN, J. P.; PRONK, J. T. The mitochondrial alcohol dehydrogenase Adh3p is involved in a redox shuttle in Saccharomyces cerevisiae. J. Bacteriol., v. 182, p. 4730-4737, 2000 .

BAKKER, B. M.; OVERKAMP, K. M.; VAN MARIS, A. J. A.; KÖTTER, P.; LUTTICK, M. A. H.; VAN DIJKEN, J. P.; PRONK, J. T. Stoichiometry and compartmentation of NADH metabolism in Saccharomyces cerevisiae. FEMS Microb. Rev., v. 25, p.15-37, 2001.

BALABAN, R. S.; NEMOTO, S.; FINKEL, T. Mitochondria, oxidants, and aging. Cell, v. 120, 483-495, 2005.

BARRIENTOS, A. Yeast models of human mitochondrial diseases. IUBMB Life. v. 55, p. 83-95, 2003.

BARROS, M. H.; JOHNSON, A.; GIN, P.; MARBOIS, B. N.; CLARKE, C. F.; TZAGOLOFF, A. The Saccharomyces cerevisiae COQ10 gene encodes a START domain protein required for function of coenzyme $Q$ in respiration. J. Biol. Chem., v. 280 , p. $42627-42635,2005$.

BELOGRUDOV, G. I.; LEE, P. T.; JONASSEN, T.; HSU, A. Y.; GIN, P.; CLARKE, C. F. Yeast COQ4 encodes a mitochondrial protein required for coenzyme $Q$ synthesis. Arch Biochem Biophys., v. 392, p. 48-58, 2001.

BUNOUST, O.; DEVIN, A.; AVÉRET, N.; CAMOUGRAND, N.; RIGOULET, M. Competition of electrons to enter the respiratory chain: a new regulatory mechanism of oxidative metabolism in Saccharomyces cerevisiae, J. Biol. Chem., v. 280, p. 3407-3413, 2005.

De acordo com:

ASSOCIAÇÃO BRASILEIRA DE NORMAS TÉCINAS. NBR 6023: Informação e documentação: referências: elaboração. Rio de Janeiro, 2002. 
BUSSO, C.; BLEICHER, L.; FERREIRA-JÚNIOR, J. R.; BARROS, M. H. Sitedirected mutagenesis and structural modeling of Coq10p indicate the presence of a tunnel for coenzyme $Q_{6}$ binding. FEBS Lett., v. 584, p. 1609-1614, 2010a.

BUSSO, C.; TAHARA, E. B.; OGUSUCU, R.; AUGUSTO, O.; FERREIRAJUNIOR, J. R.; TZAGOLOFF, A.; KOWALTOWSKI, A.; BARROS, M. H. Saccharomyces cerevisiae coq10 null mutants are responsive to antimycin $A$. FEBS J., v. 277, p. 4530-4538, 2010 b.

BENTINGER, M., BRISMAR, K., DALLNER, G. The antioxidant role of coenzymeQ. Mitochondrion, v. 7, p. 41-50, 2007.

BENTINGER, M.; TEKLE, M.; DALLNER, G. Coenzyme Q - biosynthesis and functions. Biochem. Biophys. Res. Commun., v. 396, p. 74-79, 2010.

CADENAS, E.; BOVERIS, A.; RAGAN, C. I.; STOPPANI, A. O. Production of superoxide radicals and hydrogen peroxide by $\mathrm{NADH}$-ubiquinone reductase and ubiquinol-cytochrome c reductase from beef-heart mitochondria. Arch. Biochem. Biophys., v. 180, p. 248-257,1977.

CAMPUZANO, V.; MONTERMINI, L.; MOLTÒ, M. D.; PIANESE, L.; COSSÈE, M.; CAVALCANTI, F.; MONROS, E.; RODIUS, F.; DUCLOS, F.; MONTICELLI, A.; ZARA, F.; CAÑIZARES, J.; KOUTNIKOVA, H.; BIDICHANDANI, S. I.; GELLERA, C.; BRICE, A.; TROUILLAS, P.; MICHELE, G. D.; FILLA, A.; FRUTOS, R. D.; PALAU, F.; PATEL, P. I.; DONATO, S. D.; MANDEL, J.-L.; COCOZZA, S.; KOENIG, M.; PANDOLFO. M. Friedreich's ataxia: autosomal recessive disease caused by an intronic GAA triplet repeat expansion. Science, v. 271, p.1423-1427, 1996.

CHEN, X. J.; BUTOW, R. A. The organization and inheritance of the mitochondrial genome. Nat. Genet., v. 6, p. 815-825, 2005.

CHI, N. W.; KOLODNER, R. D. Purification and characterization of MSH1, a yeast mitochondrial protein that binds to DNA mismatches. J. Biol. Chem., v. 269, p. 29984-29992, 1994.

CONTAMINE, V.; PICARD, M. Maintenance and integrity of the mitochondrial genome: a plethora of nuclear genes in the budding yeast. Microbiol. Mol. Biol. Rev., v. 64, p. 281-315, 2000.

CUI, T. Z.; KAVAMUKAI, M. Coq10, a mitochondrial coenzyme Q binding protein, is required for proper respiration in Schizosaccharomyces pombe. FEBS J., v. 276, p. 748-759, 2009.

CUI, Z.; MASON, T. L. A single nucleotide substitution at the rib2 locus of the yeast mitochondrial gene for $21 \mathrm{~S}$ rRNA confers resistance to erythromycin and cold-sensitive ribosome assembly. Curr Genet., v. 16, p. 273-279, 1989. 
DAVIDSON, J. F.; SCHIESTL, R. H. Mitochondrial respiratory electron carriers are involved in oxidative stress during heat stress in Saccharomyces cerevisiae. Mol. Cell Biol., v. 24, p. 8483-8489, 2001.

DE VRIES, S.; MARRES, C. A. M. The mitochondrial respiratory chain of yeast. Structure and biosynthesis and the role in cellular metabolism. Biochim. Biophys. Acta, v. 895, p. 205-239, 1987.

DE VRIES, S.; GRIVEL, L. A. Purification and characterization of a rotenoneinsensitive NADH : Q6 oxidoreductase from mitochondria of Saccharomyces cerevisiae. Eur. J. Biochem., v. 384, p. 176-377, 1988.

DE VRIES, S.; VAN WITZENBURG, R.; GRIVELL, L. A.; MARRES, C. A. M. Primary structure and import pathway of the rotenone-insensitive NADHubiquinone oxidoreductase of mitochondria from Saccharomyces cerevisiae. Eur. J. Biochem., v. 203, p. 587-592, 1992.

DIMITROV, L. N.; BREM, R. B.; KRUGLYAK. L.; GOTTSCHLING, D. E. Polymorphisms in multiple genes contribute to the spontaneous mitochondrial genome instability of Saccharomyces cerevisiae S288C strains. Genetics., v. 183, p. 365-383, 2009.

DOLEZAL, P.; LIKIC, V.; TACHEZY, J.; LITHGOW, T. Evolution of the molecular machines for protein import into mitochondria. Science, v. 313, p. 314-318, 2006.

DOUDICAN, N. A.; SONG, B.; SHADEL, G. S.; DOETSCH. P. W. Oxidative DNA damage causes mitochondrial genomic instability in Saccharomyces cerevisiae. Mol. Cell. Biol., v. 25, p. 5196-5204, 2005.

DRÖSE, S.; BRANDT, U. The mechanism of mitochondrial superoxide production by the cytochrome bc1 complex. J. Biol. Chem., v. 283, p. 21649-21654, 2008.

EPHRUSSI, B.; HOTTINGUER, H.; TAVLITZKI, J. Action de l'acriflavine sur les levures. II. Etude genetique du mutant 'petite colonies'. Ann. Inst. Pasteur., v.79, p. 419-450, 1949.

FALKENBERG, M.; LARSSON, N.G.; GUSTAFSSON, C.M. DNA replication and transcription in mammalian mitochondria. Annu. Rev. Biochem., v. 76, p. 679699, 2007.

FANG, J.; BEATTIE, D. S. External alternative NADH dehydrogenase os Saccharomyces cerevisiae: a potential source of superoxide. Free Radic. Biol. Med., v. 34, p. 478-488, 2003.

FANGMAN, W. L.; HENLY, J. W.; BREWER, B.J. RPO41-independent maintenance of [rho-] mitochondrial DNA in Saccharomyces cerevisiae. Mol. Cell. Biol., v. 10, p. 10-15, 1990. 
FAYE, G.; KUJAWA, C.; FUKUHARA, H. Physical and genetic organization of petite and grande yeast mitochondrial DNA. IV. In vivo transcription products of mitochondrial DNA and localization of $23 \mathrm{~S}$ ribosomal RNA in petite mutants of Saccharomyces cerevisiae. J. Mol. Biol., v. 88, n. 1, p. 185-203, 1974.

FOURY, F.; CAZZALINI, O. Deletion of the yeast homologue of the human gene associated with Friedreich's ataxia elicits iron accumulation in mitochondria. FEBS Lett., v. 411, p. 373-377, 1997.

FOURY, F.; ROGANTI, T.; LECRENIER, N.; PURNELLE, B. The complete sequence of the mitochondrial genome of Saccharomyces cerevisiae. FEBS Lett., v. 440 , p. $325-331,1998$.

FOURY, F.; TALIBI, D. Mitochondrial control of iron homeostasis. A genome wide analysis of gene expression in a yeast frataxin-deficient strain, J. Biol. Chem., v. 276, p. 7762-7768, 2001.

GANZHORN, A. J.; GREEN, D. W.; HERSHEY, A. D.; GOULD, R. M.; PLAPP. B. $\mathrm{V}$. Kinetic characterization of yeast alcohol dehydrogenases. Amino acid residue 294 and substrate specificity. J. Biol. Chem., v. 262, p. 3754-3761, 1987.

GIN, P.; CLARKE, C. F. Genetic evidence for a multi-subunit complex in coenzyme Qbiosynthesis in yeast and the role of the Coq1 hexaprenyl diphosphate synthase, J. Biol. Chem., v. 280, p. 2676-2681, 2005.

GLERUM, D. M.; SHTANKO, A.; TZAGOLOFF, A. Characterization of COX17, a yeast gene involved in copper metabolism and assembly of cytochrome oxidase. J. Biol. Chem., v. 271, p. 14504-14509, 1996.

GRANDIER-VAZEILLE, X.; BATHANY, K.; CHAIGNEPAIN, S.; CAMOUGRAND, N.; STEPHEN, M.; J. SCHMITTER. Yeast mitochondrial dehydrogenases are associated in a supramolecular complex. Biochem., v. 40, p. 9758-9769, 2001.

GREENLEAF, A. L.; KELLY, J. L.; LEHMAN, I. R. Yeast RPO41 gene product is required for transcription and maintenance of the mitochondrial genome. Proc. Natl. Acad. Sci. U. S. A., v. 83, p. 3391-3394, 1986.

HANAHAM, D. Studies on transformation of E. coli with plasmids. J. Mol. Biol., v. 166, p. 157-163, 1983.

HARMAN, D. Aging: a theory based on free radical and radiation chemistry. J. Gerontol., v. 11, p. 298-300, 1956.

HATEFI $\mathrm{H}$. The mitochondrial electron transport and oxidative phosphorylation system. Annu. Rev. Biochem., v. 54, p. 1015-1069, 1985.

HEERINGA, S. F.; CHERNIN, G.; CHAKI, M.; ZHOU, W.; SLOAN, A. J.; JI, Z.; XIE, L. X.; SALVIATI, L.; HURD, T. W.; VEGA-WARNER, V., et al. COQ6 
mutations in human patients produce nephrotic syndrome with sensorineural deafness. J. Clin. In vest., v. 121, p. 2013-2024, 2011.

HERRERO, E.; ROS, J.; BELLÍ, G.; CABISCOL, E. Redox control and oxidative stress in yeast cells. Biochim. Biophys. Acta, v. 1780, p. 1217-1235, 2008.

HESS, D. C.; C. L. MYERS.; C. HUTTENHOWER.; M. A. HIBBS.; A. P. HAYES.; PAW, J.; CLORE, J. J.; MENDOZA, R. M.; LUIS, B. S.; NISLOW, C.; GIAVER, G.; COSTANZO, M.; TROYANSKAYA, O. G.; CAUDY, A. A. Computationally driven, quantitative experiments discover genes required for mitochondrial biogenesis. PLoS Genet., v. 5, p. 1-15, 2009.

HILL, J. E., MYERS, A. M., KOERNER, T. J., TZAGOLOFF, A. Yeast/E. coli shuttle vectors with multiple unique restriction sites. Yeast. v. 2, p. 163-167, 1986.

HIRST, J.; KING, M. S.; PRYDE, K. R. The production of reactive oxygen species. by complex I. Biochem. Soc. Trans., v. 36, p. 976-980, 2008.

HSU, A. Y.; DO, T. Q.; LEE, P. T.; CLARKE, C. F. Genetic evidence for a multisubunit complex in the O-methyltransferase steps of coenzyme $Q$ biosynthesis. Biochim. Biophys. Acta, v. 1484, p. 287-297, 2000.

JOHNSTON, M.; DAVIS, R. W. Sequences that regulate the divergent GAL1GAL10 prometer in Saccharomyces cerevisiae. Mol. Cell. Biol., v. 4, p. 14401448, 1984.

JOHNSTON, M.; RILES, L.; HEGEMAN, J. H. Gene disruption. Methods in Enzimol., v. 250, p. 290-315, 2002.

KAWAMUKAI, M. Biosynthesis and bioproduction of coenzyme Q10 by yeasts and other organisms. Biotechnol. Appl. Biochem., v. 53, p. 217-226, 2009.

KELLY, D. P. AND SCARPULLA, R. C. Transcriptional regulatory circuits controlling mitochondrial biogenesis and function. Genes Dev., v. 18, p. 357-368, 2004.

KOWALTOWSKI, A. J.; SOUZA-PINTO, N. C.; CASTILHO, R. F.; VERCESI, A. E. Mitochondria and reactive oxygen species. Free Radic. Biol. Med., v. 47, p. 333343, 2009.

KRISHNAN, K. J.; GREAVES, L. C.; REEVE, A, K.; TURNBULL, D. The ageing mitochondrial genome. Nucleic Acids Res., v. 35, p. 7399-7405, 2007.

KUCEJ, M.; KUCEJOVA, B.; SUBRAMANIAN, R.; CHEN, X. J.; BUTOW, R. A. Mitochondrialnucleoi ds undergo remodeling in response to metabolic cues. $\mathbf{J}$. Cell Sci., v. 121, p. 1861-1868, 2008. 
KUSSMAUL, L.; HIRST, J. The mechanism of superoxide production by NADH:ubiquinone oxidoreductase (complex I) from bovine heart mitochondria. Proc. Natl. Acad. Sci. U. S. A., v. 103, p. 7607-7612, 2006.

LAEMMLI, D. K. Cleavage of structural proteins during in assembly of the head of bacteriophage T4. Nature, v. 227, p. 680-683, 1970.

LAGIER-TOURENNE, C.; TAZIR, M.; LOPEZ, L. C.; QUINZII, C. M.; ASSOUM, M.; DROUOT, N.; BUSSO, C.; MAKRI, S.; ALI-PACHA, L.; BENHASSINE, T.; et al., ADCK3, an ancestral kinase, is mutated in a form of recessive ataxia associated with coenzyme Q(10) deficiency. Am. J. Hum. Genet., v. 82, p. 661672, 2008.

LARSSON, C.; PÂHLMAN, I. L.; ANSELL, R.; RIGOULET, M.; ADLER, L.; GUSTAFSSON, L. The importance of the glycerol 3-phosphate shuttle during aerobic growth of Saccharomyces cerevisiae. Yeast, v.14, p. 347-357, 1998.

LARSSON, N. G. Somatic mitochondrial DNA mutations in mammalian aging. Ann. Rev. Biochem., v. 79, p. 683-706, 2010.

LENAZ, G.; FATO, R.; FORMIGGINI, G.; GENOVA, M. L. The role of Coenzyme $Q$ in mitochondrial electron transport. Mitochondrion, v. 7S, p. S8-S33, 2007.

LENAZ, G.; GENOVA, M. L. Mobility and function of Coenzyme Q (ubiquinone) in the mitochondrial respiratory chain. Biochim. Biophys. Acta, v. 1787, p. 563-573, 2009.

LILL, R.; MÜHLENHOFF. Iron-sulfur protein biogenesis in eukaryotes: components and mechanisms. Annu. Rev. Cell Dev. Biol., v. 22, p. 457-486, 2006.

LIPINSKI, K. A.; KANIAK-GOLIK, A.; GOLIK, P. Maintenance and expression of the $S$. cerevisiae mitochondrial genome-From genetics to evolution and systems biology. Biochim. Biophys. Acta, v. 1797, p. 1086-1098, 2010.

LOWRY, O. H.; ROSEBROUGH, N. J.; FARR, A. L.; RANDALL, R. J. Protein measurement with the Folin phenol reagent. J. Biol. Chem., v. 193, p. 265-275, 1951.

LUTTIK, M. A. H.; OVERKAMP, K. M.; KÖTTER, P.; DE VRIES, S.; VAN DIJKEN, J. P.; PRONK, J. T. The Saccharomyces cerevisiae NDE1 and NDE2 genes encode separate mitochondrial NADH dehydrogenases catalyzing the oxidation of cytosolic NADH. J. Biol.Chem., v. 273, p. 24529-24534, 1998.

MARBOIS, B.; GIN, P.; FAULL, K. F.; PONN, W. W.; LEE, P. T.; STRAHAN, J.; SHEPHERD, J. N.; CLARKE, C. F. Coq3 and Coq4 define a polypeptide complex in yeast mitochondria for the biosynthesis of Coenzyme Q. J. Biol.Chem., v. 280, p. 20231-20238, 2005. 
MARRES, C. A. M.; DE VRIES, S.; GRIVEL, L. A. Isolation and inactivation of the nuclear gene encoding the rotenone-insensitive internal NADH: ubiquinone oxidoreductase of mitochondria from Saccharomyces cerevisiae. Eur. J. Biochem., v. 195, p. 857-862, 1991.

MCEWEN, J. E.; KO, C.; KLOECKNER-GRUISSEM, B.; POYTON, R. O. Nuclear functions required for cytochrome $\mathrm{C}$ oxidase biogenesis in saccharomyces cerevisiae. characterization of mutants in 34 complementation groups. J. Biol Chem., v. 261, p. 11872-11879, 1986.

MUMBERG, D.; MAILER, R.; FUNK, M. Yeast vectors for the controlled expression of heterologous proteins in different genetic backgrounds. Gene, v. 156, p. 119-122, 1995.

MURPHY, M. P. How mitochondria produce reactive oxygen species. Biochem. J., v. 417, p. 1-13, 2009.

MYERS, A. M.; PAPE, L. K.; TZAGOLOFF, A. Mitochondrial protein synthesis is required for maintenance of intact mitochondrial genomes in Saccharomyces cerevisiae. Embo J., v. 4, p. 2087-2092, 1985.

NELSON, D. L.; M. M. COX. Lehninger Principles of Biochemistry., San Francisco: W. H. Freeman, 2009. [1200 p.]

NOBREGA, F. G.; NOBREGA, M. P.; TZAGOLOFF, A. BCS1, a novel gene required for the expression of functional Rieske iron-sulfur protein in Saccharomyces cerevisiae. EMBO J., v. 11, p. 3821-3829, 1992.

NOSEK, J.; FUKUHARA, H. NADH dehydrogenase subunit genes in the mitochondrial DNA of yeasts. J. Bacteriol., v. 176, p. 5622-5630, 1994.

OHLMEIER, S.; KASTANIOTIS, A. J.; HILTUNEN, J. K.; BERGMANN, U. The yeast mitochondrial proteome, a study of fermentative and respiratory growth. $\mathbf{J}$. Biol. Chem., v. 279, p. 3956-3979, 2004.

PARK, C. B.; LARSSON, N. G. Mitochondrial DNA mutations in disease and aging. J. Cell Biol., v. 193, p. 809-818, (2011).

PERALES-CLEMENTE, E.; BAYONA-BAFALUY, M. P.; PÉREZ-MARTOS, A.; BARRIENTOS, A.; FERNÁNDEZ-SILVA, P.; ENRIQUEZ, J. A. Restauration of eléctron transport without próton pumping in mammalian mitochondria. Proc. Natl. Acad. Sci. U. S. A., v. 105, p. 18735-18739, 2008.

PIERREL, F.; HAMELIN, O.; DOUKI, T.; KIEFFER-JAQUINOD, S.; MÜHLENHOFF, U.; OZEIR, M.; LILL, R.; FONTECAVE, M. Involvement of Mitochondrial Ferredoxin and Para-Aminobenzoic Acid in Yeast Coenzyme $Q$ Biosynthesis. Cell. Chem. Biol., v. 17, p. 449-459, 2010.

QUINZII, C. M.; HIRANO, M. Coenzyme $Q$ and mitochondrial disease. Dev. Disabil. Res. Rev., v. 16, p. 183-188, 2010. 
RIGOULET, M.; MOURIER, A.; GALINIER, A.; CASTEILLA, L.; DEVIN, A. Electron competition process in respiratory chain: Regulatory mechanisms and physiological functions. Arc. Biochem. Biophys., v. 1797, 671-677, 2010.

RUSTIN, P.; VON KLEIST-RETZOW, C.; CHANTREL-GROUSSARD, K.; SIDI, D.; MUNNICH, A.; RÖTIG, A. Effect of idebenone on cardiomyopathy in Friedre ich's ataxia: a preliminary study. Lancet, v. 354, p. 477-479, 1999.

SAMBROOK, J.; FRITSCH, E. F.; MANIATIS. T. Molecular Cloning. A laboratory manual. New York: Cold Spring Harbor, Cold Spring Harbor Laboratory Press, 1989. 3 v.

SARRASTE, M. Oxidative phosphorylation at the fin de siècle. Science, v. 283, p. 1488-1492, 1999.

SCHAFFER, S. W.; SULEIMAN, M. S. Mitochondria: The dynamic organelle. New York: Springer, 2007. 359 p.

SCHIESTL, R. H.; GIETZ, R. D. High efficiency transformation of intact cells using single stranded nucleic acids as a carrier. Curr. Genet., v. 16, p. 339-346, 1989.

SCHULTZ, B. E.; CHAN, S. I. Structures and proton-pumping strategies ofmitochondrial respiratory enzymes. Annu. Rev. Biophys. Biomol. Struct., v. 30, p. 23-65, 2001.

SEO, B. B.; KITAJIMA-IHARA, T.; CHAN, E. K. L.; SCHEFFLER, I. E.; MATSUNO-YAGI, A; YAGI, T. Molecular remedy of complex I defects: rotenoneinsensitive internal NADH-quinone oxidoreductase of Saccharomyces cerevisiae mitochondria restores the NADH oxidase activity of complex I-deficient mammalian cells. Proc. Natl. Acad. Sci. USA., v. 95, p. 9167-9171, 1998.

SEO, B. B.; MATSUNO-YAGI, A; YAGI, T. Modulation of oxidative phosphorylation of human kidney 293 cells by transfection with the internal rotenone-insensitive NADH-quinone oxidoreductase (NDI1) gene of Saccharomyces cerevisiae. Biochim. Biophys. Acta, v. 1412, p. 56-65, 1999.

SMALL, W. C.; MCALISTER-HENN, L. Identification of a cytosolically directed NADH dehydrogenase in mitochondria of Saccharomyces cerevisiae. $\mathbf{J}$. Bacteriol., v. 180, p. 4051-4055, 1998.

SOR, F.; FUKUHARA, H. Erythromycin and spiramycin resistance mutations of yeast mitochondria: nature of the rib2 locus in the large ribosomal RNA gene. Nucleic Acids Res., v.12, p. 8313-8318, 1984.

ST-PIERRE, J.; BUCKINGHAM, J. A.; ROEBUCK, S. J; BRAND, M. D. Topology of superoxide production from different sites in the mitochondrial electron transport chain. J. Biol. Chem., v. 277, p. 44784-44790, 2002. 
SUN, J.; TRUMPOWER, L. Superoxide anion generation by the cytochrome bc1 complex. Arc. Biochem. Biophys., v. 419, p. 198-206, 2003.

TAHARA, E. B.; BARROS, M. H.; OLIVEIRA, G. A.; NETTO, L. E. S.; KOWALTOWSKI, A. J. Dihydrolipoyl dehydrogenase as a source of reactive oxygen species inhibited by caloric restriction and involved in Saccharomyces cerevisiae aging. FASEB J., v. 21, p. 274-283, 2007.

TAIT, S. G.; GREEN, D. R. Mitochondria and cell death: outer membrane permeabilization and beyond. Nat. Moll. Cell Biol., v. 11, p. 621-632, 2010.

TAYLOR, R. W.; TURNBULL, D. M. Mitochondrial DNA mutations in human disease. Nat. Genet., v. 5, p. 389-402, 2005.

TRACHOOTHAM, D.; ALEXANDRE, J.; HUANG, P. Targeting cancer cells by ROS-mediated mechanisms: a radical therapeutic approach? Nat. Rev. Drug Discov., v. 8, p. 579-591, 2009.

TRAN, Y. C.; CLARKE, C. F. Endogenous synthesis of coenzyme $Q$ in eukaryotes. Mitochondrion, v. 7S, p. S62-S71, 2007.

TRIFUNOVIC, A.; WREDENBERG, A.; FALKENBERG, M.; SPELBRINK, J. N.; ROVIO, A. T.; BRUDER, C. E.; BOHLOOLY, Y. M.; GIDLOF, S.; OLDFORS, A.; et al. Premature ageing in mice expressing defective mitochondrial DNA polymerase. Nature., v. 429, p. 417-423, 2004.

TUCKER, E. J.; COMPTON, A. G.; CALVO, S. E.; THORBURN, D. R. The Molecular Basis of Human Complex I Deficiency. IUBMB Life., v. 9, p. 669$677,2011$.

TURUNEN, M.; OLSSON, J.; DALLNER, G. Metabolism and function of coenzyme Q. Biochim. Biophys. Acta, v. 1660, p. 171-199, 2004.

TURRENS, J. F.; ALEXANDRE, A.; LEHNINGER, A. L. Ubisemiquinone is the electron donor for superoxide formation by complex III of heart mitochondria. Arch. Biochem. Biophys., v. 237, p. 408-414, 1985.

TURRENS, J. F. Mitochondrial formation of reactive oxygen species. J. Physiol., v. 552, p. 335-344, 2003.

TZAGOLOFF, A.; AKAI, A.; NEEDLEMAN, R. B. Assembly of the mitochondrial membrane system. Characterization of nuclear mutants of Saccharomyces cerevisiae with defects in mitochondrial ATPase and respiratory enzymes. J. Biol. Chem., v. 250, p. 8228-8235, 1975.

TZAGOLOFF, A.; DIECKMANN, C. L. PET Genes of Saccharomyces cerevisiae. Microbiol. Rev., v. 54, p. 211-225, 1990.

TZAGOLOFF, A. Mitochondria. New York: Plenum Press, 1982. 342 p. 
VANLERBERGHE, G. C.; MCINTOSH, L. Alternative oxidase: from gene to function. Annu. Rev. Plant Physiol. Plant Mol. Biol., v. 48, p. 703-734, 1997.

VEAL. E. A.; DAY, A. M.; MORGAN, B. Hydrogen Peroxide Sensing and Signaling. Moll. Cell., v. 26, p, 1-14, 2007.

VON JAGOW, G.; KLINGENBERG, M. Pathways of hydrogen in mitochondria of Saccharomyces carlsbergensis. Eur. J. Biochem., v. 12, p. 583-592, 1970.

WALLACE, D. C. A mitochondrial paradigm of metabolic and degenerative diseases, aging, and cancer: a dawn for evolutionary medicine. Annu. Rev. Genet., v. 39, p. 359-407, 2005.

WALLACE, D. C.; FAN, W.; PROCACCIO, V. Mitochondrial Energetics and Therapeutics. Annu. Rev. Pathol. Mech. Dis., v. 5, p. 297-348, 2010.

WELLEN, K. E.; THOMPSON, C. B. Cellular Metabolic Stress: Considering How Cells Respond to Nutrient Excess. Mol. Cell., v. 40, p. 323-332, 2010.

WESTERMANN, B. Mitochondrial fusion and fission in cell life and death. Nat. Mol. Cell. Biol., v. 11, p. 872-884, 2010.

WIKSTRÖM, M. K.; BERDEN, J. A. Oxidoreduction of cytochrome $b$ in the presence of antimycin. Biochim Biophys Acta, v. 283, p. 403-420, 1972.

WILSON, R. B.; D. M. ROOF. Respiratory deficiency due to loss of mitochondrial DNA in yeast lacking the frataxin homologue. Nat. Genet., v. 16, p. 352-357, 1997.

WINDE, J. H.; GRIVEL, L. A. Global regulation of mitochondrial biogenesis in Saccharomyces cerevisiae. Progres. Nucleic Acid Res. Mol. Biol., v. 46, p. 5189, 1993.

YAGI, T.; Possibility of transkingdom gene therapy for complex I diseases. Biochim. Biophys Acta, v. 1757, p. 708-714, 2006.

XIE, L. X.; HSIEH, E. J.; WATANABE, S.; ALLAN, C. M., CHEN, J. Y.; TRAN, U. C.; CLARKE, C. F. Expression of the human atypical kinase ADCK3 rescues coenzyme $Q$ biosynthesis and phosphorylation of Coq polypeptides in yeast coq8 mutants. Biochim. Biophys. Acta., v. 1811, p. 348-360, 2011.

ZAMPOL, M. A.; BUSSO, C.; GOMES, F.; FERREIRA-JUNIOR, J. R.; TZAGOLOFF, A.; BARROS, M. H. Over-expression of COQ10 in Saccharomyces cerevisiae inhibits mitochondrial respiration, Biochem. Biophys. Res. Commun., v. 402 , p. $82-87,2010$.

ZHOU, M.; DIWU, Z.; PANCHUK-VOLOSHINA, N.; HAUGLAND, R. P. A stable nonfluorescent derivative of resorufin for the fluorometric determination of trace 
hydrogen peroxide: applications in detecting the activity of phagocyte NADPH oxidase and other oxidases. Anal. Biochem., v. 253, p. 162-168, 1997. 